\title{
SEMÁFORO: GRUPO FOCAL CONVENCIONAL X GRUPO FOCAL COM INFORMAÇÃO DO TEMPO DE VERDE/VERMELHO RESTANTE
}

\begin{abstract}
Dissertação apresentada à Escola de Engenharia de São Carlos, da Universidade de São Paulo, como parte dos requisitos para a obtenção do título de Mestre em Ciências, Programa de Pós-graduação em Engenharia de Transportes. Área de concentração: Planejamento e operações de Sistema de Transportes
\end{abstract}

Orientador: Prof. Titular Antonio Clóvis Pinto Ferraz 
AUTORIZO A REPRODUÇĀO E DIVULGAÇĀO TOTAL OU PARCIAL DESTE TRABALHO, POR QUALQUER MEIO CONENCIONAL OU ELETRÓNICO, PARA FINS DE ESTUDO E PESQUISA, DESDE QUE CITADA A FONTE.

Ficha catalográfica preparada pela Seç̃o de Tratamento da Informaçấo do Serviço de Biblioteca - EESC/USP

Spiqolon, Luciana Maria Casparelo

Sembiforo: grupo focsl convencionsl $\times$ grupo focal com informscäo do tempo de verde/vermelho restante / Luc1ana Maria Casparelo Splgolon; orientador Antonio Clóvis P1nto Ferraz. - säo Carlos, 2010.

D1ssertação (Mostrado-Proprama de Pós-Craduação em Engenharia de Transportes e firea de Concentração em planejamento e Operaçóses do sistena de Iransporte) Escola de Engenharia de são Carlos da Universidade de são Paulo, 2010.

1. Sistema de controle de trifeqo. 2. Interseçöes de ruas - capacidade. 3. Trafego - segurança. 4. Grupo focal. 5. Acidentes. I. Titulo. 


\section{FOLHA DE JULGAMENTO}

Candidato(a): Tecnólogo LUCIANA MARIA GASPARELO SPIGOLON.

Dissertação defendida e julgada em 09/12/2010 perante a Comissão Julgadora:
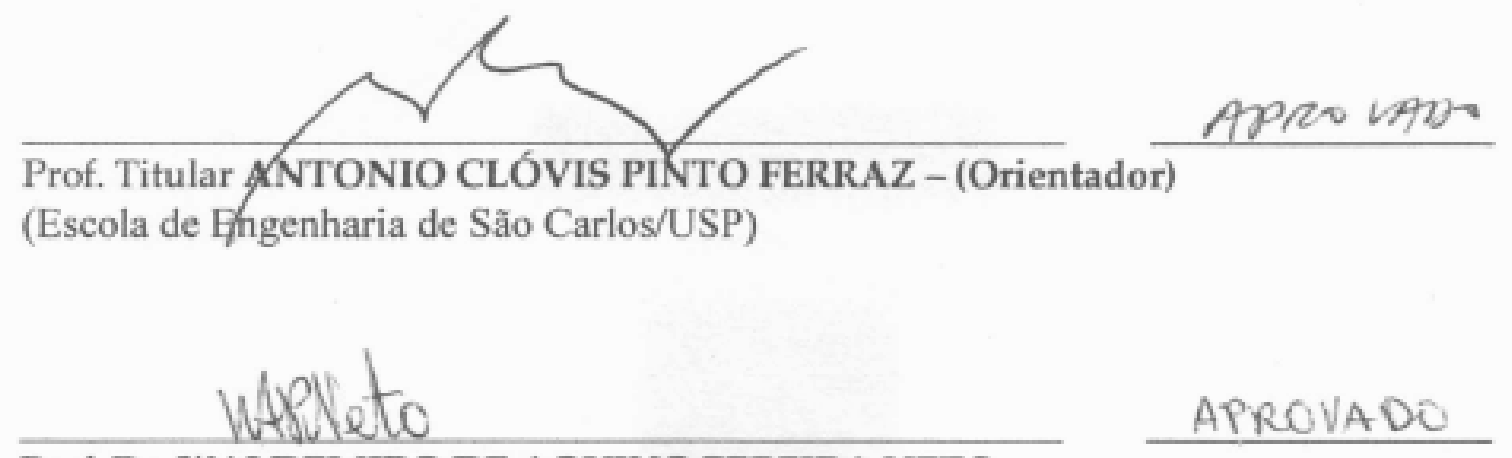

Prof. Dr. WALDEMIRO DE AQUINO PEREIRA NETO

(Universidade Federal de Uberlândia/UFU)

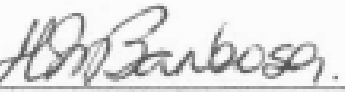

$\triangle P R O V A D O$

Prof ${ }^{2}$. Associada HELOISA MARIA BARBOSA

(Universidade Federal de Minas Gerais/UFMG)

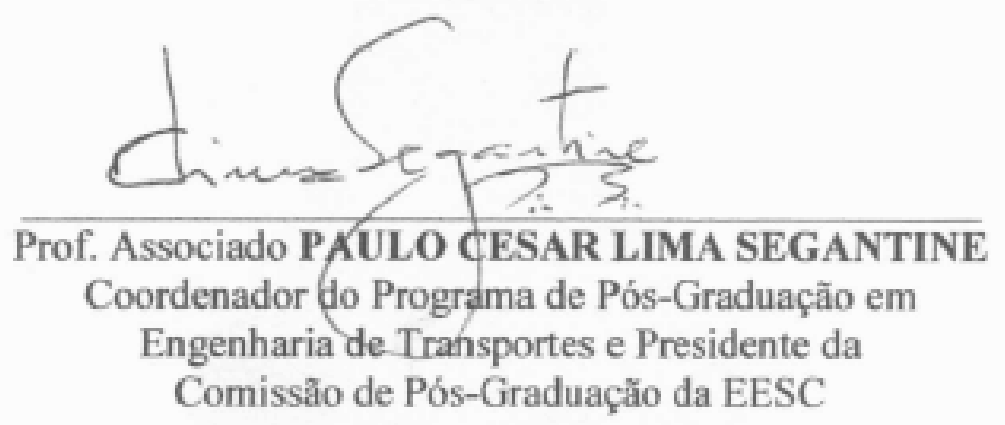





\section{DEDICATÚRIA}

"Dedico essa dissertação aos meus pais Carlos e Luceleide e à minha irmã Carla". 

A Deus.

Ao Prof. Dr. Antonio Clóvis Pinto Ferraz (Coca), pela orientação e amizade.

A Dra. Barbara Stolte Bezerra, pelo imprescindível apoio e amizade fraterna.

A todos os professores da Fatec de Jaú que contribuíram para a minha formação acadêmica; em especial à Professora Cida Cris, pelas sugestões e incentivo, e às Professoras Magaly Romão e Ana Paula Larocca, pela amizade e apoio.

A todos os professores e funcionários do Departamento de Transportes (STT) da EESC-USP, pelo apoio e amizade.

A CAPES, pela bolsa de estudos concedida.

Aos colegas da pós e estimados amigos, Isabela, Tiago e Cândido, obrigada pela paciência, convivência alegre e amizade fraterna.

A todos os amigos do Departamento de Transportes: Mateus, Pablo, Professor Adalberto, Professora Ana Furlan. Em especial, ao Bruno e Cassiano, que mediram esforços para me ajudar.

Aos amigos, Marcini, Madá, Monique, Vivian, Luiz, Robert, lara, Rochele, Ana Paula, Gustavo, Karlinha e Victor, por tudo.

À irmã que fiz em São Carlos, Taís Gastaldi, por ser minha família em São Carlos. 
Aos meus familiares queridos: meu pai, Carlos, minha mãe, Luceleide, minha irmã, Carla, meus avôs (in memorian) e minhas avós. Obrigada pelas orações e incondicional apoio. 
SPIGOLON, L. M. G. Semáforo: grupo focal convencional x grupo focal com informação do tempo de verde/vermelho restante. São Carlos, 2010, 128 p. Dissertação (Mestrado) - Escola de Engenharia de São Carlos, Universidade de São Paulo.

O objetivo desta pesquisa foi comparar o desempenho - em termos de capacidade e segurança - de interseções semaforizadas dotadas de grupos focais convencionais, com as dotadas de grupos focais com informação do tempo de verde/vermelho restante na via principal. Foram analisados três modelos distintos, em relação à maneira que é disposta a informação do tempo de verde/vermelho restante. Os resultados obtidos mostram que praticamente não há alteração no valor da capacidade da passagem de veículos pela interseção semaforizada quando se substitui o grupo focal convencional por grupo focal com informador de tempo. Quanto à segurança, a substituição de grupo focal convencional por grupo focal com informador de tempo na via principal trouxe significativa redução do número de acidentes. No entanto, a questão que se coloca é se o ganho de segurança e estética, dos grupos focais com indicação de tempo, não poderia ser obtido com custos menores com o emprego de focos maiores dotados de LED, com anteparos grandes dotados de orla refletiva e com grupos focais posicionados sobre c (quando for o caso).

Palavras - Chaves: Capacidade. Segurança. Grupo focal. Interseções. Acidentes. 

SPIGOLON, L. M. G. Signal: conventional focus group x focus group with remaining Green/red time information. São Carlos, 2010, 128 p. Dissertação (Mestrado) - Escola de Engenharia de São Carlos, Universidade de São Paulo.

The objective of this research was to compare performance - in terms of capacity and safety of - signalized intersections equipped with conventional focus groups, endowed with the focus groups with remaining green/red time information on the main road. Three different models were analyzes, in the manner in which information on remaining green/red time is displayed. The results show that there is practically no change in the value of the capacity of vehicles crossing the signalized intersection when replacing the conventional focus group for a focus group with time informer. Regarding the safety, the replacement of conventional focus group for focus group with time informer on the main road has brought significant reduction in accidents. However, the question that arises is whether the gain in traffic safety, as well as aesthetics, of the focus groups with indication of time could not be obtained at much lower cost with the use of larger foci (when appropriate), with foci endowed with LED, with large screens equipped with reflective edge and with focus groups positioned on the road (when appropriate).

Key - words: Capacity, Safety, Focus group, Intersections, Accidents. 



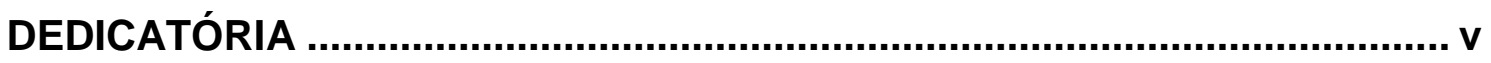

AGRADECIMENTOS .................................................................................. vii

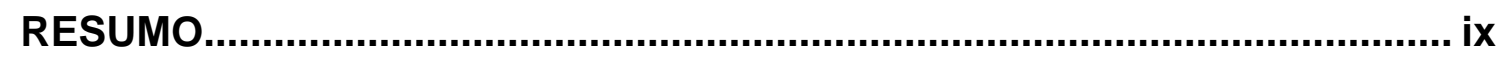

ABSTRACT

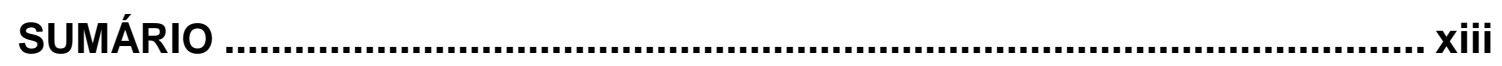

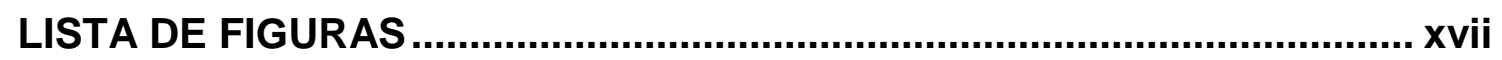

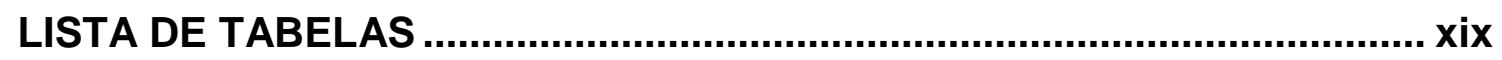

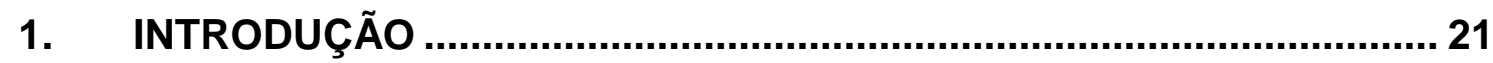

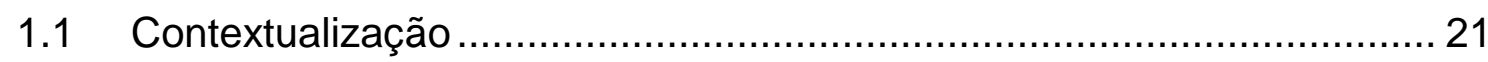

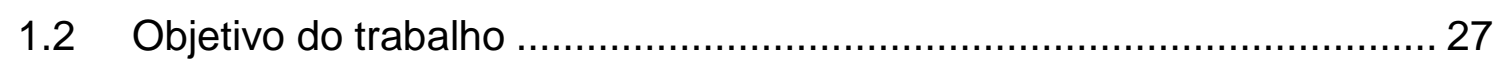

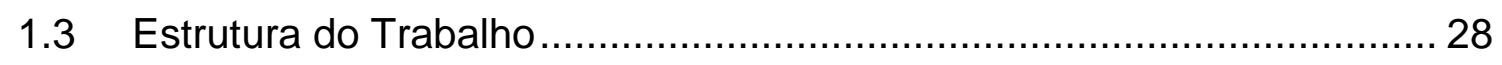

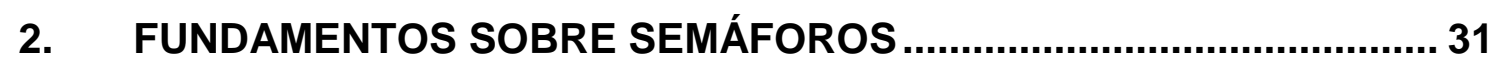

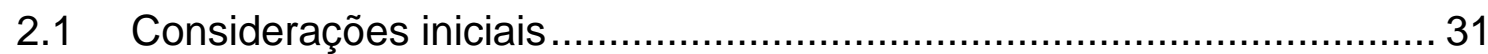

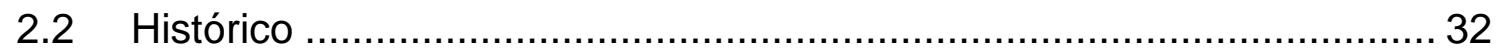

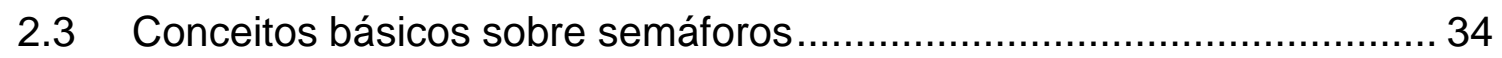

2.3.1 Grupo focal, Estágio, Fase e Diagrama de tempos.............................. 34

2.3.2 Vermelho total e entre verdes ...................................................... 36

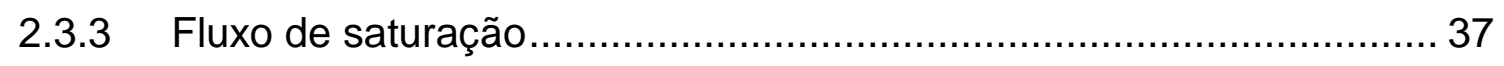

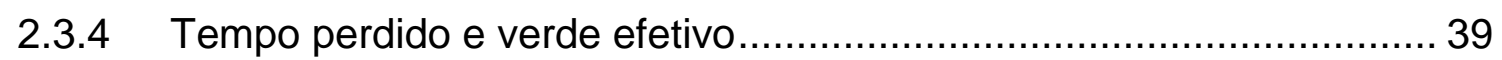

2.3.5 Capacidade e taxa de ocupação ………….................................... 42

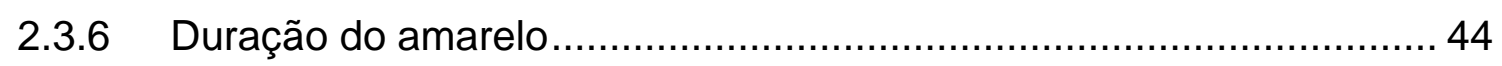

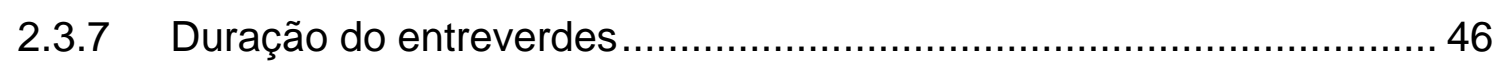

2.4 Duração do ciclo e do verde em semáforos isolados ............................. 47

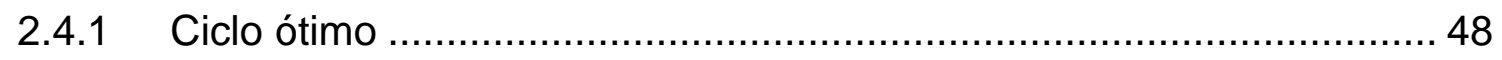

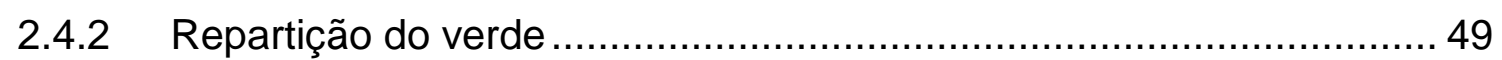

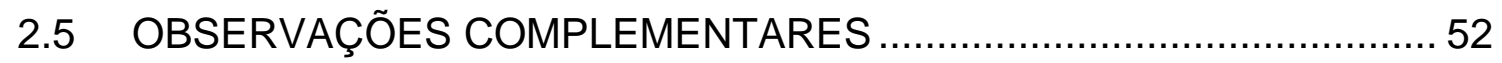

2.5.1 Nível de serviço para cruzamentos semaforizados ............................. 52

2.5.2 Repartição do verde .................................................................. 53 
3. PRINCIPAIS MODELOS DE GRUPOS FOCAIS SEMÁFORICOS VEÍCULARES EMPREGADOS NO PAÍS

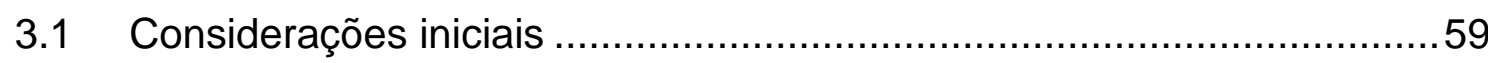

3.2 Modelos de grupos focais empregados no Brasil .................................61

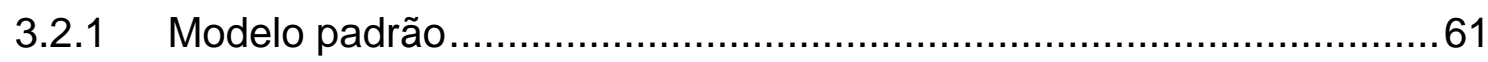

3.2.2 Modelos com informador do tempo de verde/vermelho restante .........62

4. MÉTODO PARA AVALIAÇÃO DA CAPACIDADE EM SEMÁFOROS..67

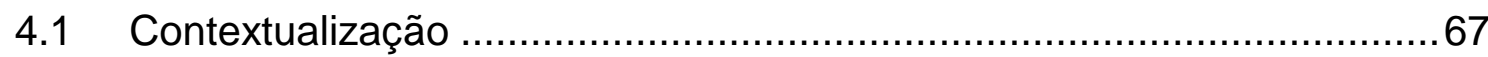

4.2 Método do Australian Road Research Board Ltd..................................67

4.3 Método do DENATRAN ...............................................................

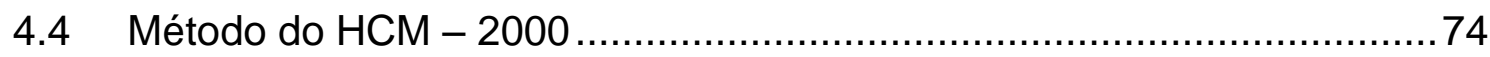

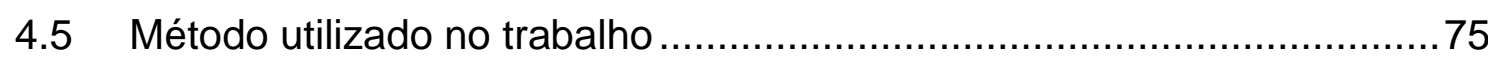

4.5.1 Obtenção do fluxo de saturação e tempo perdido no início do verde ..75

4.5.2 Obtenção do tempo perdido no final da fase .....................................77

4.5.3 Determinação do tempo total perdido e da capacidade........................78

5. AVALIAÇÃO NA SEGURANÇA DE INTERVENÇÕES NO SISTEMA

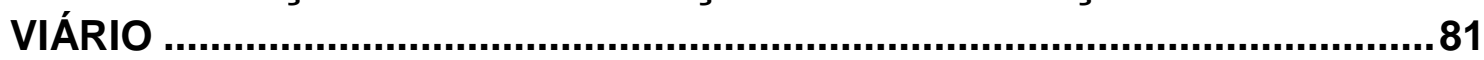

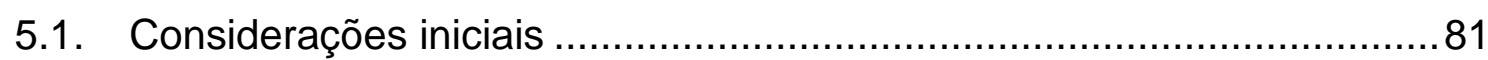

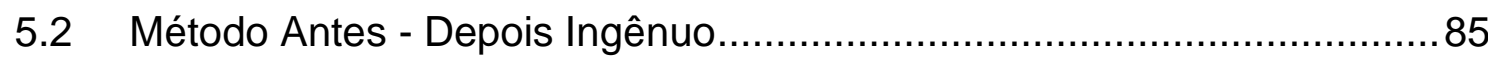

5.3 Método Antes - Depois utilizando grupos de comparação ......................89

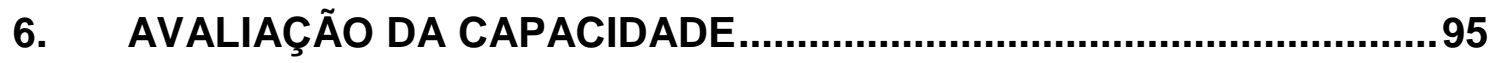

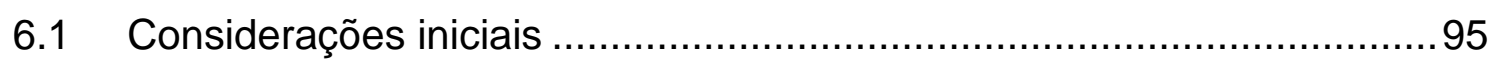

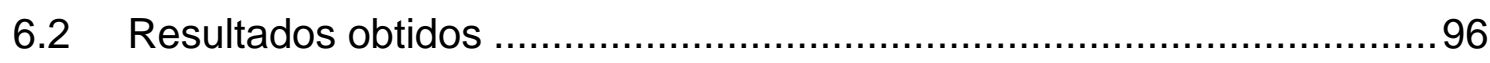

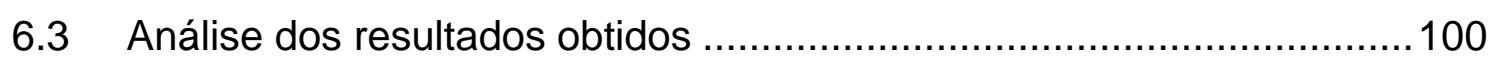

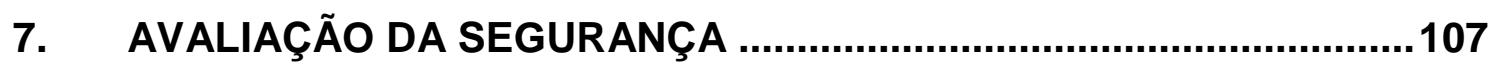

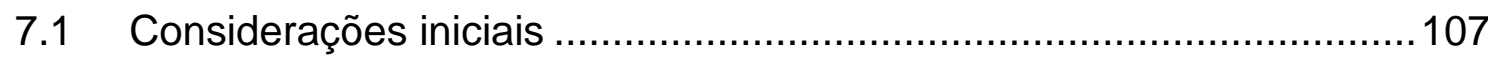

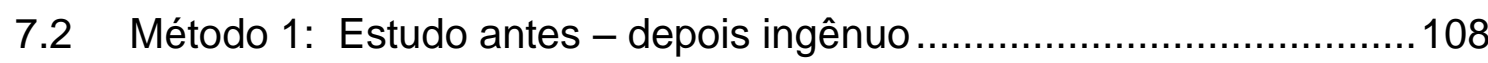

7.3 Método 2: Estudo antes - depois utilizando grupo de comparação........115

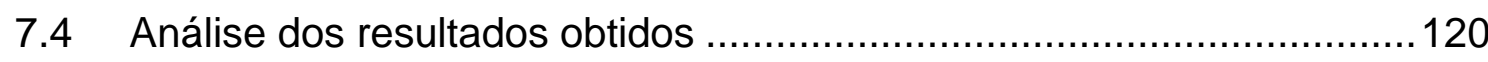

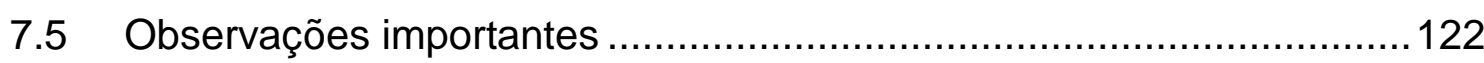




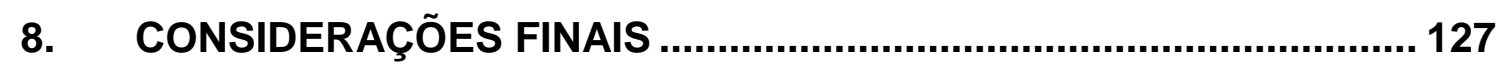

9. REFERÊNCIAS BIBLIOGRÁFICAS ........................................... 131 



\section{LISTA DE FIGURAS}

Figura 2. 1 - Indicações luminosas em semáforos 34

Figura 2. 2 - Operação de semáforo no cruzamento de duas vias de dois sentidos. 36

Figura 2. 3 - Conceito de vermelho total..................................................... 36

Figura 2. 4 - Verde efetivo e tempo perdido ................................................. 40

Figura 2. 5 - Diagrama de fases de um semáforo duas fases...................... 41

Figura 2. 6 - Representação gráfica do fluxo se saturação .......................... 41

Figura 2. 7 - Esquema para determinação da duração do amarelo e do vermelho total. 46

Figura 2. 8 - Atraso médio num semáforo em função da duração do ciclo52 Figura 2. 9 - Variação típica dos principais parâmetros em função do ciclo.54 Figura 2. 10 - Vantagens e desvantagens das colunas e grupos focais antes e depois do cruzamento. 57

Figura 3. 1- Disposição das indicações luminosas .................................... 60

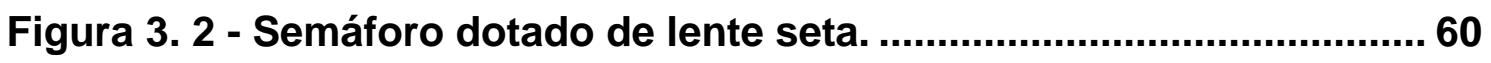

Figura 3. 3 - Grupo focal semafórico sem anteparo na parte de trás......... 61

Figura 3. 4 Semáforo com anteparo na parte de trás ................................. 62

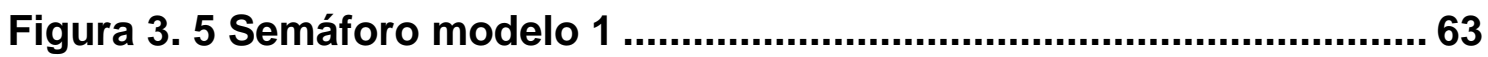




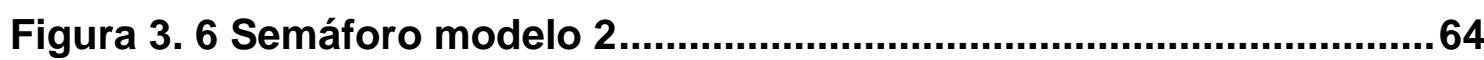

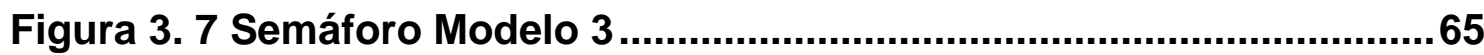

Figura 4. 1- Histograma do método proposto pelo DENATRAN..................72

Figura 5.1 - Comparação da segurança ...................................................... 83

Figura 6. 1 - Variação dos Headway obtidos .............................................101

Figura 6. 2 - Variação do Tempo perdido no início ....................................102

Figura 6. 3 - Variação do tempo perdido no início ....................................103

Figura 6. 4 - Variação do tempo perdido total ...........................................104

Figura 6. 5 - Variação da Capacidade.......................................................105

Figura 6. 6 - Variação da Capacidade supondo não haver variação do headway 106

Figura 7. 1 - Valores estimados da redução dos acidentes 121 


\section{LISTA DE TABELAS}

Tabela 1. 1- Características das cidades analisadas

Tabela 2. 1 - Nível de serviço x atraso médio. 53

Tabela 4. 1 - Fluxo de saturação e tempo perdido ................................. 71

Tabela 4. 2 - Headways numa fila de veículos num semáforo. 76

Tabela 5. 1 - Estimativa quando nem todos os $r_{d}(j)$ são os mesmos. 88

Tabela 5.2 - Estimativa quando todos os $r_{d}(j)$ são os mesmos 88

Tabela 5.8 - Etapas 3 e 4 ........................................................................ 88

Tabela 5. 4 - Contagens de acidentes e valores esperados ..................... 90

Tabela 5. 5 - Estimativas das ETAPAS 1 e 2 em um “Estudo G-C”............. 93

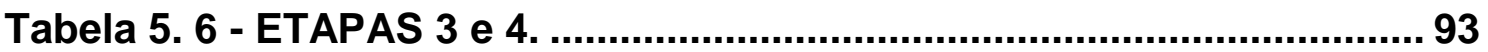

Tabela 5. 7- Cálculo da estimativo do desvio padrão ............................... 93

Tabela 6. 1- Resultados obtidos na cidade de São Carlos........................ 97

Tabela 6. 2 - Resultados obtidos na cidade de Ribeirão Preto................... 98

Tabela 6. 3 - Resultados obtidos na cidade de Piracicaba ........................ 99

Tabela 6. 4 - Resultados obtidos para a capacidade horária ................... 100

Tabela 7. 1- Número de acidentes no ano anterior e posterior à mudança em São Carlos. 109 
Tabela 7. 2- Resultados obtidos em São Carlos

Tabela 7. 3- Número de acidentes no ano anterior e posterior à mudança em Ribeirão Preto 111

Tabela 7. 4- Resultados obtidos em Ribeirão Preto 112

Tabela 7. 5- Número de acidentes no ano anterior e posterior à mudança em Piracicaba 113

Tabela 7. 6- Resultados obtidos em Piracicaba 114

Tabela 7. 7- Número de acidentes em interseções tratadas na cidade de São

Carlos 115

Tabela 7. 8- Número de acidentes em Interseções não tratadas na cidade de São Carlos 116

Tabela 7. 9- Resultados obtidos em São Carlos 116

Tabela 7. 10- Número de acidentes em interseções tratadas na cidade de Ribeirão Preto 117

Tabela 7. 11- Interseções não tratadas na cidade de Ribeirão Preto ........118

Tabela 7. 12- Resultados obtidos em Ribeirão Preto..................................119

Tabela 7. 13- Resultados obtidos nos dois estudos realizados. 120 


\section{INTRロDUÇÃA}

\subsection{Contextualização}

Os congestionamentos e os acidentes de trânsito nas cidades constituem sérios problemas na atualidade.

Os fabricantes de semáforos com grupos focais com indicação do tempo de verde e de vermelho restante - há vários modelos que surgiram no país nos últimos anos afirmam que esses equipamentos aumentam a capacidade e reduzem a acidentalidade nas interseções semaforizadas, além de apresentarem uma estética mais adequada.

No entanto, Elvik \& Vaa (2004) citam que o emprego do verde piscante avisando que a luz verde está prestes a se apagar é previsto conduzir a um aumento entre $30 \%$ e $56 \%$ (média de $42 \%$ ) dos acidentes com vítimas. Nesse sentido, Ferraz et al (2008) colocam o seguinte: "O verde piscante não é utilizado no Brasil. No entanto, algumas cidades têm utilizado grupos focais com indicação digital junto ao grupo focal do tempo restante de verde e de vermelho, ou grupo focal constituído de um conjunto de lâmpadas que vão, uma a uma, sendo apagadas, para dar idéia do tempo restante de verde e de vermelho. Como esses dois sistemas passam aos usuários informações similares ao do verde piscante, é de supor que os impactos na acidentalidade viária sejam similares". 
O Jornal do Fórum (2006) traz a seguinte afirmação de Sayonara Lopes de Souza (membro titular da Câmara Temática de Engenharia de Tráfego, da Sinalização e da Via do CONTRAN): "Os municípios que usam esses equipamentos (grupos focais com informação do tempo restante) em interseções controladas por semáforos estão em desacordo com a Resolução 160/2004 do CONTRAN, que trata da sinalização do trânsito". Segundo Sayonara, o assunto é discutido na Câmara Temática desde 2002, e todos os pareceres realizados indeferiram o equipamento, mesmo assim a sua implantação cresce nas cidades brasileiras.

Seguem alguns casos relatados pelo Jornal do Fórum (2006) sobre o emprego de semáforos com grupos focais com indicação do tempo de verde/vermelho restante.

Em Fortaleza (CE) foi implantado equipamentos similares e foi concluído que não houve redução no número de acidentes, além de gerar dúvidas de interpretação pelos motoristas.

Na cidade de Curitiba (PR) foram instalados 13 semáforos e após 18 meses da implantação, o Setor de Pesquisa, Estatística e Equipamentos de Trânsito, da URBS (Urbanização de Curitiba S.A.) divulgou os seguintes dados: aumento de $64,3 \%$ no número de acidentes, $46,27 \%$ a mais no número de vítimas e crescimento em $150 \%$ de mortos no local.

A Associação Brasileira de Empresas do Setor de Trânsito - ABETRANS (2009) relata os casos que seguem.

A Prefeitura de Vitória (ES) retirou os semáforos com temporizador, pois estudos indicam que os equipamentos contribuem para aumentar o índice de acidentes. 
Por outro lado, as prefeituras de Vila Velha (ES) e de Serra (ES) dizem que os aparelhos contribuem para redução do tempo de espera dos carros em filas e permite a travessia de carros nos cruzamentos com maior segurança.

A ABETRANS (2009) traz ainda o seguinte depoimento da subsecretária de Transporte da Prefeitura de Vitória (ES), Regina Bossanel: "Vendo a indicação de que o sinal está próximo para abrir, muitos carros avançam no último segundo, e aí os acidentes acontecem". A subsecretária diz ainda que, por não ser regulamentado pelo Departamento Nacional de Trânsito (DENATRAN), o uso do semáforo com temporizador implica em responsabilidade da Prefeitura em caso de acidente.

A padronização dos sinais de trânsito é garantida pela legislação de trânsito (Código de Trânsito Brasileiro). A seguir é reproduzido trecho desse código, relevante no que tange à padronização e consequente legalidade da sinalização.

\section{Capítulo VII - DA SINALIZAÇÃO DE TRÂNSITO}

Art. 80. Sempre que necessário, será colocada ao longo da via, sinalização prevista no Código de Transito Brasileiro e em legislação complementar, destinada a condutores e pedestres, vedada a utilização de qualquer outra.

§ 1ํA sinalização será colocada em posição e condições que a tornem perfeitamente visível e legível durante o dia e a noite, em distância compatível com a segurança do trânsito, conforme normas e especificações do CONTRAN.

$\S 2^{\circ}$ O CONTRAN poderá autorizar, em caráter experimental e por período prefixado, a utilização de sinalização não prevista no Código de Transito Brasileiro. O CONTRAN editará normas complementares no que se refere à interpretação, colocação e uso da sinalização.

Capítulo VIII - DA ENGENHARIA DE TRÁFEGO, DA OPERAÇÃO, DA FISCALIZAÇÃO E DO POLICIAMENTO OSTENSIVO DE TRÂNSITO. 
Art. 91. O CONTRAN estabelecerá as normas e regulamentos a serem adotados em todo o território nacional, quando a implantação das soluções adotadas pela Engenharia de Tráfego, assim como padrões a serem praticados por todos os órgãos do Sistema Nacional de Trânsito.

Conforme a ABETRANS (2009), “o Departamento Nacional de trânsito (DENATRAN) dispõe de uma norma geral para a sinalização semafórica, definida na Resolução 160. Mas ela só prevê o equipamento convencional, que faz uso de lâmpadas incandescentes. Com o avanço tecnológico e o surgimento de outros equipamentos no mercado, como lâmpadas leds e temporizadores, a Câmara Temática de Engenharia de Tráfego, da Sinalização e da Via do DENATRAN está elaborando novos manuais sobre o assunto, atualizando a norma vigente."

Segundo estudos realizados por Beck, Jacques e Andrade (1996), a utilização do semáforo com informador auxiliar de tempo produz impactos positivos no desempenho operacional da interseção no que se refere à capacidade, aumentando o fluxo de saturação e reduzindo o tempo perdido.

Segundo Gonçalves (1980), a clareza, a rapidez e a constância na transmissão da mensagem pela sinalização dependem de sua uniformidade. Entende-se por sinalização uniforme aquela que:

- Utiliza sempre os mesmos sinais para transmitir a mesma mensagem

- Obedece sempre a mesma lógica, em termos de conotação negativa ou positiva

- É empregada sempre com a mesma intenção, com sinais adequados a cada situação 
- É usada sempre da mesma maneira, quando se quer transmitir a mesma mensagem em locais com características geométricas, de uso e de visibilidade semelhantes

- É instalada sempre no mesmo lugar, quando se considera o campo de visão do motorista e

- Utiliza sempre o mesmo tipo de suporte físico e visual.

A rapidez na transmissão da mensagem talvez seja a característica que sofra o maior impacto da uniformidade. Ela depende do tempo gasto na procura do sinal, na observação, na decodificação e na compreensão.

Quando a sinalização não é uniforme, o tempo de busca pode ser tão grande que a percepção e a transmissão da mensagem se tornem não executáveis.

A clareza na transmissão da mensagem depende dos próprios símbolos adotados. Mas, considerando-se um dado conjunto de sinais, a uniformidade influi na clareza por meio da ação de dois fatores: a expectativa do motorista e o contraste do sinal com o fundo background.

Quando é utilizada sinalização uniforme, os condutores sabem que sinais podem esperar ser encontrados em cada situação e em cada local. Isso cria uma expectativa em torno da placa ou marcas que se aproximam à medida que o veículo se movimenta. Com isso, em cada situação, o número de sinais possíveis diminui, seja pelo hábito do motorista, seja porque ele aprende a lógica que rege o uso da sinalização. 
Até mesmo a constância na transmissão da sinalização melhora com o uso de sinalização uniforme de trânsito, uma vez que são praticamente eliminados sinais inesperados que necessitariam altos valores de relevância e visibilidade para serem percebidos pelo motorista.

Assim Gonçalves (1980) conclui que é mais fácil ver as coisas quando se sabe onde procurar por elas e, por outro lado, é mais fácil ler algo quando existe noção prévia do que pode estar escrito.

Nos Estados Unidos a norma principal que rege a aplicação, projeto e colocação de dispositivos de controle de tráfego é a atual edição do Manual On Uniform Traffic Control Devices (MUTCD). O Federal Highway Administration publicou o MUTCD nacional que serve como norma mínima e um modelo de MUTCDs para um estado em particular. (ROESS, PRASSAS, MCSHANE 2004).

O Federal Highway Administration (2003) não traz informações sobre outros tipos de semáforo a não ser os convencionais citados pelo Código de Trânsito Brasileiro.

Não se sabe de nenhuma nação desenvolvida que utilize modelos de grupos focais veiculares com indicação do tempo de verde e vermelho restante, ou seja, em desacordo com o padrão internacional.

À luz do exposto, infere-se que:

- Há dúvidas sobre a legalidade do emprego de grupos focais com indicação do tempo de verde/vermelho restante 
- A padronização da sinalização de trânsito - com os benefícios associados não são verificados em alguns modelos de grupos focais com indicação do tempo de verde e de vermelho restante

- Há sérias dúvidas sobre as vantagens em termos de capacidade e segurança dos semáforos dotados de indicação do verde/vermelho restante.

Este trabalho de pesquisa visa contribuir para a avaliação do desempenho operacional de semáforos dotados de grupos focais com indicação do tempo de verde/vermelho restante, mediante a comparação da capacidade e da segurança de interseções semaforizadas dotadas de grupos focais comuns com outras dotadas de grupos focais com indicação do tempo de verde/ vermelho restante.

\subsection{Objetivo do trabalho}

O objetivo deste trabalho de pesquisa é comparar o desempenho, em termos de capacidade e segurança, de interseções semaforizadas dotadas de grupos focais comuns com outras dotadas de grupos focais com indicação do tempo de verde/ vermelho restante.

São analisados três diferentes modelos de indicação do tempo de verde/vermelho restante: por intermédio de focos com tamanho normal com luzes que vão se apagando (o estudo foi realizado comparando o desempenho de semáforos localizados na cidade de São Carlos); com focos de tamanho pequeno com luzes que vão se apagando situadas ao lado dos focos de tamanho normal que se mantém acesos conforme o padrão convencional (o estudo foi realizado comparando o desempenho de semáforos localizados na cidade de Ribeirão Preto); e com visor contendo informação digital ao lado dos focos de tamanho normal que 
se mantém acesos conforme o padrão convencional (o estudo foi realizado comparando o desempenho de semáforos localizados na cidade de Piracicaba).

As características das cidades onde se realizaram os estudos encontram-se Tabela 1.1.

Tabela 1. 1- Características das cidades analisadas

\begin{tabular}{ccc}
\hline & $\begin{array}{c}\text { População } \\
\text { (Estimativa 2009) }\end{array}$ & $\begin{array}{c}\text { Frota de veículos } \\
\text { (Fevereiro 2010) }\end{array}$ \\
\hline São Carlos & 220.463 & 120.384 \\
\hline Ribeirão Preto & 563.107 & 368.030 \\
\hline Piracicaba & 368.843 & 210.537 \\
\hline
\end{tabular}

* Fonte: IBGE (http://www.ibge.gov.br/cidadesat/topwindow.htm?1)

${ }^{* *}$ Fonte: DENATRAN (http://www.denatran.gov.br/frota.htm)

\subsection{Estrutura do Trabalho}

Este trabalho encontra-se dividido em nove capítulos.

O Capítulo introdutório congrega a contextualização do problema, o objetivo e a estrutura do trabalho.

O Capítulo 2 apresenta os fundamentos sobre semáforos: história, conceitos básicos duração do ciclo e do verde em semáforos isolados e observações complementares, assim como arranjo físico dos semáforos.

No Capítulo 3 são apresentados os principais modelos de grupos focais semafóricos empregados no país. 
No Capítulo 4 são descritos alguns métodos existentes para a avaliação da capacidade os quais serviram de instrumento para a elaboração de um método mais adequado para o presente trabalho.

No Capítulo 5 são descritos os métodos de análise da segurança que foram empregados nesta pesquisa.

No Capítulo 6 é apresentada análise comparativa da capacidade do fluxo de veículos nos diferentes tipos de grupos focais semafóricos.

No Capítulo 7 é apresentada análise comparativa da acidentalidade no trânsito nos diferentes tipos de grupos focais semafóricos.

No Capítulo 8 são feitas algumas considerações relevantes no contexto do trabalho.

Por fim são apresentadas as referências. 


\section{FUNDAMENTIS SRBRE SEMÁFロRロS}

\subsection{Considerações iniciais}

As vias são o meio físico de circulação de veículos e pedestres. No cruzamento de duas ou mais vias, existem movimentos de veículos que não podem ser realizados simultaneamente, pois são conflitantes entre si. Nesses locais, é necessário estabelecer alguma norma de controle do direito de passagem, melhorar as condições de fluidez e reduzir os riscos de acidentes, tanto entre veículos como entre veículos e pedestres.

Uma forma simples de controle bastante empregada é definir como preferencial, que terá prioridade de entrada no cruzamento a via com maior volume de tráfego denominado principal; nesse caso os veículos da via secundária, a que possui menor volume de tráfego devem parar, ou reduzir a velocidade, dando preferência aos veículos da via principal. Nesse tipo de operação é geralmente usado placas de PARE, ou, mais raramente no Brasil, DÊ A PREFERÊNCIA, nas aproximações das vias secundárias.

No entanto, dependendo do volume de tráfego da via principal, os veículos na via secundária podem ser prejudicados, sofrendo grandes demoras para atravessar o cruzamento. Uma alternativa a tais acontecimentos é a implantação de semáforo, 
dispositivo que alterna o direito de passagem mediante indicação luminosa com cores distintas.

De acordo com o DNER (1971) é denominado semáforo "Todos os dispositivos reguladores do trânsito urbano, acionados por meio de corrente elétrica, excetuando as luzes intermitentes, sinais e marcações por meio das quais o trânsito é alertado ou orientado a seguir as instruções que estas indicam".

Uma definição mais generalista é que semáforo constitui dispositivo de controle de tráfego que, através de indicações luminosas transmitidas para motoristas e pedestres, alterna o direito de passagem de veículos e/ou pedestres em interseções de duas ou mais vias. Compõe-se de focos luminosos afixados em grupos ao longo da via ou suspensos sobre ela, através de elementos de sustentação (postes). (Manual de Semáforo 1984)

Para Cucci Neto (1999) "semáforo é um subsistema da sinalização viária que se compõe de luzes acionadas alternadas ou intermitentemente através de sistema elétrico/eletrônico, cuja função é controlar os deslocamentos".

\subsection{Histórico}

O início do século XX foi marcado pelo advento do uso massificado do automóvel, o que levou à necessidade de organizar o tráfego nos grandes centros urbanos. Uma maneira de garantir o direito de passagem e organizar o tráfego nas interseções foi o semáforo. O primeiro semáforo manual surgiu no ano de 1868, em Londres, Inglaterra. 
Apenas em 1913 o semáforo elétrico, como o atualmente utilizado, foi desenvolvido. A autoria dessa idéia foi do norte americano James Hoge. Cleveland (EUA) foi a primeira cidade a instalar essa invenção. Tal dispositivo foi precursor do semáforo de três cores, popularizado na década de 1920 nos Estados Unidos, devido ao grande crescimento da frota de automóveis.

A partir do invento de Hoge, os sinais luminosos passaram a ser cada vez mais usados. Salt Lake City teve a primeira instalação de semáforos interconectados em 1917. Porém o advento do semáforo levou a necessidade de uma progamação eficiente. O sistema de programação semafórica foi proposto em 1922 e os primeiros semáforos atuados pelo tráfego foram instalados em New Haven, East Norwalk e Baltimore, EUA, em 1928.

Atualmente, a micro-informática também faz avanços no campo do controle de tráfego, os semáforos são equipados com micro-computadores e se comunicam com um computador central via modems ou linha dedicada. (SETTI, 2002).

Nos últimos anos, muitos progressos ocorreram acerca da sinalização semafórica, tanto na parte dos componentes físicos, como na parte metodológica e teórica.

"O marco inicial das teorias sobre o desempenho dos semáforos são os trabalhos do Transportation Research Board - TRB (1950), denominado Highway Capacity Manual-HCM (1950) e de Webster (1958). As teorias deste último são bastante utilizadas até hoje devido à precisão dos resultados apresentados - no mesmo nível dos obtidos nos sofisticados simuladores atualmente disponíveis". (BEZERRA, 2007 apud TÁPIA, 2003). 
Quanto ao semáforo com informador de tempo restante são se tem notícias do local e data do seu surgimento.

\subsection{Conceitos básicos sobre semáforos}

Algumas definições e medidas de desempenho estão diretamente relacionadas com

a operação de semáforos. Neste item será descrito conceitos sobre grupo focal, estagio, fase e diagrama de tempos.

\subsubsection{Grupo focal, Estágio, Fase e Diagrama de tempos}

Grupo focal é a denominação dada ao conjunto de focos (lentes coloridas nas cores vermelha, amarela e verde) que controlam cada conjunto de movimentos no cruzamento semaforizado.

A Figura 2.1 traz ilustração das indicações luminosas padrões dos focos semafóricos.
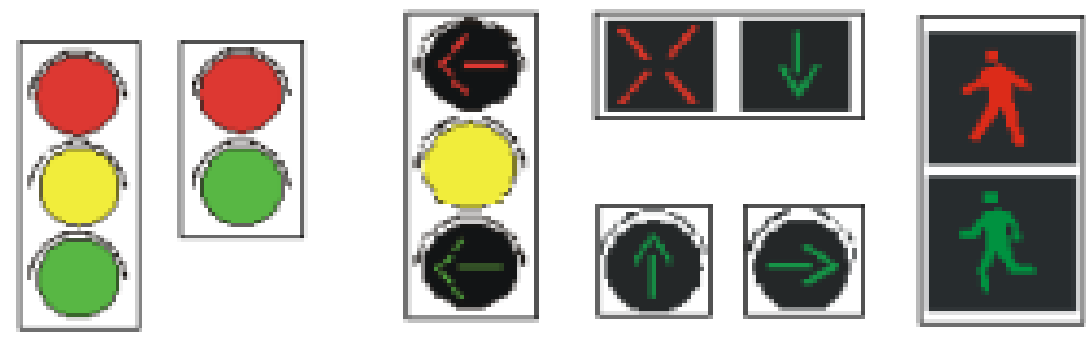

Figura 2. 1 - Indicações luminosas em semáforos

(Fonte: Ferraz, 2005)

Na literatura a letra $V$ é empregada para indicar o grupo focal para veículos e a letra $\mathrm{P}$ para pedestres. A letra $\mathrm{R}$ indica a cor vermelha, $\mathrm{G}$ indica a cor verde e $\mathrm{Y}$ indica a cor amarelo. 
Estágio refere a cada diferente movimento no cruzamento semaforizado. Assim, durante um estágio a indicação luminosa de todos os grupos focais não se altera.

Fase refere as diferentes configurações de movimento onde pelo menos um dos fluxos continua em movimento, ainda que um ou mais fluxos sejam interrompidos para permitir o movimento de outro (s) fluxos que estavam interrompidos. As várias configurações distintas dentro de uma fase são denominadas de subfases. Diante disso, as subfases coincidem com os estágios.

O diagrama de tempos (Figura 2.2) mostra o comportamento das indicações de luzes nos vários grupos focais nas diversas fases ao longo do tempo.

As indicações luminosas (verde, amarelo, vermelho) dos vários grupos focais dos semáforos se repetem, normalmente, de maneira idêntica ao longo do tempo, caracterizando um fenômeno periódico ou cíclico. Dessa forma, denomina-se ciclo de um semáforo o período de tempo em que a sucessão de indicações luminosas se repete de forma análoga.

Na Figura 2.2 é exposto o plano de operação semafórico (diagrama de estágios, fases e tempos) frequentemente usado no caso simples de um cruzamento de duas vias de sentido único. 


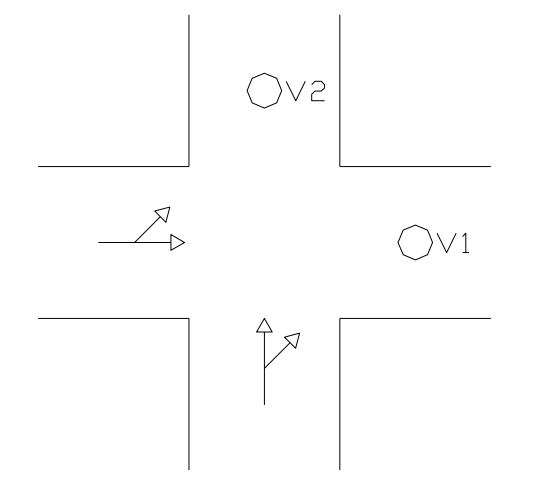

Diagrama de Estágios

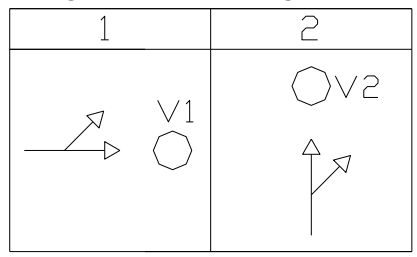

Diagrama de Tempos

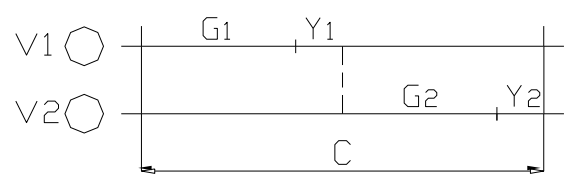

Diagrama de Fases

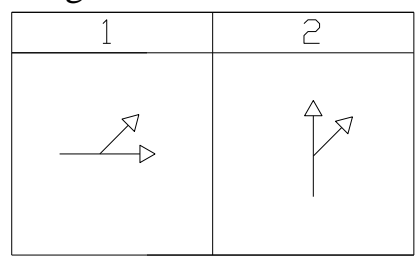

Figura 2. 2 - Operação de semáforo no cruzamento de duas vias de dois sentidos (Fonte: Ferraz, 2005)

\subsubsection{Vermelho total e entre verdes}

Vermelho total é o tempo em que há indicação luminosa vermelha em todos os grupos focais. Desta forma, fica proibida a passagem de fluxos conflitantes, aumentando a segurança na operação do cruzamento. O vermelho total ocorre logo após a indicação luminosa do amarelo. A Figura 2.3 ilustra esse fato.

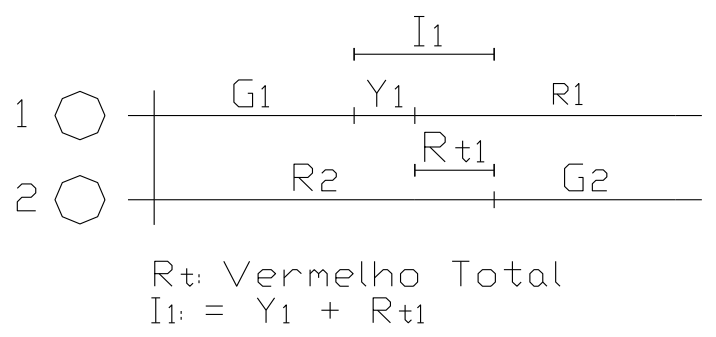

(Fonte: Ferraz, 2005)

Figura 2. 3 - Conceito de vermelho total

Denomina-se período de entreverdes (I) a soma do amarelo $(\mathrm{Y})$ com o vermelho total (Rt), assim temos a seguinte equação: 
$I=Y+R t$

\subsubsection{Fluxo de saturação}

O fluxo de saturação corresponde ao máximo fluxo de veículos numa faixa de tráfego que pode passar por um cruzamento semaforizado quando a luz está verde.

No caso do movimento na faixa não sofrer interrupções momentâneas devido a fatores externos, o fluxo de saturação depende dos seguintes fatores:

- largura da faixa de tráfego

- inclinação longitudinal da via

- porcentagem de veículos pesados (ônibus e caminhões) e

- porcentagem de veículos que fazem conversão à direita e/ou à esquerda

- tipo e estado de conservação do pavimento

Os seguintes fatos podem, contudo, bloquear momentaneamente o movimento na faixa analisada, reduzindo o fluxo de saturação na mesma:

- manobras de veículos para estacionar ou sair de estacionamento junto ao meio-fio

- entrada e saída de ônibus de pontos de parada

- presença de pedestres e/ou bicicletas cruzando a via quando o fluxo fica verde retardando a passagem de veículos (o que ocorre nas áreas comerciais de grande movimento)

- entrada e saída de veículos da faixa para acessar estacionamentos fora da via pública

- postos de combustível, e 
- $\quad$ paradas de veículos na faixa para embarque e desembarque de passageiros.

O impacto negativo das manobras de estacionamento ou entrada e saída da faixa depende da distância do cruzamento onde a manobra é realizada (se a mais de 75 metros a influência é desprezível) e da freqüência dessas manobras.

Em vista disso, recomenda-se, sempre que possível, medir o fluxo de saturação nas diversas faixas de tráfego no campo. A medida do fluxo de saturação no campo é relativamente simples: basta contar a quantidade de veículos que passam pela linha de retenção quando a fila de veículos em movimento na luz verde é contínua e dividir o valor obtido pelo tempo da contagem. Para obter valores representativos é importante efetuar a contagem para diversos períodos de verde e calcular a média dos valores obtidos - que é o mesmo que dividir a soma do número de veículos obtido em cada contagem pela soma dos tempos correspondentes a cada contagem.

Pesquisas de campo mostram que o fluxo de saturação no caso ideal (faixa de tráfego larga, terreno plano, trânsito constituído apenas com carros passando direto, sem manobras para estacionamento na faixa e sem entradas e saídas de veículos na faixa) situa-se em torno de 1900 veículos/hora, o que corresponde a um intervalo de tempo entre a passagem de veículos consecutivos (headway) de 1,89s.

O fluxo de saturação pode ser obtido pela seguinte expressão:

$s=\frac{3.600}{h}$

Sendo:

s: Fluxo de saturação (veículo/hora/faixa) 
h: Headway de saturação

O headway (h) é definido como o intervalo de tempo que decorre entre a passagem dos pára-choques dianteiros de veículos sucessivos em um mesmo ponto da via.

\subsubsection{Tempo perdido e verde efetivo}

Quando a luz muda para verde, a fila de veículos não parte no mesmo instante. Isso acontece devido ao tempo de percepção e reação (latência) dos motoristas e o tempo de aceleração dos veículos. Esse tempo é chamado tempo perdido (l1) e pode variar conforme o tipo de motorista, tipo de veículo, inclinação da via etc.

A luz amarela dos semáforos indica que o tempo de verde acabou e que irá começar o tempo de vermelho. Esse tempo de amarelo permite ao motorista que esteja muito próximo do cruzamento possa passar com segurança ou parar com conforto.

Contudo, por motivos de segurança, deve existir um intervalo de tempo (l2) entre o último veículo de uma fase e o início da movimentação do primeiro veículo da fase seguinte. Por isso, uma parcela do final do tempo de amarelo (ou do entreverdes se existir vermelho total) não será utilizada.

Portanto, o tempo total perdido em cada fase será:

$L i=l 1+l 2$

Em virtude do tempo perdido no início do verde e no fim do entreverdes (amarelo mais vermelho total), o tempo realmente disponível para a travessia de veículos na fase i, e que é denominado verde efetivo, é dado pela expressão:

$G e_{i}=G i+I_{i}-L_{i}$ 
Sendo:

Gei: Tempo de verde efetivo

Gi : Tempo de verde real

$I_{i}:$ Entreverdes

$L_{i}:$ Tempo total perdido

A Figura 2.4 ilustra o conceito de tempo perdido e verde efetivo.

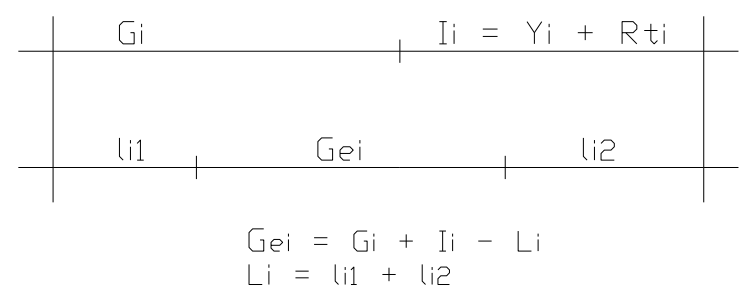

Figura 2. 4 - Verde efetivo e tempo perdido

(Fonte: Ferraz, 2005)

Como os valores de $I_{i}$ e $L_{i}$ resultam em geral, próximos, é comum na prática adotar $G e_{i}=G i$

Portanto, o verde efetivo total do ciclo é igual a:

$G e=\sum G e i=\sum(G i+I i-L i)=\sum(G i+I i)-\sum L i=C-L$

Assim, o verde efetivo total no ciclo é igual ao tempo de ciclo menos a soma dos tempos perdidos nas mudanças de fase (tempo total perdido no ciclo).

Para o caso simples de um semáforo de duas fases, conforme ilustrado na Figura 2.5, o verde efetivo total do ciclo é igual a: 
$G e=G e_{1}+G e_{2}=\left(G_{1}+I_{1}-L_{1}\right)+\left(G_{2}+I_{2}-L_{2}\right)=\left(G_{1}+I_{1}+G_{2}+I_{2}\right)-\left(L_{1}+L_{2}\right)=C-L$
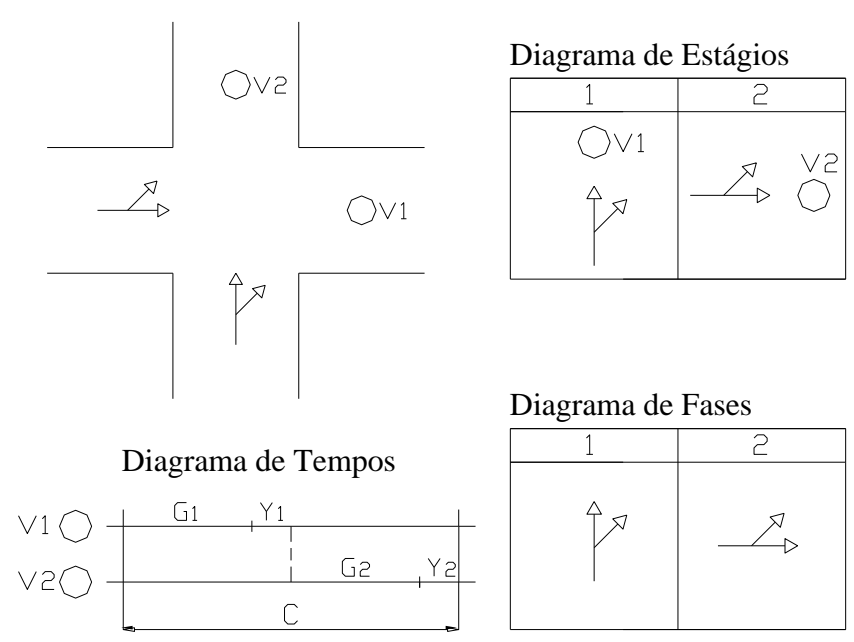

Figura 2. 5 - Diagrama de fases de um semáforo duas fases.

(Fonte: Ferraz, 2005)

A Figura 2.6 ilustra o conceito de tempo perdido e de fluxo de saturação.

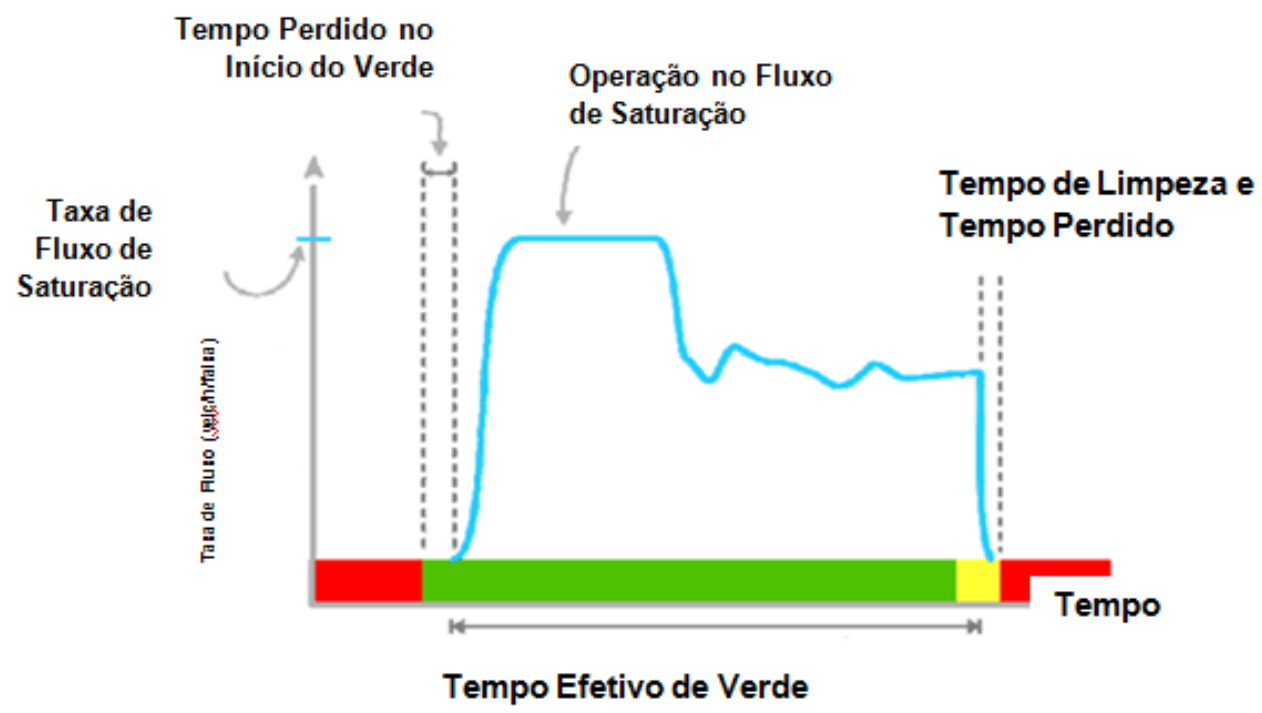

Figura 2. 6 - Representação gráfica do fluxo se saturação

(Fonte: Fornaciari, 2010) 


\subsubsection{Capacidade e taxa de ocupação}

A capacidade de tráfego de cada faixa j que se movimenta na fase i é calculada pela expressão:

$C_{j}=s_{j} * \frac{G e_{j}}{C}=s_{j} * \lambda$

Sendo:

$C_{j}$ : Capacidade de tráfego

$s_{j}$ : Fluxo de saturação

$G e_{j}$ : Duração do verde efetivo

C: Duração do ciclo

$\lambda: \mathrm{Ge} / \mathrm{C}:$ Fração do verde efetivo no ciclo

A taxa de ocupação da faixa j é dada pela expressão:

$y_{j}=q_{j} / s_{j}$

Sendo:

$y_{j}$ : Taxa de ocupação,

$q_{j}$ : Fluxo de tráfego e

$s_{j}$ : já definido. 
O grau de saturação ou índice de congestionamento da faixa j é /dado pela expressão:

$x_{j}=\frac{q_{j}}{c_{j}}=q_{j} * \frac{C}{s_{j}} * G e_{i}=\left(\frac{q_{j}}{s_{j}}\right) *\left(\frac{C}{G e_{i}}\right)=\frac{q_{j}}{\lambda} * s_{j}$

Sendo:

$x_{j}:$ Grau de saturação

$q_{j}, c_{j}, \mathrm{C}, G e_{i}, \lambda$ : já definidos.

Se $x_{j}>1$, a faixa está congestionada e as esperas dos veículos são elevadas. $\mathrm{Na}$ realidade, a partir de $\mathrm{x}=0,9$ as esperas já começam a ser elevadas e a qualidade da operação (nível de serviço) já se torna insatisfatória.

O maior grau de saturação da fase i é denominado grau de saturação crítico da fase i, e a faixa onde isso ocorre de faixa crítica da fase i, é dado pela expressão abaixo:

$x_{c}^{i}=\operatorname{maior} x_{j}^{i}$

Como $\mathrm{C} /$ Gei tem o mesmo valor para todas as faixas que se movem na fase i do semáforo, na faixa crítica também ocorre a maior taxa de ocupação (taxa de ocupação crítica), ou seja:

$y_{c}^{i}=\operatorname{maiory}_{j}^{i}=\left(\frac{q_{j}}{s_{j}}\right) c^{i}=\left(\frac{q}{s}\right)_{c}^{i}$

O grau de saturação (índice de congestionamento) global da interseção é dado pela expressão:

$X=\left(\sum q_{c}^{i} * x_{c}^{i}\right) /\left(\sum q_{c}^{i}\right)$ 
Sendo:

$X$ : Índice de congestionamento global do cruzamento

$q_{c}^{i}:$ Fluxo na faixa crítica da fase i e

$x_{c}^{i}$ : Grau de saturação na faixa crítica da fase i.

O valor de X é indicativo de quanto a capacidade da interseção está sendo utilizada.

A capacidade total do cruzamento semaforizado é igual à soma das capacidades individuais das faixas críticas, sendo dado pela expressão:

$\operatorname{Cap}=\sum c_{j}=\sum s_{j} * G e_{j} / C$

Se o valor de s for o mesmo para todas as faixas críticas, resulta da expressão:

Cap $=\sum s_{j} * \frac{G e_{i}}{C}=\frac{s}{\Sigma^{i}}=s * \frac{G e}{C}=s * \frac{(C-L)}{C}$

Quanto maior o valor do ciclo, maior a capacidade total do cruzamento.

\subsubsection{Duração do amarelo}

A duração do tempo de amarelo tem que ser sucifiente para que os veículos que estão muito próximo do cruzamento, e, portanto, sem condições de parar com segurança e conforto antes da linha de retenção, possam prosseguir e passar por essa linha no amarelo, não passando na interseção no vermelho.

A distância de frenagem é definida, para efeito de análise da operação de paradas de veículos em semáforos, como a distância percorrida por um veículo desde que 
apareceu a luz amarela até a parada final. De acordo com as leis da Física, esta distância é dada pela seguinte expressão:

$D f=V * T p r+\frac{V^{2}}{2 * a}$

Sendo:

$D f$ : Distância de frenagem em metros

$V$ : Velocidade de aproximação em metros por segundo

Tpr: Tempo de percepção e reação em segundos (normalmente adotado igual a 1 segundo)

a: Desaceleração em $\mathrm{m} / \mathrm{s}^{2}$ (normalmente adotada igual a $3 \mathrm{~m} / \mathrm{s}^{2}$ )

Considerando um veículo se aproximando a uma distância $D f$ quando aparece a luz amarela (situação crítica, pois se trata do último veículo a passar), a duração do amarelo deve ser igual ao tempo que o veículo demora para percorrer a distância $D f$, ou seja:

$Y=\frac{D f}{V}$ ou $Y=T p r+\frac{V}{2 a}$

Sendo:

$Y$ : Duração do tempo de amarelo em segundos

$D f, V, T p r$ e $a$ já definidos. 


\subsubsection{Duração do entreverdes}

Após passar na faixa de retenção no final do amarelo, o último veículo deve sair da área da interseção antes do sinal ficar verde para os fluxos conflitantes de veículos e pedestres. Isso significa que, nos casos mais comuns, a distância $S+F+V+F+C$, conforme indicado na Figura 2.7, deve ser percorrida durante o vermelho total.

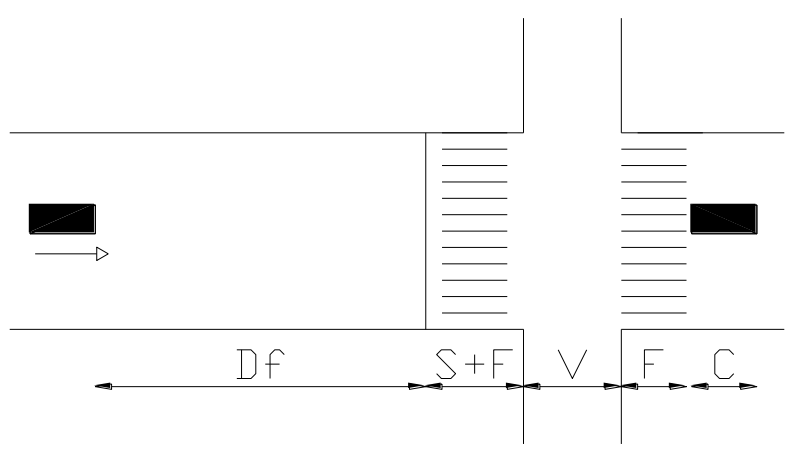

Figura 2. 7 - Esquema para determinação da duração do amarelo e do vermelho total (Fonte: Ferraz, 2005)

Admitindo que o veículo percorra essa distância com velocidade constante, a duração do vermelho total deve ser igual a:

$R t=\frac{S+2 F+V+C}{V}$

Sendo,

Rt: vermelho total em $\mathrm{s}$,

$S$ : distância da linha de retenção até a faixa de pedestres em $\mathrm{m}$ (normalmente igual a $1 \mathrm{~m})$ 
$F$ : largura da faixa de pedestres em $\mathrm{m}$ (normalmente igual a $4 \mathrm{~m}$ )

$V$ : largura da via a ser cruzada em $\mathrm{m}$

$C$ : comprimento do veículo em $\mathrm{m}$ (normalmente adotado igual a $6 \mathrm{~m}$ ).

Essa expressão não leva em conta, contudo, que tanto veículos como pedestres não iniciam a travessia imediatamente após a luz ficar verde. Na realidade, eles somente começam a se movimentar após o tempo de percepção e reação. Assim, ainda dentro de um padrão adequado de segurança, pode-se calcular a duração do vermelho total através da expressão:

$R t=\frac{S+2 F+V+C}{V}-T p r$

Dessa forma, a duração do entreverdes deve ser igual a:

$I=Y+R t=\frac{V}{2 * a}+\frac{S+2 F+V+C}{V}$

Os valores obtidos para a duração do amarelo e do vermelho total devem ser aproximados para o número inteiro mais próximo.

Muitas cidades não utilizam o vermelho total, utilizando o amarelo durante todo o período de entreverdes - o que aumenta um pouco o risco de acidentes nos cruzamentos.

\subsection{Duração do ciclo e do verde em semáforos isolados}

De acordo com Ferraz (2005), um semáforo é isolado quando o processo de chegada dos veículos é ao acaso (aleatório), isto é, não sofre influência de outros semáforos situados a montante, ou outros fatores que possam interferir na 
aleatoriedade do fenômeno. Do ponto de vista prático, pode-se considerar um semáforo como isolado quando não existe outro a montante numa distância de 500 metros.

A duração de um ciclo semafórico corresponde ao intervalo de tempo necessário para completar um ciclo, que é uma seqüência completa de indicações semafóricas - verde, amarelo e vermelho - para todas as aproximações. Na seqüência são apresentadas as definições de ciclo ótimo e do verde em semáforos isolados.

\subsubsection{Ciclo ótimo}

Segundo Ferraz (2005) a duração ótima do ciclo proposta por Webster (1958) é aquela que minimiza o atraso médio experimentado pelos veículos na interseção. $O$ valor do ciclo ótimo deve ser calculado pela seguinte expressão empírica:

$C o=\frac{1,5 L+5}{1-Y}$

Sendo:

Co: Duração do ciclo ótimo em $\mathrm{s}$

$L:$ Tempo total perdido no ciclo em $\mathrm{s}$

$Y=\sum y_{c}^{i}$ : somatória das taxas de ocupação críticas das fases/subfases veiculares críticas.

As fases/subfases veiculares críticas são aquelas que apresentam o maior valor de Y. No caso de semáforos sem foco com lente seta, não há problema na identificação das fases/subfases críticas, pois só existe uma trajetória. No caso de semáforos com 
lente seta, é necessário comparar as várias trajetórias possíveis para descobrir as fases/subfases críticas.

\subsubsection{Repartição do verde}

A divisão (repartição) do verde efetivo entre as diversas fases do semáforo deve ser proporcional às taxas de ocupação crítica das mesmas para que o atraso médio global dos veículos no cruzamento resulte mínimo (Ferraz, 2005). Assim a expressão para o cálculo dos verdes efetivos é a seguinte:

$G e_{i}=\frac{y_{c}^{i}}{\sum_{i} y_{c}^{i}} * G e$

Sendo:

$G e_{i}:$ Verde efetivo da fase $i$

$y_{c}^{i}$ : Taxa de ocupação crítica da fase $i$

Ge: Verde efetivo total do ciclo $(G e=C-L)$

Com a distribuição dos tempos de verde proporcional às taxas de ocupação críticas, os índices de congestionamentos nas faixas críticas das fases críticas resultam iguais, ou seja, na expressão:

$x_{1}^{c}=x_{2}^{c}=x_{3}^{c}=x_{j}^{c}=x_{j}^{c}$

A duração dos verdes reais das diversas fases é determinada através da expressão abaixo:

$G_{i}=G e_{i}-l_{i}+L_{i}$ 
Sendo:

$G_{i}$ : Duração real do verde

$G e_{i}:$ Verde efetivo

$l_{i}$ : Período entreverdes

$L_{i}:$ Tempo total perdido na fase

Por razões de segurança e psicológicas (comportamento dos usuários), recomendase: 30 s $\leq \mathrm{C} \leq 120$ seg (excepcionalmente 140seg). Deve-se arredondar o valor de $\mathrm{C}$ obtido com a expressão de Webster para cima para um número múltiplo de 5.

Também recomenda-se que $G_{i} \geq 10$ segundos, quando não for crítica a travessia de pedestres. Caso contrário deve-se utilizar a seguinte expressão para cálculo do verde mínimo:

$G_{i}^{\text {min }}=\frac{L}{V p}+T s$

Sendo:

$L$ : Largura da via a ser cruzada em $\mathrm{m}$

$V p$ : Velocidade de caminhada dos pedestres em $\mathrm{m} / \mathrm{s}$ e

Ts: Intervalo estabelecido à luz da segurança e da capacidade necessária na travessia. 
Nas aplicações práticas adotar: $=V p \quad 1,4 \mathrm{~m} / \mathrm{s}$ e $T s=2-5$ segundos em função da quantidade de pedestres (2 segundos no caso de poucos pedestres e 5 segundos quando se trata de grandes concentrações de pedestres).

O vermelho piscante do semáforo de pedestres deve ser igual a $L / V p$.

Ferraz (2005) afirma que como no mundo real os fluxos de veículos variam ao longo do tempo, o ideal é utilizar controladores de semáforos atuados pelo tráfego, os quais permitem variar a duração do ciclo e dos tempos de verde em função das flutuações momentâneas dos fluxos de veículos, que são detectadas por dispositivos especiais usualmente colocados sob o pavimento das vias. Contudo, como os controladores atuados e os detectores custam muito caro, a utilização de controladores que permitem variar o ciclo e a repartição de verde ao longo do dia de acordo com programação prévia, e que são muito mais baratos, têm desempenho plenamente satisfatório.

Esse método empírico encontra respaldo no gráfico da figura 2.8 apresentado por Webster (1958) e comprovado por Françoso (1990), que mostra que pequenas variações no tempo de ciclo não afetam significativamente a demora média dos veículos no semáforo, sobretudo se a variação for para mais. Em termos numéricos: valores do ciclo entre 0,75 -Co- 1,50.Co conduzem à, no máximo, 10 a $20 \%$ de acréscimo da demora mínima ( $\mathrm{d}=1,10$ a 1,20 minutos) (Ferraz, 2005). 


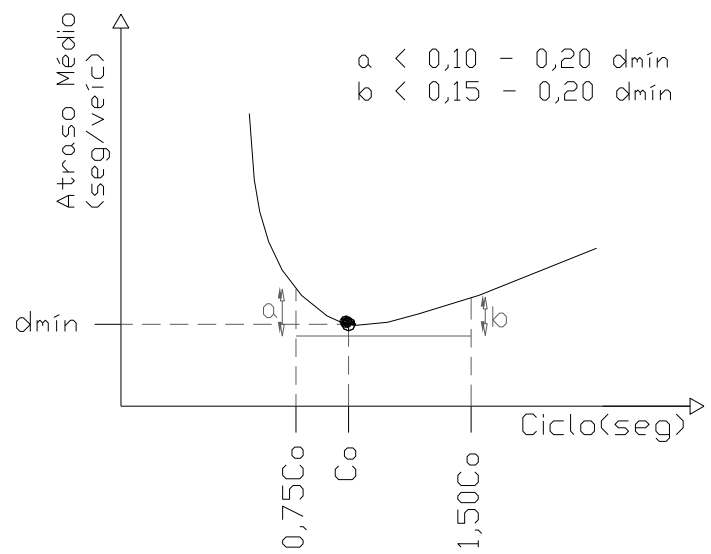

Figura 2. 8 - Atraso médio num semáforo em função da duração do ciclo (Fonte: Ferraz, 2005)

\subsection{OBSERVAÇÕES COMPLEMENTARES}

A seguir são apresentadas algumas observações complementares acerca do nível de serviço para cruzamentos semaforizados, repartição do verde e generalizações do conceito de ciclo ótimo.

\subsubsection{Nível de serviço para cruzamentos semaforizados}

Conforme Ferraz (2005) o parâmetro proposto pelo HCM - 2000 para caracterizar a qualidade da operação (nível de serviço) nos cruzamentos semaforizados é o atraso médio experimentado pelos veículos. 
A classificação preconizada é mostrada na Tabela 2.1.

Tabela 2.1 - Nível de serviço $x$ atraso médio

\begin{tabular}{|c|c|c|}
\hline Nível de serviço (NS) & Qualidade da operação & Valores do atraso médio (seg) \\
\hline A & Ótima & $d \leq 10,0$ \\
\hline B & Boa & $10,0<d \leq 20,0$ \\
\hline C & Regular & $20,0<d \leq 35,0$ \\
\hline $\mathrm{D}$ & Ruim & $35,0<d \leq 55,0$ \\
\hline$E$ & Muito ruim & $55,0<d \leq 80,0$ \\
\hline $\mathrm{F}$ & Péssima (inaceitável) & $d>80.0$ \\
\hline
\end{tabular}

\subsubsection{Repartição do verde}

De acordo com Ferraz (2005) a divisão do verde efetivo proporcionalmente às taxas de ocupação, como visto, conduz ao menor atraso global dos veículos no cruzamento e na igualdade dos índices de congestionamento das faixas críticas das diversas fases. Isso não implica, contudo, que os valores médios do atraso resultem iguais nas faixas críticas.

O HCM-2000 recomenda que o verde efetivo deve ser distribuído de modo a que os atrasos médios nas faixas críticas resultem próximos, a que os níveis de serviço das faixas críticas de cada fase sejam os mesmos. Para se conseguir isso são necessárias algumas iterações no processo de cálculo dos tempos de verde. 


\subsubsection{Generalização do conceito de ciclo ótimo}

Como visto, a metodologia de Webster (1958) propõe uma expressão para o ciclo que minimiza o atraso médio dos veículos no cruzamento, visando o conforto (comodidade) dos passageiros (Ferraz, 2005).

$\mathrm{Na}$ realidade, é necessário contemplar também outros aspectos na escolha da duração do ciclo, como o número de paradas (também ligado ao conforto dos passageiros), o consumo de combustível (ligado à conservação de energia), a emissão de poluentes (ligada à preservação do meio ambiente), etc. Na Figura 2.9 são mostradas curvas típicas do comportamento dos parâmetros atraso, número de paradas, consumo de combustível e emissão de poluentes em função da duração do ciclo.

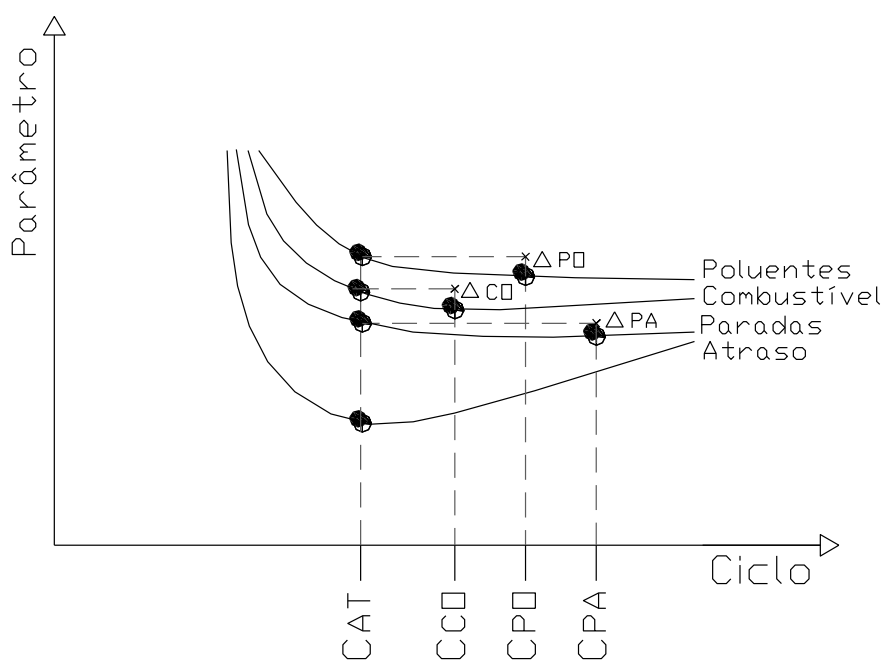

Figura 2. 9 - Variação típica dos principais parâmetros em função do ciclo.

(Fonte: Ferraz, 2005)

As seguintes conclusões relevantes podem ser depreendidas com base na Figura 2.9: 
- O tempo médio parado e o atraso diminuem com o aumento do ciclo, passam por um mínimo e depois aumentam. O valor do ciclo correspondente ao mínimo valor do tempo parado (ciclo ótimo com relação ao tempo parado $-\mathrm{C}_{\mathrm{TP}}$ ) é um pouco menor do que o ciclo ótimo relativo ao atraso $\left(\mathrm{C}_{\mathrm{AT}}\right)$.

- O número de paradas diminui com o aumento do ciclo e depois permanece constante. $\mathrm{O}$ valor do ciclo a partir do qual o número de paradas permanece constante e igual ao mínimo $\left(\mathrm{C}_{\mathrm{PA}}\right)$ é maior do que o ciclo ótimo correspondente ao atraso.

- Como o consumo de combustível e a emissão de poluentes são função do tempo parado e do número de paradas (devido à aceleração e à desaceleração), as durações do ciclo correspondentes aos mínimos valores desses parâmetros estão entre os valores ótimos relativos ao tempo parado e o número de paradas. Os valores ótimos correspondentes ao consumo de combustível e a emissão de poluentes são referidos, respectivamente, por $\mathrm{C}_{\mathrm{co}}$ e $\mathrm{C}_{\mathrm{PO}}$.

- O ciclo ideal, portanto, está entre o ciclo que minimiza o tempo parado e o ciclo a partir do qual o número de paradas é constante e igual ao mínimo. Isso corresponderia a algo como minimizar um parâmetro definido em função do atraso e do número de paradas, que, inclusive, já é utilizado em alguns simuladores de tráfego. A expressão a seguir expressa matematicamente a idéia:

$I=a+K \cdot p$

Sendo: 
I: Índice de desempenho a ser minimizado

$a$ : Atraso médio

$K$ : Fator de penalidade associado a cada parada expresso em unidades de tempo

$a$ : Número médio de paradas

A utilização do ciclo que minimiza o atraso não leva a grandes diferenças nos valores dos outros parâmetros em relação aos seus ciclos ótimos. Assim, a utilização do ciclo ótimo fornecido pela expressão de Webster é satisfatória na prática.

\subsection{Arranjo físico}

No Brasil, não existe um manual específico sobre o posicionamento de grupos focais e colunas de sustentação para elaboração de projetos de sinalização semafórica. 0 manual de sinalização semafórica - Volume V do Departamento Nacional de Trânsito - Denatran ainda não foi publicado. O Manual de Semáforos existente, publicado pelo Denatran em 1979 trata da programação dos tempos semafóricos e aborda critérios para colocação ou não de um semáforo em um cruzamento, porém não aborda a questão do seu arranjo físico. Cucci Neto (1999) aborda alguns aspectos importantes sobre arranjo físico como as vantagens e desvantagens da colocação das colunas de sustentação de semáforos antes ou após o cruzamento, Como podemos notar na Figura 2.10 abaixo: 


\begin{tabular}{|c|c|c|}
\hline & Antes do cruzamento & Após o cruzamento \\
\hline Vantagens & $\begin{array}{l}\text { - melhor visibilidade da sinalização } \\
\text { pela menor distância entre os focos } \\
\text { e a linha de retenção; } \\
\text { - maior respeito ao semáforo, } \\
\text { pela impossibilidade de } \\
\text { visualização das cores dos focos } \\
\text { das outras aproximações; } \\
\text { - maior respeito pela faixa de } \\
\text { pedestres, pois o avanço sobre ela } \\
\text { dificulta a visualização dos focos }\end{array}$ & $\begin{array}{l}\text { - mantém o motorista informado da } \\
\text { condição das cores a ele dirigidas mesmo } \\
\text { após a passagem pela retenção (não } \\
\text { existe o "vôo cego"); } \\
\text { - é o padrão na maior parte das cidades } \\
\text { brasileiras; } \\
\text { - melhor visibilidade para os primeiros da } \\
\text { fila; } \\
\text { - racionalidade no uso de colunas (uma } \\
\text { mesma coluna pode sustentar braços } \\
\text { projetados voltados para mais de uma } \\
\text { aproximação) e grupos focais. }\end{array}$ \\
\hline Desvantagens & $\begin{array}{l}\text { - pode transmitir insegurança ao } \\
\text { motorista em cruzamentos cuja } \\
\text { transversal é muito larga, pois ele } \\
\text { estará atravessando-a sem a } \\
\text { informação das cores do semáforo } \\
\text { ("vôo cego"); } \\
\text { - exige um número maior de grupos } \\
\text { focais, pois há necessidade de } \\
\text { colocação de grupos repetidores a } \\
\text { baixa altura para visualização dos } \\
\text { primeiros da fila; } \\
\text { - não é o padrão na maior parte } \\
\text { das cidades brasileiras; } \\
\text { - exige, também, de um modo } \\
\text { geral, um maior número de } \\
\text { elementos de sustentação, pela } \\
\text { dificuldade de aproveitamento de } \\
\text { uma mesma coluna para suportar } \\
\text { braços projetados paca para } \\
\text { aproximaços diferentes. }\end{array}$ & $\begin{array}{l}\text { - permite, na maioria dos casos, que os } \\
\text { motoristas se baseiem nas cores dos } \\
\text { outros movimentos, comportamento que } \\
\text { pode ser um gerador de acidentes; } \\
\text { - a visibilidade é reduzida pela maior } \\
\text { distância entre os grupos focais e a linha } \\
\text { de retenção. }\end{array}$ \\
\hline
\end{tabular}

Figura 2. 10 - Vantagens e desvantagens das colunas e grupos focais antes e depois do cruzamento. Fonte - Cucci Neto (1999)

Segundo Cucci Neto (1999), por conta da falta de uma norma nacional, o posicionamento de colunas no Brasil varia de cidade para cidade. O autor chama a atenção ainda para a padronização: "Vale lembrar que a decisão por um ou outro arranjo físico deverá levar em conta também um dos fatores básicos para o sucesso 
de qualquer tipo de sinalização viária - a padronização" e baseado na sua experiência descreve algumas recomendações de ordem prática quanto a segurança como: colocação de pelo menos dois grupos para cada grupo semafórico; cuidados com os luminosos de publicidade; posição da lente - as lentes de focos de melhor qualidade possuem internamente uma série de ranhuras direcionais e tem uma posição ideal de instalação no grupo focal; lente seta - o uso da lente seta diminui a luminosidade do foco semafórico, problema que vai se acentuando com o passar do tempo, devido ao acúmulo de poeira e grupos a led - o mais recente avanço tecnológico no campo dos grupos focais é a utilização de diodos emissores de luz (conhecidos como "leds") no lugar das lâmpadas incandescentes normais. Os grupos a led têm várias vantagens, entre elas as principais são a melhor visibilidade e o menor consumo de energia. 


\section{PRINCIPAIS MDDELDS DE GRUPRS FロCAIS SEMÁFロRICDS VEÍCULARES EMPREGADOS ND PAÍs}

\subsection{Considerações iniciais}

Os focos que constituem o grupo focal de um semáforo, de acordo com o Código de Trânsito Brasileiro (2008) tem forma circular e diâmetro de $200 \mathrm{~mm}$ ou de $300 \mathrm{~mm}$. Focos de 200 mm são em geral utilizados em grupos focais situados na lateral da via posicionados a baixa altura e, consequentemente, mais próximos dos olhos dos condutores. Quando o grupo focal é posicionado projetado sobre a via a alturas maiores, é mais indicado empregar focos de $300 \mathrm{~mm}$, pois a distância dos olhos dos condutores é maior.

O acendimento das indicações luminosas deve acontecer na seguinte seqüência: verde, amarelo, vermelho, retornando ao verde. 
Os grupos focais veiculares contêm em geral três focos com indicações luminosas, conforme seqüência estabelecida na Figura 3.1.

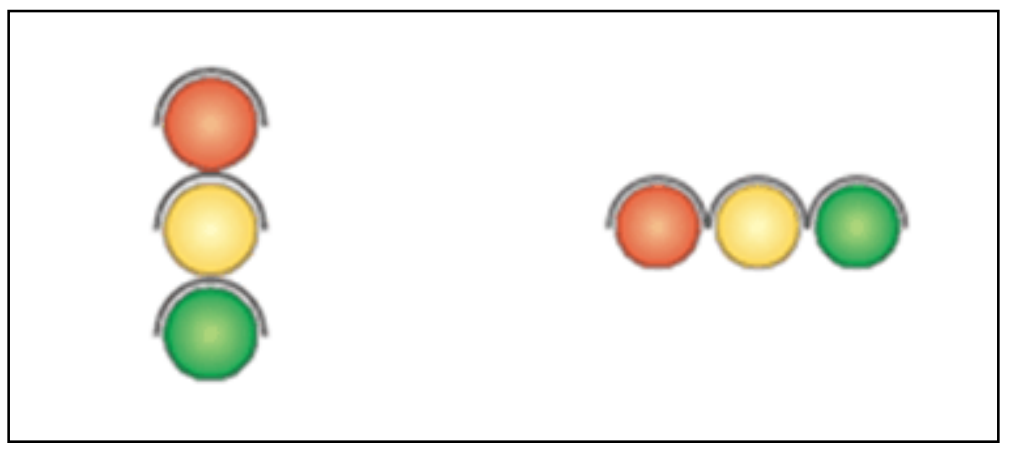

Figura 3. 1- Disposição das indicações luminosas

Para efeito de segurança recomenda-se utilizar no mínimo dois conjuntos de grupos focais por aproximação, ou utilizar um conjunto de grupo focal composto de dois focos vermelhos, um amarelo e um verde.

A Figura 3.2 indica como é feita a sinalização de direção controlada, caso em que são utilizadas lentes com seta.

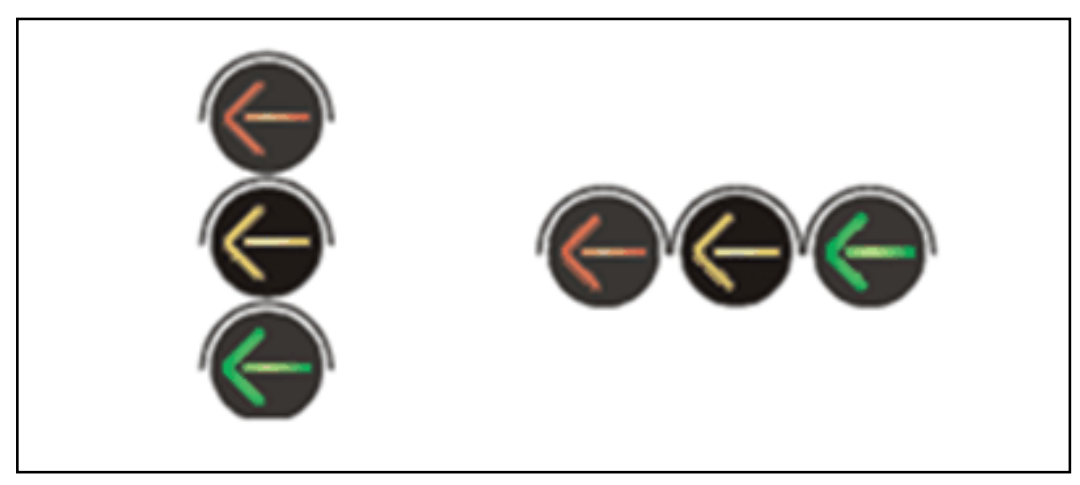

Figura 3. 2 - Semáforo dotado de lente seta. 


\subsection{Modelos de grupos focais empregados no Brasil}

\subsubsection{Modelo padrão}

O modelo de grupo focal padrão em semáforos é aquele indicado pelo Código de Trânsito Brasileiro. O grupo focal é composto pelas luzes vermelha, amarela e verde. Esse modelo de semáforo é encontrado sem anteparo e com anteparo na parte de trás do grupo focal.

A Figura 3.3 mostra foto de um grupo focal semafórico sem anteparo na parte de trás; a Figura 3.4, com anteparo.

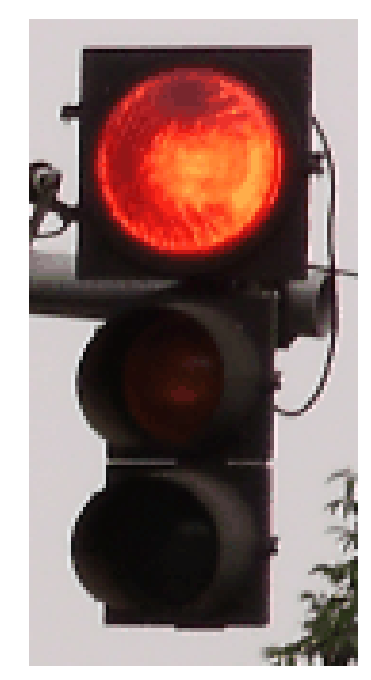

Figura 3. 3 - Grupo focal semafórico sem anteparo na parte de trás 


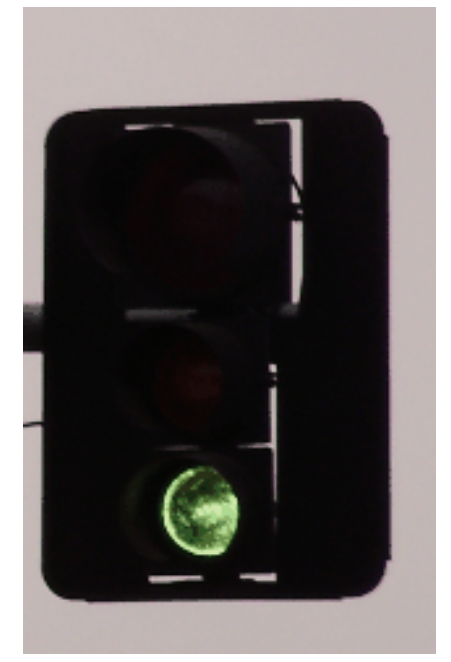

Figura 3. 4 Semáforo com anteparo na parte de trás

\subsubsection{Modelos com informador do tempo de verde/vermelho restante}

Os principais modelos de grupo focal com informador de tempo de verde/vermelho restante são descritos e ilustrados a seguir.

\section{- Modelo 1}

A indicação do tempo de verde/vermelho restante é feito por intermédio de focos com tamanho normal com luzes que vão se apagando acima do foco usual que se mantém aceso, como utilizado em alguns semáforos na cidade de São Carlos - SP. 
A Figura 3.5 mostra uma fotografia deste modelo de semáforo.

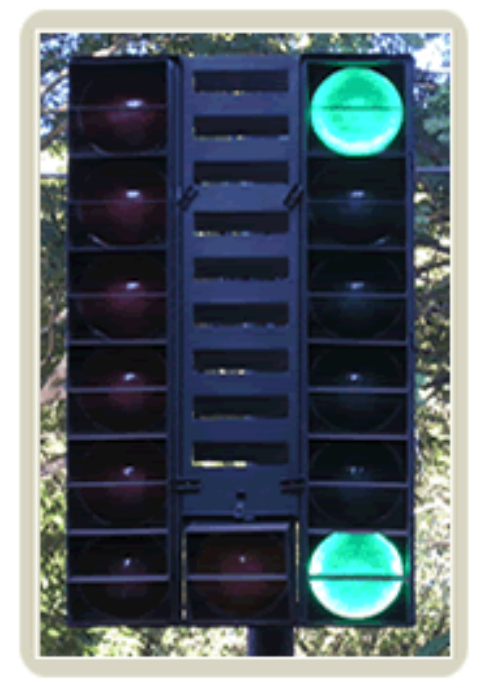

Figura 3. 5 Semáforo modelo 1

- Modelo 2

A indicação do tempo de verde/vermelho restante é feito por intermédio de focos de pequeno tamanho com luzes que vão se apagando situados ao lado dos focos de tamanho normal que se mantém acesos conforme o padrão convencional, como utilizado em alguns semáforos na cidade de Ribeirão Preto - SP. 
A Figura 3.6 mostra uma fotografia deste modelo de semáforo.

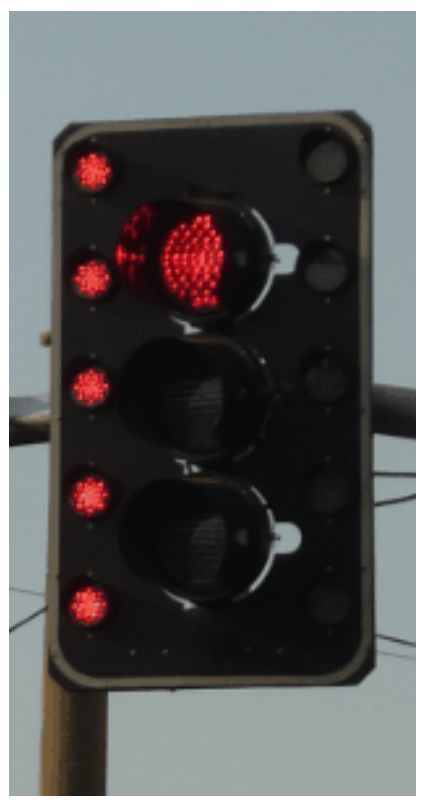

Figura 3. 6 Semáforo modelo 2

- Modelo 3

A indicação do tempo de verde/vermelho restante é feito por intermédio de visor contendo informação digital ao lado dos focos de tamanho normal, posicionados na horizontal, que se mantém acesos conforme o padrão convencional, como utilizado em alguns semáforos na cidade de Piracicaba. 
A Figura 3.7 mostra uma fotografia deste modelo de semáforo.

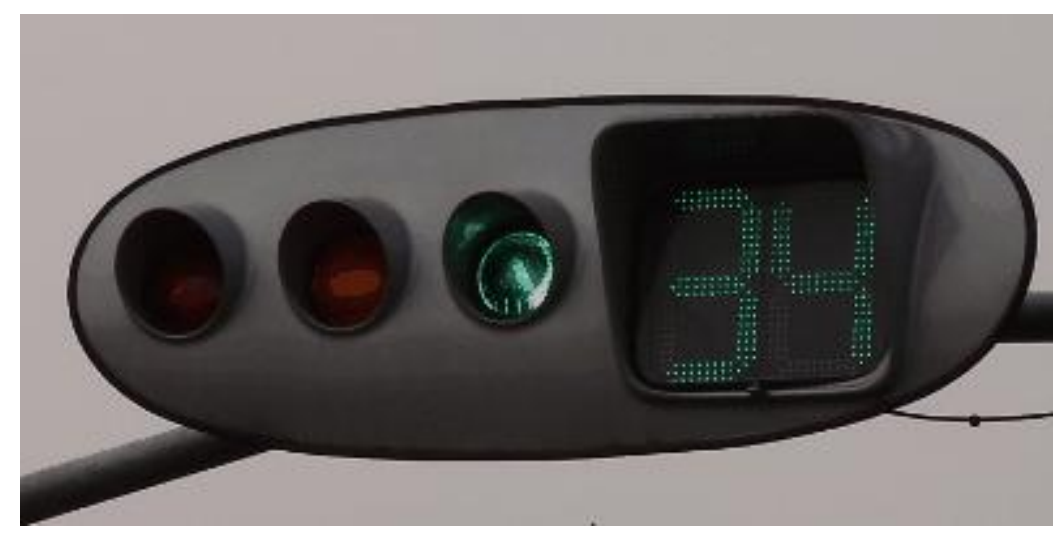

Figura 3. 7 Semáforo Modelo 3 


\section{MÉTロDQ PARA AVALIAÇÃ \\ DA CAPACIDADE EM SEMÁFロRロS}

\subsection{Contextualização}

Existem vários métodos para avaliação da capacidade, dentre eles o método proposto pelo Australian Road Research Board Ltd (2003), o método do DENATRAN e do HCM - 2000. Todos esses métodos foram estudados e analisados para servir de instrumento deste trabalho. Com o conhecimento desses métodos e para alcançar o objetivo de obter a capacidade da interseção foi desenvolvida uma nova metodologia que será descrita juntamente com os métodos citados acima.

\subsection{Método do Australian Road Research Board Ltd}

O método apresentado pelo Australian Road Research Board Ltd (2003) descreve como medir o fluxo de saturação e o tempo perdido. O mesmo cita que um simples método de medir o fluxo de saturação em veículos unitários sem considerar a composição do tráfego pode ser praticado usando um formulário como mostrado na Tabela 4.1. O método consiste em contar os veículos que partiram da fila durante três intervalos distintos (coluna 1 a 3 da Tabela 4.1). 
(a) Primeiro intervalo: corresponde aos 10 primeiros segundos do período de verde

(b) Segundo intervalo: corresponde ao resto do período de verde (descontados os 10 segundos iniciais), enquanto saturado, ou seja, enquanto a fila não for dissipada

(c) Terceiro intervalo: corresponde aos períodos depois do fim do verde, ou seja, período de amarelo e vermelho total

Os veículos são contados conforme cruzam a linha de retenção, porém é preciso uma tomada de decisão, observando o fim da fila, quando o período de saturação termina.

Deste modo, o tempo de saturação (coluna 4 da Tabela 4.1) deve ser registrado como o tempo para "limpar" os veículos que estão parados durante o período de vermelho bem como os veículos que chegam atrás da fila e estão parados durante o período de verde. O número desses veículos é marcado na coluna 2. Contudo, o veículo que não estiver parado é excluído da conta. O período de saturação inclui o primeiro, mas não o último intervalo. O máximo volume é o tempo de verde (marcado na coluna 5), e ele corresponde ao ciclo saturado total. Se o tempo de saturação é menor que 10 segundos a contagem do ciclo deve ser desconsiderada. Os veículos que partirem no último intervalo deverão ser considerados apenas em condições totalmente saturadas, ou seja, quando a fila ainda existir no fim do período de verde. Se o veículo partir em condições de saturação, esse fato deve ser 
marcado como zero na coluna 3 (local em que o período de verde não está totalmente saturado).

A contagem deve ser repetida para alguns ciclos; esse número de ciclos pode ser considerado como razoável e ser adotado quando o fluxo estiver completamente saturado. No exemplo apresentado no Australian Road Research Board Ltd (2003), foram observados 30 ciclos, dos quais 15 estavam saturados. Como norma geral as observações devem ser feitas separadamente para cada faixa de tráfego. No entanto, de modo a reduzir os custos do trabalho, as observações de faixa de tráfego similarmente operadas devem ter procedimento conjunto.

O fluxo de saturação, em veículos por segundo, $\left(S^{*}\right)$ é dado por:

$$
S^{*}=\frac{X_{2}}{X_{4}-10 * n_{4}}
$$

Sendo:

$X_{2}$ : soma do o de veículos partindo do segundo intervalo de todos os ciclos considerados

$X_{4}$ : soma do tempo de saturação de todos os ciclos considerados, em segundos

$n_{4}: \mathrm{n}^{\circ}$ de ciclos com tempo de saturação igual ou superior a 10 segundos

O fluxo de saturação, em veículos por hora de tempo verde, (s) então é calculado por:

$S=3600 * h$

Sendo: 
$\mathrm{h}=$ headway $(\mathrm{s})$

O tempo perdido no início e fim de cada fase $(\ell)$ é calculado pela expressão:

$\ell=l+10-\frac{1}{S^{*}} *\left(\frac{x_{1}}{n_{1}}-\frac{x_{3}}{n_{3}}\right)$

Sendo:

$l$ : Tempo correspondente ao intervalo de mudança (entreverdes), em segundos

$S^{*}$ : Fluxo de saturação, em veículos por segundo

$x_{1}$ : Soma do número de veículos a partir do primeiro intervalo de todos os ciclos considerados

$n_{1}$ : Número de ciclos considerados

$x_{3}$ : Soma do número de veículos a partir do terceiro intervalo de todos os ciclos completamente saturados

$n_{3}$ : № de ciclos completamente saturados

O tempo de verde efetivo ( $\mathrm{g}$ ) é determinado pela expressão:

$g=l+G-\ell$

Na qual todos os termos já foram previamente definidos, exceto G que é o tempo de verde alocado para a fase em estudo. 
A Tabela 4.1 traz o modelo da tabela usada no método.

Tabela 4. 1 - Fluxo de saturação e tempo perdido

\begin{tabular}{|c|c|c|c|c|c|}
\hline \multirow[b]{2}{*}{ № DE CICLOS } & \multicolumn{3}{|c|}{ FILAS (VEÍCULOS) } & \multirow{2}{*}{$\begin{array}{c}\text { TEMPO DE } \\
\text { SATURAÇÃO } \\
\text { (SEG) }\end{array}$} & \multirow{2}{*}{$\begin{array}{c}\text { TEMPO } \\
\text { DE VERDE } \\
\text { (SEG) }\end{array}$} \\
\hline & $\begin{array}{c}1^{\circ} \\
\text { INTERVALO }\end{array}$ & $\begin{array}{c}2^{\circ} \\
\text { INTERVALO }\end{array}$ & $\begin{array}{c}3^{\circ} \\
\text { INTERVALO }\end{array}$ & & \\
\hline \multicolumn{6}{|l|}{1} \\
\hline \multicolumn{6}{|l|}{2} \\
\hline \multicolumn{6}{|l|}{. } \\
\hline \multicolumn{6}{|l|}{28} \\
\hline \multicolumn{6}{|l|}{29} \\
\hline \multicolumn{6}{|l|}{30} \\
\hline TOTAL & $\mathrm{X} 1=$ & $\mathrm{X} 2=$ & $\mathrm{X} 3=$ & $X 4=$ & $X 5=$ \\
\hline AMOSTRAS & $\mathrm{n} 1=$ & $\mathrm{n} 2=$ & n3= & $\mathrm{n} 4=$ & $\mathrm{n} 5=$ \\
\hline
\end{tabular}

(Fonte: Akçelik, R., 1981)

\subsection{Método do DENATRAN}

O Manual de Sinalização Semafórica da Companhia de Engenharia de Tráfego se São Paulo - CET (2002) descreve o Método do Histograma que consiste na medida do número de veículos que passam pela aproximação em pequenos intervalos de tempo, e objetiva a precisa determinação do fluxo de saturação, aqui denominado (FS), do tempo perdido no início do verde (Tpi) e do tempo aproveitado no final (Taf).

O patamar superior obtido a partir do histograma determina o fluxo de saturação da aproximação. 
O histograma proposto pelo método do DENATRAN, descrito no Manual de Sinalização Semafórica da CET (2002) é apresentado na Figura 4.1.

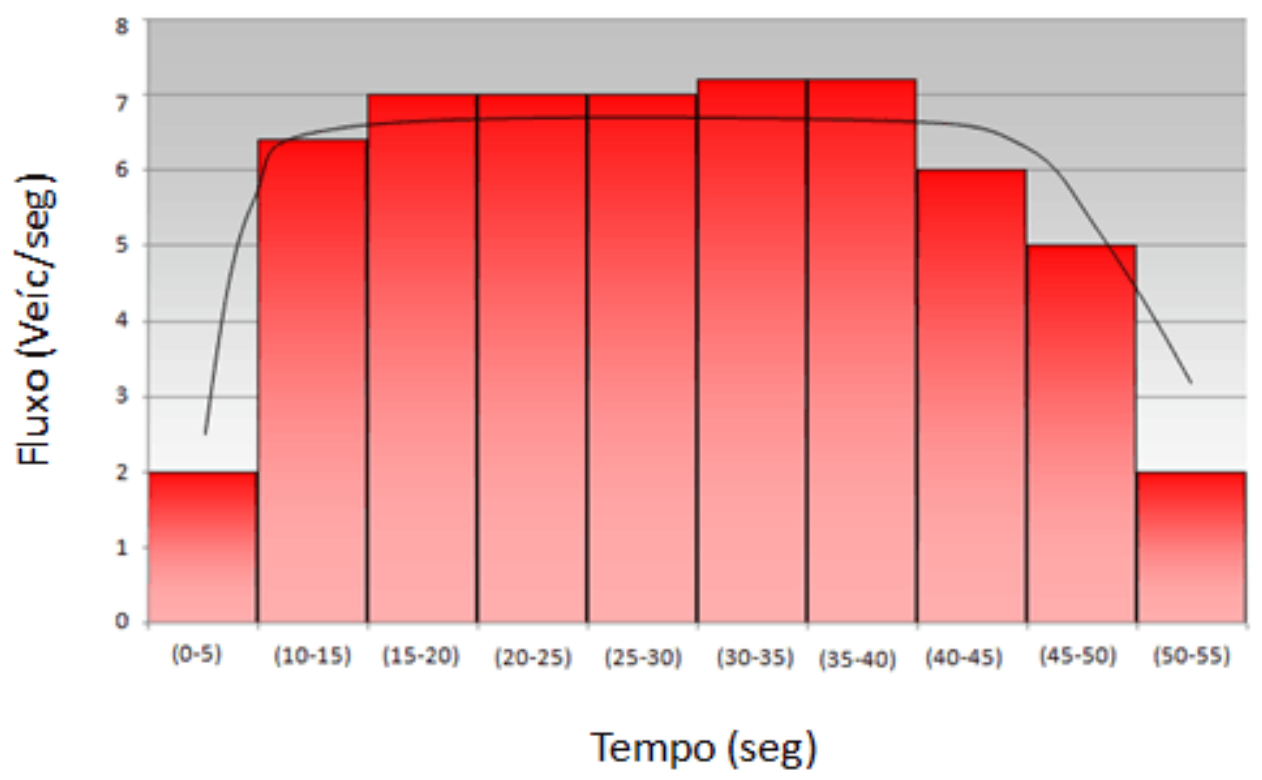

Figura 4. 1- Histograma do método proposto pelo DENATRAN

(Fonte: Manual de Sinalização Semafórica - CET 2002)

A oscilação verificada em torno do valor médio é função do caráter aleatório do fluxo dos veículos (a porcentagem de conversões varia a cada intervalo, os motoristas mantêm espaçamentos e velocidades diversas etc.).

Para que o histograma reflita realmente o fluxo de saturação da aproximação há duas condições essenciais:

- é necessário existir demanda suficiente para que a saída se desenvolva no patamar de saturação durante um período de pelo menos vinte e cinco segundos

- e o trecho à jusante do semáforo tem que absorver totalmente o fluxo descarregado. 
O número de amostras medidas não deve ser inferior a dez.

O termo Tpi mostra o intervalo de tempo que deixa de ser aproveitado desde o início do verde até a efetiva entrada no patamar de saturação.

O termo Taf reflete o intervalo de tempo que realmente foi aproveitado mesmo após o encerramento do período de verde.

Identificado os valores de F e FS, é diretamente calculado o valor da taxa de ocupação y (para o caso em que a demanda D seja igual ao fluxo F):

$Y=\frac{F}{F S}$

O tempo morto, ou seja, o período do ciclo que não pode ser aproveitado para escoamento dos veículos, é calculado por:

$T m=\sum\left(T_{a m}+T_{v m s e g}+T_{p i}+T_{a f}\right)+T_{\text {est.ped }}$

Sendo:

$T_{a m}$ : Tempo de amarelo

$T_{\text {vmseg }}:$ Tempo de vermelho de segurança

$T_{p i}$ : Tempo perdido no início do verde

$T_{a f}:$ Tempo aproveitado no final do verde

$T_{\text {est.ped }}$ : Tempo devido à ocorrência do estágio específico para pedestres 
O termo entre parênteses é calculado pelo somatório dos tempos perdidos em todos os estágios. O segundo termo representa o tempo de estágio específico para pedestres, caso exista.

Quando o estágio de pedestres somente ocorrer mediante acionamento por botoeira, é recomendado calcular um tempo corrigido, o qual leve em consideração a porcentagem de vezes na qual esse estágio realmente ocorrer.

\subsection{Método do HCM - 2000}

O método proposto pelo HCM (2000) calcula o headway médio durante o período de saturação através do headway médio de desmanche da fila em medições do fluxo de saturação "in loco".

Após 10 segundos do início do tempo de verde se inicia o período de saturação e termina quando o pára-choque traseiro do último veículo da fila passa sobre a linha de retenção ainda no tempo de verde.

Primeiramente deve-se determinar uma faixa de tráfego e registrar os seguintes dados:

- tempo em segundos compreendido entre o início do tempo de verde e a passagem do último veículo que entrou na fila quando o sinal mudou para verde.

- tempo do último veículo que entrou na fila antes da abertura do verde deve- se subtrair 10 segundos.

As fórmulas utilizadas pelo HCM (2000) são:

$$
h_{m=} \frac{n-n_{10}}{N-4}
$$


$S=3600 / n$

Sendo:

$\mathrm{h}_{\mathrm{m}}$ : Headway médio em segundo

$n$ : Tempo em segundos do ultimo veículo a entrar na fila

$\mathrm{n}_{10}: 10$ segundos.

$\mathrm{N}$ : Número de veículos na fila.

Segundo o HCM 2000 é necessário que a saída de veículos esteja desimpedida quanto a fatores adversos ao tráfego, como caminhões fazendo carga e descarga, carros fazendo manobras de estacionamento, entre outros, e principalmente que a aproximação esteja liberando o máximo possível de veículos refletindo a real capacidade da via.

\subsection{Método utilizado no trabalho}

Após a análise e estudo dos métodos anteriormente citados, desenvolveu-se um método específico para o presente trabalho.

\subsubsection{Obtenção do fluxo de saturação e tempo perdido no início do verde}

De acordo com a literatura, os intervalos de tempo entre a passagem de veículos consecutivos na linha de retenção em semáforos é maior para os quatro primeiros veículos da fila, conforme indicado na Figura 4.3. 


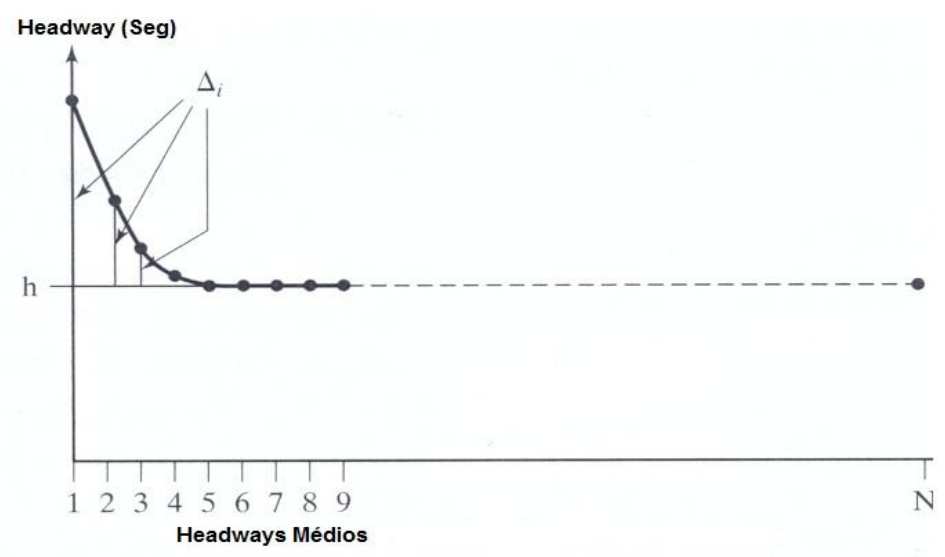

Tabela 4.2 - Headways numa fila de veículos num semáforo
(Fonte: Roess, et al, 2004)

À luz desse fato, formulou-se o método descrito a seguir para a obtenção do fluxo de saturação e do tempo perdido no início de cada fase semafórica.

No momento em que a luz verde iniciava, o cronômetro do pesquisador era disparado. Em seguida eram registrados os instantes em que o para-choque dianteiro do $4^{\circ}$ e $10^{\circ}$ veículos da fila existente passavam pela linha de retenção (observando que 0 10ำ já estava na fila quando surgiu a luz verde para a aproximação).

Uma vez obtidos os instantes anteriormente mencionados, foram utilizadas as seguintes expressões para a determinação das grandezas pesquisadas:

$$
h_{i}=\frac{T_{4}}{4}
$$

$\mathrm{h}_{\mathrm{n}}=\frac{T_{10}-T_{4}}{6}$

$T_{p i}=4 *\left(h_{i}-h_{n}\right)$ 
$S=\frac{3600}{h n}$

Sendo:

$h_{i}$ : Headway médio para os 4 primeiros veículos (s)

$\mathrm{h}_{\mathrm{n}}$ : Headway médio após a passagem do 4º veículo (s)

$T_{10}$ : Instante de passagem do 10ำ veículo da fila (s)

$T_{4}$ : Instante de passagem do 4ํveículo da fila (s)

$T_{p i}:$ Tempo perdido na partida da fila (s)

$s$ : Fluxo de saturação (veíc/h)

\subsubsection{Obtenção do tempo perdido no final da fase}

Quando o tempo de amarelo começava, o cronômetro do pesquisador era disparado. Em seguida, era registrado o instante de passagem do para-choque dianteiro do último veículo da fila (garantido que a fila existia).

Uma vez obtido o instante anteriormente mencionado, foram utilizadas as seguintes expressões para a determinação das grandezas pesquisadas:

$T p f=I-T u$

$I=Y+R t$

Sendo:

Tpf: Tempo perdido no final da fase (s)

I: Entreverdes (s)

$Y$ : Amarelo (s) 
Tu: Instante da passagem do último veículo após o surgimento da luz amarela, ou seja, tempo aproveitado para a passagem após o aparecimento do amarelo (s)

\subsubsection{Determinação do tempo total perdido e da capacidade}

O tempo total perdido em cada fase semafórica corresponde à soma do tempo perdido no início e o tempo perdido no final, ou seja:

$T p=T p i+T p f$

Sendo:

Tp: Tempo total perdido em cada fase semafórica (s)

Tpi: Tempo perdido no início da fase (s)

Tpf: Tempo perdido no final da fase (s)

O tempo total perdido no ciclo corresponde à soma dos tempos totais perdidos em cada fase k, ou seja:

$T P=\sum T p k$

Sendo:

$T P$ : tempo total perdido no ciclo (s)

Tpk: tempo total perdido na fase $\mathrm{k}(\mathrm{s})$

O verde efetivo de cada fase é dado por:

Gek $=G k+I k-T p k$

Sendo: 
Gek: verde efetivo da fase k (s)

$G k$ : verde real da fase $\mathrm{k}(\mathrm{s})$

$I k$ : entreverdes da fase $\mathrm{k}(\mathrm{s})$

Tpk: tempo total perdido na fase $\mathrm{k}(\mathrm{s})$

O verde efetivo total em cada ciclo é dado por:

$G e=\sum G e k=C-T P$

Sendo:

Ge: verde efetivo total do ciclo (s)

Gek: verde efetivo de cada fase k (s)

$C$ : ciclo do semáforo (s)

$T P$ : tempo perdido total do ciclo $(\mathrm{s})=\sum T P k$

A capacidade horária em cada faixa de tráfego $\mathrm{m}$ que se movimenta na fase $\mathrm{k}$ é dada pela expressão:

$C A P m=s . G e k / C$

Sendo:

CAPm: capacidade horária da faixa m (veíc/h)

s: fluxo de saturação da faixa m (veíc/h)

Gek: verde efetivo da fase k (s)

C: duração do ciclo (s)

Admitindo que todas as faixas tenham o mesmo fluxo de saturação, a capacidade de tráfego da interseção durante um ciclo é dado pela expressão: 
$C A P=n \cdot \sum C a m=n \cdot s \cdot G e / C=n \cdot s \cdot(C-T P) / C$

Sendo:

CAP: capacidade horária de tráfego na interseção durante um ciclo (veíc/ciclo)

n: número total de faixas na interseção

CAm: capacidade horária de cada faixa (veíc/h)

$s$ : fluxo de saturação nas diversas faixas (veíc/h)

$G e$ : verde efetivo total do ciclo (s)

$C$ : duração do ciclo (s)

$T P$ : tempo total perdido no ciclo (s)

Para o caso particular do cruzamento de duas vias com sentido único, com apenas uma faixa de tráfego cada uma e considerando $s=1 / h$, resulta na expressão [4.21] para capacidade horária da interseção semaforizada.

$$
C A P=\frac{C-T P}{C} * S=\frac{C-T P}{C} * \frac{3600}{h}
$$

Sendo,

CAP: Capacidade horária da faixa (veíc/h)

C: Duração do ciclo (s)

TP: Tempo total perdido no ciclo (s)

$S$ : Fluxo de saturação

h: headway médio 


\section{AVALIAÇÃ NA SEGURANÇA \\ DE INTERVENÇŨES ND \\ SISTEMA VIÁRID}

\subsection{Considerações iniciais}

As considerações que seguem tem como fonte Ferraz et al (2008).

Para o desenvolvimento de planos/projetos voltados para a segurança viária é importante ter uma estimativa do potencial das diversas ações na redução da acidentalidade, preferencialmente com valores desagregados por tipo de acidente quanto à gravidade: sem vítimas, com vítimas não fatais e com vítimas fatais. Essas informações são fundamentais para direcionar os tipos de planos/projetos a ser desenvolvidos e para selecionar aqueles que apresentam maior potencial para reduzir a acidentalidade e proporcionar os maiores benefícios econômicos.

Para as ações que atuam de forma direta, a confiabilidade das estimativas é maior; nas indiretas, como aquelas que se situam no campo político-administrativo, os erros na previsão são usualmente maiores. As estimativas resultam em geral, mais precisas quando feitas com base nos resultados de ações similares realizadas na mesma cidade ou região, pois fatores como o nível educacional, a cultura, o clima, 
as características do sistema viário, os tipos de veículos utilizados, etc. influem no grau de eficácia das ações.

Nos países desenvolvidos, onde há o monitoramento das ações voltadas para a segurança no trânsito e muitos estudos e pesquisas são realizados, existe disponibilidade de dados (locais, regionais e nacionais) confiáveis sobre o impacto das principais ações na redução da acidentalidade. Nos países não desenvolvidos, em geral, esse tipo de informação é escassa, sendo, muitas vezes utilizados nos estudos dados obtidos em países desenvolvidos, com conseqüente aumento do nível de incerteza da eficácia das ações.

A grande dificuldade para o monitoramento das ações reside em vários fatores: definição do que é acidente, propensão em reportar acidentes, registro incompleto dos acidentes, identificação dos acidentes alvos do tratamento, mudanças de governo que mudam a metodologia de registro de acidentes, regressão para a média, inclusão de outros fatores contribuintes para os acidentes, entre outros.

Também relevante é o fato de que a segurança viária muda com o tempo, assim estudos observacionais comparando o numero de acidentes antes e depois de algum tratamento tem sido instrumento significativo no campo da avaliação da segurança no tráfego. Nesses estudos não se pode assumir que não tendo sido aplicado o tratamento (numa ação voltada para a segurança viária), a segurança no período "depois" poderia ter sido a mesma como no período "antes". Portanto, para avaliar o efeito do tratamento na segurança de alguma entidade é preciso comparar o que poderia ter sido a segurança da entidade no período antes se o tratamento 
não tivesse sido aplicado, com o que foi a segurança da entidade tratada no período depois.

Assim, a lógica básica para qualquer pergunta acerca do efeito de qualquer tratamento está na seguinte comparação:

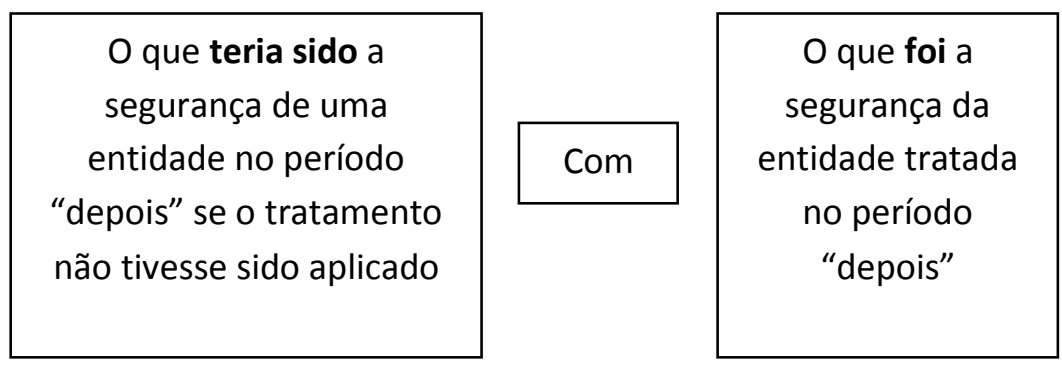

(Fonte: Hauer, 1997)

Figura 5. 1 - Comparação da segurança

Outra dificuldade no monitoramento da segurança é que os estudos do tipo antes e depois são analisados após o evento e não podem ser reproduzidos em laboratório.

Segundo Cochran, 1983 apud Hauer,1997, os estudos observacionais têm duas características essenciais:

1) O objetivo é estudar os efeitos causais de certos agentes, procedimentos, tratamentos, ou programas.

2) Por uma razão ou outra, o pesquisador não pode usar a experimentação controlada, isto é, ele não pode impor sobre um objeto, ou retirar do objeto, um procedimento ou tratamento cujos efeitos deseja descobrir, ou não pode designar aleatoriamente o objeto a procedimentos diferentes. 
Dessa forma, para a realização de um estudo do tipo antes e depois é necessário prever o que teria sido a segurança de uma entidade no período depois se 0 tratamento não tivesse sido aplicado com o que foi a segurança no período depois.

Existem vários métodos de previsão para a avaliação do impacto na segurança de intervenções viárias, sendo que cada um deles resulta em valores diferentes para a previsão - o que poderá levar a resultados antagônicos.

Segundo Hauer (1997), a existência de muitos métodos diferentes de predição e correspondentemente as muitas estimativas de mudança na segurança é desconcertante. Esta é uma das razões pela qual a literatura profissional abunda com achados conflitantes. Para Hauer (1997) o melhor método é aquele que prediz melhor. Para predizer bem devem ser respondidas várias questões estratégicas:

(a): Como levar em conta os fatores causais que afetam a segurança, que são mensurados e a influência que têm ou que pode ser conhecida. Com isso, por exemplo, sabe-se que o volume afeta a segurança. Para alguns casos têm-se uma idéia da relação entre o volume e a segurança. Se a informação sobre o volume está disponível antes e depois do tratamento, deve-se considerá-lo quando se quer predizer o que teria sido a segurança no período depois se o tratamento não tivesse sido aplicado. Esta abordagem é uma modelagem.

(b): Como considerar os fatores remanescentes que afetam a segurança mais que não foram mensurados ou a influência não é conhecida. A influência desses fatores pode ser considerada através da extrapolação da tendência ao longo do tempo e utilizando os grupos de comparação. A esperança é, com o aumento do conhecimento, através de pesquisas e de estudos dos fatores que afetam a segurança, mais fatores que hoje são considerados na questão "b" sejam considerados no futuro na questão "a".

(c) Questão c: Como considerar uma tendência selecionada. O histórico de acidentes durante o período antes é uma pista importante do que teria sido a segurança no período depois. Entretanto, o mesmo histórico de acidentes pode também ser uma das razões pelas quais o tratamento foi aplicado. Isto faz com que as predições estejam sujeitas a uma tendência, a qual tem um nome: regressão para a média. 
(d): Como considerar as mudanças no registro dos acidentes. O grau pelo qual os acidentes são reportados, muda de tempos em tempos, de lugar para lugar. Ao menos que a mudança é estimada, não se pode separar o efeito do tratamento do efeito nas mudanças de registro dos acidentes.

Os métodos de previsão mais conhecidos no âmbito da engenharia de tráfego são os seguintes: utilizar o número de acidentes do último ano do período anterior; utilizar a média dos últimos três anos do período anterior; tendo uma série temporal relativamente longa utilizar uma equação de regressão para o ano posterior; e os modelos de regressão. Cada um desses métodos possui pontos positivos e negativos. A utilização de um ou outro método depende da disponibilidade de recursos e dados, bem como da finalidade e precisão que se pretende.

Nesta dissertação serão utilizados dois métodos de previsão propostos por Hauer (1997), a saber: Método Antes - Depois Ingênuo e Método usando Grupos de Comparação. A utilização desse método se deu pelo fato de se tratar de um estudo com mais embasamento teórico e menor teor intuitivo. Esses métodos são descritos a seguir.

\subsection{Método Antes - Depois Ingênuo}

Segundo Hauer (1997), um estudo observacional Antes - Depois, consiste em comparar, para uma entidade, o número de acidentes do período "antes" com o número de acidentes do período "depois".

De acordo com a metodologia proposta por Hauer (1997) a contagem de acidentes do período "antes" é usada para prever o que teria sido a contagem esperada de acidentes do período "depois" se o tratamento não tivesse sido implementado. Esta forma de prever reflete uma crença ingênua e geralmente irreal de que a passagem 
do tempo (a partir do período "antes" para o "depois") não esta associada com mudanças que afetaram a segurança da entidade sob observação. Hauer (1997) chama este, então, de estudo "Antes - Depois Ingênuo". E acrescenta que apesar da sua falha óbvia, o estudo Antes - Depois Ingênuo merece minuciosa discussão, pois o método é um ponto de partida natural para o debate, podendo-se discutir seus méritos e deficiências com clareza, e por ainda ser muito freqüentemente encontrado na literatura especializada e também pelo fato de que nenhum outro projeto de estudo pode alcançar à precisão estatística que é atingível em um estudo Antes - Depois Ingênuo.

Alguns fatores, como o tipo de condutor ou a frota de veículos, mudam apenas gradualmente, portanto, quanto menores os períodos "antes" e "depois", menor seria a influência de tais mudanças graduais e mais claramente discernível o efeito do tratamento. O mesmo não é verdadeiro para fatores como adversidades do clima, greves policiais ou do transporte público, grandes eventos, falhas de energia elétrica e similares, os quais podem ser muito diferentes em anos sucessivos. Assim, o uso de curtos períodos "antes" e "depois" não diminui a preocupação com a influência de fatores que mudam inesperadamente.

O estudo Antes - Depois Ingênuo estima uma mistura do que é devido ao tratamento e o que é causado por outras influências. Esse fato deve ser explicitado sempre que os resultados de um estudo Antes - Depois Ingênuo são publicados. A seguir é descrita a metodologia relativa ao Estudo Antes - Depois Ingênuo de acordo com Hauer (1997).

As variáveis utilizadas são as seguintes: 
$\pi$ : número esperado de acidentes de uma entidade específica, em um período "depois" se não tivesse sido tratada; é o que tem que ser previsto.

$\lambda$ : número esperado de acidentes da entidade no período "depois", é o que tem que ser estimado.

O efeito do tratamento sobre a segurança é avaliado pela comparação de $\lambda$ e $\pi$. Para comparar os dois, deve-se analisar:

$$
\delta=\pi-\lambda
$$

Sendo:

$\delta$ : redução do período "depois" do número esperado de acidentes ou severidade do acidente.

$$
\theta=\lambda \pi
$$

Sendo:

$\theta$ : razão entre o que a segurança foi com o tratamento e a que teria sido sem $o$ tratamento ("índice de eficácia").

Quando algum tratamento é implementado em entidades, elas são numeradas 1, $2, \ldots, j, \ldots, n$. Durante os períodos "antes" as contagens de acidente são chamadas $\mathrm{K}$ (1), $K(2), \ldots, K(n)$ e durante os períodos "depois" as contagens de acidente são chamadas $L(1), L(2), \ldots, L(n)$. A duração dos períodos "antes" e "depois" pode ser diferente de entidade para entidade. Define-se a "razão de durações" como:

$$
r_{d}(j)=\frac{\text { Duração do período depois para a entidade } j}{\text { Duração do período antes para a entideade } j}
$$


As estimativas dos parâmetros $\hat{\lambda}$ e $\hat{\pi}$, e das variâncias $\operatorname{VÂ} R\{\hat{\lambda}\}$ e $\operatorname{VÂ} R\{\hat{\pi}\}$ para um estudo ingênuo são apresentadas nas Tabelas 5.1 e 5.2. as quais são referentes as etapas 1 e 2 do método.

Tabela 5. 1 - Estimativa quando nem todos os $r_{d}(j)$ são os mesmos

Estimativas dos Parâmetros

ETAPAS 1
$\hat{\lambda}=\Sigma L(j)$
$\hat{\pi}=\operatorname{srd}(j) K(j)$

Tabela 5. 2 - Estimativa quando todos os $r_{d}(j)$ são os mesmos

\begin{tabular}{cc}
\hline $\begin{array}{c}\text { Estimativas dos Parâmetros } \\
\text { ETAPAS 1 }\end{array}$ & Estimativas das Variâncias \\
\hline$\hat{\lambda}=\Sigma L(j)$ & $V \hat{A} R\{\hat{\lambda}\}=\Sigma L(j)$ \\
$\hat{\pi}=r d \Sigma K(j)$ & $V \hat{A} R\{\hat{\pi}\}=r d^{2} \Sigma K(j)$ \\
\hline
\end{tabular}

A Tabela 5.3 apresenta as fórmulas para as etapas 3 e 4 onde são obtidos os parâmetros de $\delta$ e $\theta$ e suas variâncias

Tabela 5.3 - Etapas 3 e 4

\begin{tabular}{l}
\hline$\delta=\pi-\lambda$ \\
$\operatorname{VAR}\{\hat{\delta}\}=\operatorname{VAR}\{\hat{\pi}\}+\operatorname{VAR}\{\hat{\lambda}\}$ \\
$\hat{\theta}=(\lambda / \pi) /\left[1+\operatorname{VAR}\{\hat{\pi}\} / \pi^{2}\right]$ \\
$\operatorname{VAR}\{\hat{\theta}\} \approx \theta^{2}\left[\left(\operatorname{VAR}\{\hat{\lambda}\} / \lambda^{2}\right)+\left(\operatorname{VAR}\{\hat{\pi}\} / \pi^{2}\right)\right] /\left[1+\operatorname{VAR}\{\hat{\pi}\} / \pi^{2}\right]^{2}$
\end{tabular}




\subsection{Método Antes - Depois utilizando grupos de comparação}

O objetivo desse estudo é fornecer uma abordagem unificada para a interpretação estatística de todas as variantes do estudo observacional "antes e depois" (HAUER, 1997) O estudo também consiste em quatro etapas básicas semelhante ao método anterior. Um resumo do método é descrito a seguir.

A idéia central do uso de um grupo de comparação - G-C é: identificar um grupo de entidades que permaneceu sem tratamento, e que são semelhantes às entidades tratadas. As entidades tratadas formam o "grupo de tratamento". As entidades não tratadas são o "grupo de comparação".

Define-se:

$r_{c}$ : "razão de comparação"; a razão entre o número esperado de acidentes no período "depois" e o número esperado de acidentes no período "antes" no grupo de comparação.

$\pi=$ (número esperado de acidentes "antes" no grupo de tratamento) $\times r_{c}$ A atribuição de entidades para o grupo de tratamento não é feita aleatoriamente. Mesmo com grupos grandes de entidades não há nenhuma garantia de que o número esperado de acidentes de um grupo de tratamento tenha mudado da mesma maneira que no grupo de comparação. É prudente falar sempre de "estudos observacionais" e de "grupos de comparação".

Em um estudo observacional Antes - Depois envolvendo um grupo de tratamento e um de comparação, as letras K, L, M e N, na Tabela 5.4, denotam a contagem de acidentes que corresponde aos títulos das linhas e das colunas. Os valores 
esperados destas contagens de acidente são indicados pelas correspondentes letras gregas $\kappa, \lambda, \mu e v$.

Tabela 5. 4 - Contagens de acidentes e valores esperados

\begin{tabular}{ccc} 
& Grupo de Tratamento & Grupo de Comparação \\
\hline Antes & $\mathrm{K}, \kappa$ & $\mathrm{M}, \mu$ \\
\hline Depois & $\mathrm{L}, \lambda$ & $\mathrm{N}, \nu$ \\
\hline
\end{tabular}

O método utilizando Grupo de Comparação, ou método G-C, é baseado na perspectiva de que na ausência de tratamento, a razão entre o número esperado de acidentes "antes" e "depois" seria a mesma nos grupos de tratamento e de comparação. Assim, define-se:

$r_{\mathrm{c}}=v / \mu$

sendo:

$r_{c}$ : razão das contagens esperadas de acidente para o grupo de comparação. $\mathrm{r}_{\mathrm{T}}=\pi / \kappa$

sendo:

$\mathrm{r}_{\mathrm{T}}$ : razão das contagens esperadas de acidente para o grupo de tratamento. A esperança mencionada acima pode agora ser expressa como uma equação. A esperança é que

$$
r_{\mathrm{T}}=\mathrm{r}_{\mathrm{C}}
$$

ou, equivalente a 
$r_{C} / r_{T}=1$

Da definição de $\mathrm{r}_{\mathrm{T}}$, segue que

$\pi=r_{T} . \kappa$

Contudo, se a suposição na Equação 5.9 é verdadeira, então é verdade também que $\pi=r_{C} K$

Uma vez que a $r_{C}$ pode ser estimada a partir do número de acidentes no grupo de comparação ( $\mathrm{M}$ e N na Tabela 5.4), e к pode ser estimado pelo número de acidentes no grupo de tratamento no período "antes" (K), então m pode ser estimado.

Assim como o método Ingênuo é baseado em uma suposição, o mesmo acontece com o método G-C. Da mesma forma que o pressuposto implícito no método Ingênuo nunca será exatamente verdadeiro, assim é a suposição básica do método G-C nunca será totalmente correta. Não se pode argumentar com convicção que, devido a algumas semelhanças externas entre os grupos tratados e de comparação, o pressuposto é "quase certo" ou "provavelmente verdadeiro". O único argumento defensável que se pode formar para justificar o uso de um grupo de comparação em um estudo observacional é empírico ou indutivo. A saber, se alguém pode mostrar que em uma série temporal os valores passados de $r_{T}$ e $r_{C}$ foram suficientemente semelhantes então, ciente das limitações usuais de todos os argumentos indutivos, pode-se supor que as similaridades passadas também acontecem para aquele valor específico de rc que é usado em um específico "estudo G-C". Contudo, se este é o argumento sobre o qual repousa o método $\mathrm{G}-\mathrm{C}$, deve-se permitir na análise a 
possibilidade de que o pressuposto de $r_{T} / r_{C}=1$ não é exatamente verdadeiro em qualquer "estudo G-C" específico. É necessário, portanto considerar que a razão $r_{C} / r_{T}$ seja uma variável aleatória a qual em diferentes ocasiões toma diferentes valores. Coerentes com a terminologia estatística usual associada à Tabela 5.4, a razão $r_{C} / r_{T}$ será chamada de $\omega$.

$\omega=r_{C} / r_{T}$

Considerando uma longa série temporal de contagens de acidente para um grupo de entidades de tratamento e de comparação, a partir dessas contagens de acidente é possível formar uma série temporal como na Tabela 5.4. As quatro contagens de acidente $\mathrm{K}, \mathrm{L}, \mathrm{M}$ e $\mathrm{N}$, em cada tabela são para o mesmo conjunto de entidades, exceto que em nenhum momento o tratamento foi aplicado às entidades para 0 grupo de tratamento. Em cada uma dessas tabelas um valor específico de $\omega$ ocorre. Assim, para cada grupo de entidades de tratamento e de comparação existe uma série temporal de $\omega$. Qualquer seqüência de tal $\omega$ tem uma média $E\{\omega\}$ e uma variância $\operatorname{VAR}\{\omega\}$. Para um grupo de comparação ser considerado legítimo, ele deve atender à exigência de que $E\{\omega\}=1$. Se esta exigência não for cumprida, os últimos $r_{C}$ podem ser sistematicamente maiores ou menores do que o $r_{T}$ correspondente. Isso poderia negar completamente a premissa básica do "estudo G-C". Encontrado o grupo de comparação adequado é possível realizar a análise estatística de um estudo G-C. As estimativas dos parâmetros $\hat{\lambda}, \hat{\pi}$ e $\hat{r}_{\mathrm{t}}$ e de suas variâncias são obtidos através das etapas 1 e 2 listadas na Tabela 5.5 . 
Tabela 5. 5 - Estimativas das ETAPAS 1 e 2 em um "Estudo G-C"

Estimativas dos Parâmetros

ETAPA 1
Estimativas das Variâncias

$$
\text { ETAPA } 2
$$

\begin{tabular}{cc}
\hline$\hat{\lambda}=L$ & $V \hat{\mathrm{A}} R\{\hat{\lambda}\}=L$ \\
\hline$\hat{r}_{T}=\hat{r}_{C}=(N / M) /(1+1 / M) \approx N / M$ & $V \hat{\mathrm{A}} R\left\{\hat{r}_{T}\right\} / r_{T}{ }^{2} \approx 1 / M+1 / N+V \hat{\mathrm{A}} R\{\omega\}$ \\
\hline$\hat{\pi}=\hat{r}_{T} K$ & $\operatorname{VÂ} R\{\hat{\pi}\} \approx \hat{\pi}^{2}\left[1 / K+V \hat{\mathrm{A}} R\left\{\hat{r}_{T}\right\} / r_{t}{ }^{2}\right]$
\end{tabular}

- $\operatorname{VÂR}\{\omega\}$ é estimado 0 devido a falta de um histórico de acidentes mais longo

A Tabela 5.6 indica como calcular as etapas 3 e 4, onde são obtidos os valores de $\delta$ e $\theta$ e suas variáveis.

Tabela 5.6 - ETAPAS 3 e 4.

\begin{tabular}{l}
\hline$\delta=\pi-\lambda$ \\
$\operatorname{VAR}\{\hat{\delta}\}=\operatorname{VAR}\{\hat{\pi}\}+\operatorname{VAR}\{\hat{\lambda}\}$ \\
$\hat{\theta}=(\lambda / \pi) /\left[1+\operatorname{VAR}\{\hat{\pi}\} / \pi^{2}\right]$ \\
$\operatorname{VAR}\{\hat{\theta}\} \approx \theta^{2}\left[\left(\operatorname{VAR}\{\hat{\lambda}\} / \lambda^{2}\right)+\left(\operatorname{VAR}\{\hat{\pi}\} / \pi^{2}\right)\right] /\left[1+\left(\operatorname{VAR}\{\hat{\pi}\} / \pi^{2}\right]^{2}\right.$
\end{tabular}

Os valores do desvio padrão para a estimativa dos parâmetros encontrados através das etapas acima é calculado de cardo com a Tabela 5.7:

Tabela 5. 7- Cálculo da estimativo do desvio padrão

Estimativa do desvio Padrão

\begin{tabular}{c|c}
\hline$\hat{\sigma}\{\hat{\lambda}\}$ & $\sqrt{\lambda}$ \\
\hline$\hat{\sigma}\{\hat{\pi}\}$ & $\sqrt{\pi}$ \\
\hline$\hat{\sigma}\{\hat{\delta}\}$ & $\sqrt{ } V A R \hat{\lambda}+V A R \hat{\pi}$ \\
\hline$\hat{\sigma}\{\hat{\theta}\}$ & $\hat{\theta}^{*}\left[\sqrt{ }\left(1 / \hat{\lambda}_{+1 /} \hat{\pi}\right)\right] /(1+1 / \hat{\pi})$ \\
\hline
\end{tabular}




\subsection{Retratações que devem ser feitas na utilização dos estudos observacionais}

Os dois métodos descritos acima não incorporam outros fatores contribuintes para os acidentes de trânsito, tais como: tráfego (fluxo e composição), meteorologia (condições climáticas), frota de veículos, comportamento dos motoristas, custos da reparação de veículos, etc., na análise e, por isso, retratações devem ser feitas ao se apresentar os resultados, de modo a ser tornar evidente que os acidentes podem ser resultados de outras ações e outros fatores e não devida unicamente ao tratamento (intervenção) realizado na via.

Por essa razão, Hauer (1997) propõe duas retratações quando se apresentam os resultados desse tipo de estudo e que são descritas a seguir.

\section{Retratação N. ${ }^{\circ} 1$}

"A mudança notada na segurança reflete não apenas o efeito de ... (nome do tratamento), mas também o efeito de fatores como o tráfego, meteorologia (tempo), frota de veículos, comportamento motorista, custo da reparação de automóveis, etc. Não se sabe que parte da mudança pode ser atribuída a ... (nome do tratamento) e que parte se deve às várias outras influências."

Se existe a mais leve suspeita de que a decisão de tratar as entidades foi influenciada por seu registro de acidentes passado, bom ou mau, e que o mesmo registro de acidentes passado foi utilizado como parte dos dados de "antes", deve-se acrescentar:

\section{Retratação N. ${ }^{\circ} 2$}

"A mudança notada em segurança pode ser, em parte, devido à regressão espontânea para a média e não devido a ... (nome do tratamento)." 


\section{AVALIAÇÃ DA CAPACIDADE}

\subsection{Considerações iniciais}

Para a pesquisa de campo as seguintes condições foram observadas:

- interseções praticamente planas, ou seja, sem declividade,

- estudou-se apenas uma faixa de tráfego por interseção, na qual foi observada as seguintes características: faixas largas, onde o fluxo fluía livremente sem interrupções e interferências como manobras de estacionamento e/ou outras situações que modificassem a fluidez do trânsito,

- faixa constituída apenas de tráfego de automóveis

- faixa em que os veículos seguiam em frente, ou seja, sem conversões.

Foram coletados dados de três semáforos com grupo focal convencional e três semáforos com grupo focal com indicação do tempo de verde/vermelho restante, em cada uma das três cidades pesquisadas, abrangendo 30 ciclos de cada semáforo. A pesquisa foi realizada no mês de setembro de $2010 \mathrm{em}$ ambas as cidades, todas realizadas no período de pico da tarde (17:00 às 18:00 horas).

A duração do tempo amarelo, do vermelho total e do ciclo empregado nos semáforos analisados nas três cidades estudadas são os seguintes: 
- São Carlos: amarelo $=3 \mathrm{~s}$, vermelho total $=2 \mathrm{~s}$ e ciclo $=80 \mathrm{~s}$.

- Ribeirão Preto: amarelo $=3 \mathrm{~s}$, vermelho total $=0$ (não é utilizado) e ciclo $=$ 60 s.

- Piracicaba: amarelo $=4 \mathrm{~s}$, vermelho total $=2 \mathrm{~s}$ e ciclo $=100 \mathrm{~s}$.

\subsection{Resultados obtidos}

Os resultados obtidos nas pesquisas de campo para os parâmetros que afetam a capacidade semafórica são apresentados nas Tabelas 6.1, 6.2 e 6.3 para as cidades de São Carlos, Ribeirão Preto e Piracicaba, respectivamente. As variáveis apresentadas nas Tabelas seguintes são: h: headway (segundos), Tpi: Tempo perdido no início (segundos); Tpf: Tempo perdido no final (segundos); Tpt: tempo perdido total (segundos). 
Tabela 6. 1- Resultados obtidos na cidade de São Carlos

\begin{tabular}{|c|c|c|c|c|c|c|c|c|}
\hline \multirow{2}{*}{$\begin{array}{l}\text { Tipo de Grupo } \\
\text { Focal }\end{array}$} & \multirow{2}{*}{ Via } & \multicolumn{4}{|c|}{ Média } & \multicolumn{3}{|c|}{ Desvio Padrão } \\
\hline & & $\mathrm{h}$ & Tpi & Tpf & Tpt & $\mathrm{h}$ & Tpi & Tpf \\
\hline \multirow{4}{*}{ Comum } & $\begin{array}{l}\text { Padre Teixeira X } \\
\text { Av. São Carlos }\end{array}$ & 2,35 & 2,83 & 2,10 & 4,93 & 0,01 & 0,55 & 0,39 \\
\hline & $\begin{array}{l}\text { Carlos Botelho X } \\
\text { Av. São Carlos }\end{array}$ & 2,07 & 3,41 & 2,07 & 5,48 & 0,26 & 0,54 & 0,43 \\
\hline & $\begin{array}{l}15 \text { de novembro } \\
\text { X Av. São Carlos }\end{array}$ & 2,13 & 3,02 & 2,04 & 5,06 & 0,14 & 0,66 & 0,27 \\
\hline & GLOBAL & 2,18 & 3,09 & 2,07 & 5,16 & - & - & - \\
\hline \multirow{4}{*}{ Informador } & $\begin{array}{l}\text { São Carlos X } \\
\text { Padre Teixeira }\end{array}$ & 2,34 & 2,49 & 1,92 & 4,41 & 0,45 & 0,55 & 0,41 \\
\hline & $\begin{array}{l}\text { São Carlos X } \\
\text { Carlos Botelho }\end{array}$ & 2,21 & 2,8 & 1,88 & 4,68 & 0,19 & 0,67 & 0,46 \\
\hline & $\begin{array}{l}\text { São Carlos X } 15 \\
\text { de Novembro }\end{array}$ & 2,15 & 2,86 & 1,84 & 4,70 & 0,24 & 0,57 & 0,31 \\
\hline & GLOBAL & 2,23 & 2,72 & 1,88 & 4,60 & - & - & - \\
\hline \multicolumn{2}{|c|}{$\begin{array}{c}\text { Diferença absoluta } \\
\text { (informador - comum) }\end{array}$} & 0,05 & $-0,37$ & $-0,19$ & $-0,56$ & - & - & - \\
\hline \multicolumn{2}{|c|}{ Diferença relativa (\%) } & 2,29 & $-11,97$ & $-9,18$ & $-10,85$ & - & - & - \\
\hline
\end{tabular}


Tabela 6. 2 - Resultados obtidos na cidade de Ribeirão Preto

\begin{tabular}{|c|c|c|c|c|c|c|c|c|}
\hline \multirow{2}{*}{$\begin{array}{c}\text { Tipo de Grupo } \\
\text { Focal }\end{array}$} & \multirow{2}{*}{ Via } & \multicolumn{4}{|c|}{ Média } & \multicolumn{3}{|c|}{ Desvio Padrão } \\
\hline & & $\mathrm{h}$ & Tpi & Tpf & Tpt & $\mathrm{h}$ & Tpi & Tpf \\
\hline \multirow{4}{*}{ Comum } & $\begin{array}{l}\text { São Sebastião X } \\
\text { Jerônimo Gonçalves }\end{array}$ & 2,04 & 3,33 & 0,98 & 4,31 & 0,38 & 0,60 & 0,49 \\
\hline & $\begin{array}{l}\text { José Bonifácio X } \\
\text { Campos Salles }\end{array}$ & 2,10 & 2,95 & 1,03 & 3,98 & 0,25 & 0,77 & 0,31 \\
\hline & $\begin{array}{l}\text { São Sebastião X } \\
\text { José Bonifácio }\end{array}$ & 2,17 & 3,70 & 1,07 & 4,77 & 0,22 & 0,71 & 0,52 \\
\hline & GLOBAL & 2,10 & 3,33 & 1,03 & 4,35 & - & - & - \\
\hline \multirow{4}{*}{ Informador } & $\begin{array}{l}\text { José Bonifácio X } \\
\text { Campos Salles }\end{array}$ & 2,18 & 3,33 & 0,93 & 4,26 & 0,36 & 0,84 & 0,33 \\
\hline & $\begin{array}{c}\text { José Bonifácio X } \\
\text { Prudente de Moraes }\end{array}$ & 2,13 & 3,06 & 0,97 & 4,03 & 0,49 & 0,65 & 0,29 \\
\hline & $\begin{array}{l}\text { José Bonifácio X } \\
\text { Rui Barbosa }\end{array}$ & 2,23 & 2,42 & 0,98 & 3,40 & 0,33 & 0,22 & 0,58 \\
\hline & GLOBAL & 2,18 & 2,94 & 0,96 & 3,90 & - & - & - \\
\hline \multicolumn{2}{|c|}{$\begin{array}{l}\text { Diferença absoluta } \\
\text { (informador - comum) }\end{array}$} & 0,08 & $-0,39$ & $-0,07$ & $-0,45$ & - & - & - \\
\hline \multicolumn{2}{|c|}{ Diferença relativa (\%) } & 3,81 & $-11,71$ & $-6,80$ & $-10,34$ & - & - & - \\
\hline
\end{tabular}


Tabela 6. 3 - Resultados obtidos na cidade de Piracicaba

\begin{tabular}{|c|c|c|c|c|c|c|c|c|}
\hline \multirow{2}{*}{$\begin{array}{l}\text { Tipo de } \\
\text { Grupo Focal }\end{array}$} & \multirow{2}{*}{ Via } & \multicolumn{4}{|c|}{ Média } & \multicolumn{3}{|c|}{ Desvio Padrão } \\
\hline & & $\mathrm{h}$ & Tpi & Tpf & Tpt & $\mathrm{h}$ & Tpi & Tpf \\
\hline \multirow{4}{*}{ Comum } & $\begin{array}{l}\text { Armando Salles X } \\
15 \text { de Novembro }\end{array}$ & 1,95 & 3,08 & 3,25 & 6,33 & 0,16 & 0,58 & 0,53 \\
\hline & $\begin{array}{l}\text { Armando Salles X } \\
15 \text { de Novembro* }\end{array}$ & 2,04 & 3,00 & 2,68 & 5,68 & 0,34 & 0,11 & 0,58 \\
\hline & $\begin{array}{l}\text { Armando Salles X } \\
\text { Regente Feijó }\end{array}$ & 2,32 & 3,16 & 3,08 & 6,24 & 0,24 & 0,21 & 0,65 \\
\hline & GLOBAL & 2,10 & 3,08 & 3,00 & 6,08 & - & - & - \\
\hline \multirow{4}{*}{ Informador } & $\begin{array}{l}15 \text { de Novembro } X \\
\text { Armando Salles }\end{array}$ & 2,06 & 3,08 & 3,15 & 6,23 & 0,10 & 0,44 & 0,60 \\
\hline & $\begin{array}{l}\text { Armando Salles X } \\
\text { Dom Pedro I }\end{array}$ & 2,16 & 3,16 & 2,68 & 5,84 & 0,32 & 0,43 & 0,32 \\
\hline & $\begin{array}{l}\text { José Micheletti X } \\
\text { Dom Pedro I }\end{array}$ & 2,26 & 2,69 & 2,92 & 5,61 & 0,31 & 0,64 & 0,40 \\
\hline & GLOBAL & 2,16 & 2,98 & 2,92 & 5,90 & - & - & - \\
\hline \multicolumn{2}{|c|}{$\begin{array}{l}\text { Diferença absoluta } \\
\text { (informador - comum) }\end{array}$} & 0,06 & $-0,10$ & $-0,08$ & $-0,18$ & - & - & - \\
\hline \multicolumn{2}{|c|}{ Diferença relativa (\%) } & 2,86 & $-3,25$ & $-2,67$ & $-2,96$ & - & - & - \\
\hline
\end{tabular}

Na Tabela 6.4 estão assinalados os resultados obtidos para a capacidade horária de interseções semafóricas localizadas nas três cidades, considerando os valores dos parâmetros obtidos nas pesquisas e as seguintes hipóteses: cruzamento comum de 2 vias de sentido único com 1 faixa de tráfego cada uma, todas as faixas com o mesmo desempenho operacional, semáforo de 2 fases e tempo de ciclo $=80$ segundos para a cidade de São Carlos, 60 segundos para a cidade de Ribeirão Preto e 100 segundos para a cidade de Piracicaba (valores praticados nos semáforos pesquisados nessas cidades). 
Tabela 6. 4 - Resultados obtidos para a capacidade horária

\begin{tabular}{|c|c|c|c|c|c|c|}
\hline \multirow[b]{2}{*}{ Parâmetro } & \multicolumn{2}{|c|}{ São Carlos } & \multicolumn{2}{|c|}{ Ribeirão Preto } & \multicolumn{2}{|c|}{ Piracicaba } \\
\hline & $\begin{array}{l}\text { Grupo } \\
\text { Focal } \\
\text { Comum }\end{array}$ & $\begin{array}{l}\text { Grupo } \\
\text { Focal com } \\
\text { Informador }\end{array}$ & $\begin{array}{l}\text { Grupo } \\
\text { Focal } \\
\text { Comum }\end{array}$ & $\begin{array}{l}\text { Grupo } \\
\text { Focal com } \\
\text { Informador }\end{array}$ & $\begin{array}{l}\text { Grupo } \\
\text { Focal } \\
\text { Comum }\end{array}$ & $\begin{array}{c}\text { Grupo } \\
\text { Focal com } \\
\text { Informador }\end{array}$ \\
\hline Ciclo (s) & 80 & 80 & 60 & 60 & 100 & 100 \\
\hline Quantidade de fases & 2 & 2 & 2 & 2 & 2 & 2 \\
\hline Headway (s) & 2,18 & 2,23 & 2,10 & 2,18 & 2,10 & 2,16 \\
\hline Tempo perdido (s) & 5,16 & 4,60 & 4,35 & 3,90 & 6,08 & 5,90 \\
\hline Tempo perdido no ciclo(s) & 10,32 & 9,20 & 8,70 & 7,80 & 12,16 & 11,80 \\
\hline Capacidade (veíc/h) & 1438 & 1429 & 1466 & 1437 & 1506 & 1470 \\
\hline $\begin{array}{l}\text { Diferença absoluta }(\mathrm{v} / \mathrm{h}) \\
\text { (informador - comum) }\end{array}$ & \multicolumn{2}{|r|}{-9} & \multicolumn{2}{|r|}{-29} & \multicolumn{2}{|c|}{-36} \\
\hline Diferença relativa (\%) & \multicolumn{2}{|c|}{$-0,63$} & \multicolumn{2}{|c|}{$-1,64$} & \multicolumn{2}{|c|}{$-2,39$} \\
\hline $\begin{array}{l}\text { Capacidade supondo não } \\
\text { alteração do headway } \\
\text { (veíc/h) }\end{array}$ & 1438 & 1461 & 1466 & 1491 & 1506 & 1512 \\
\hline $\begin{array}{l}\text { Diferença absoluta }(\mathrm{v} / \mathrm{h}) \\
\text { (informador - comum) }\end{array}$ & \multicolumn{2}{|r|}{23} & \multicolumn{2}{|r|}{25} & \multicolumn{2}{|r|}{6} \\
\hline Diferença relativa (\%) & \multicolumn{2}{|r|}{1,60} & \multicolumn{2}{|r|}{1,71} & \multicolumn{2}{|c|}{0,40} \\
\hline
\end{tabular}

\subsection{Análise dos resultados obtidos}

Com base nos resultados obtidos, as principais conclusões quando se compara o desempenho operacional dos semáforos com grupo focal com informador de tempo em relação aqueles com grupo focal comum são as seguintes:

- Em todas as cidades, o valor do headway em grupo focal com informador de tempo é ligeiramente maior do que em grupo focal comum: São Carlos $=0,05$ $(2,29 \%)$, Ribeirão Preto $=0,08(3,81 \%)$ e Piracicaba $=0,06(2,86 \%)$. Não se tem explicação para tal fato. A Figura 6.1 ilustra a variação dos headway obtidos. 
$\square$ Grupo focal comum

Grupo focal com ITR

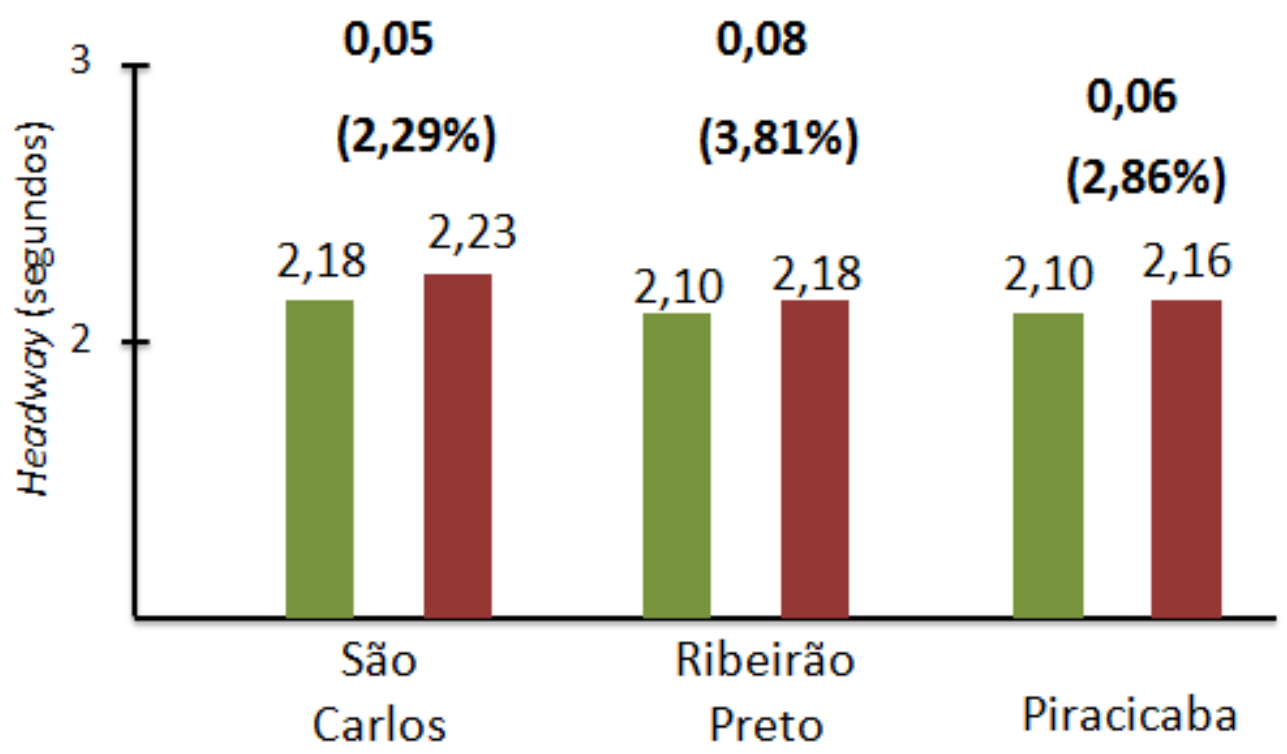

Cidades analisadas

Figura 6. 1 - Variação dos Headway obtidos

- Em todas as cidades, o valor do tempo perdido no início em grupo focal com informador de tempo é ligeiramente menor do que em grupo focal comum: São Carlos $=-0,37(-11,97 \%)$, Ribeirão Preto $=-0,39(-11,71 \%)$ e Piracicaba $=$ $-0,10(-3,25 \%)$. Explicação provável: o aviso da mudança do vermelho para o verde faz com que os condutores fiquem mais atentos e partam mais rapidamente. A Figura 6.2 ilustra a variação do tempo inicial perdido nas cidades analisadas. 


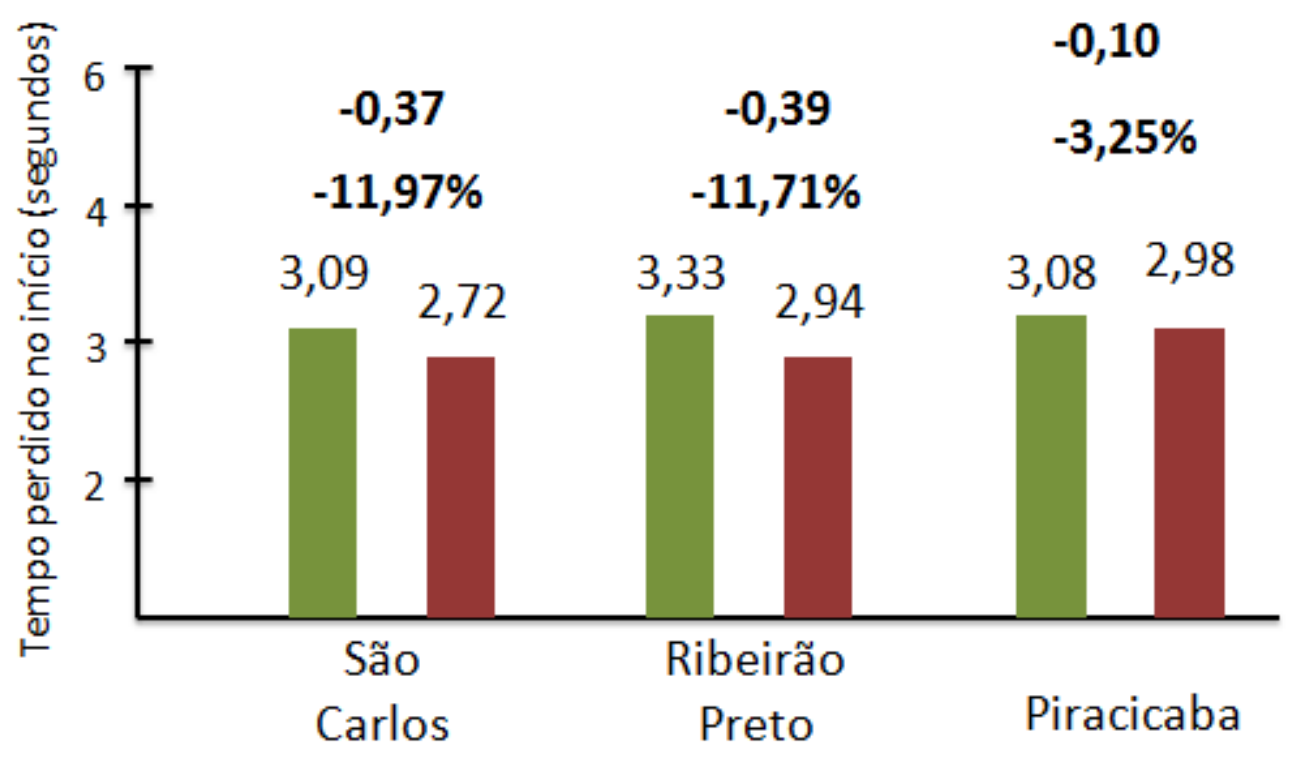

Cidades analisadas

Figura 6. 2 - Variação do Tempo perdido no início

- Em todas as cidades, o valor do tempo perdido no final em grupo focal com informador de tempo é ligeiramente menor do que em grupo focal comum: São Carlos $=-0,19(-9,18 \%)$, Ribeirão Preto $=-0,07(-6,80 \%)$ e Piracicaba $=-$ $0,08(-2,67 \%)$. Explicação provável: o aviso de que o tempo verde está terminando faz com que os condutores forcem a passagem para aproveitar 0 final da luz verde. A Figura 6.3 ilustra a variação do tempo perdido no final nas cidades analisadas. 
Cidades analisadas

Figura 6. 3 - Variação do tempo perdido no início

- Em todas as cidades, o valor do tempo perdido total em grupo focal com informador de tempo é ligeiramente menor do que em grupo focal comum: São Carlos $=-0,56(-10,85 \%)$, Ribeirão Preto $=-0,45(-10,34 \%)$ e Piracicaba $=$ $-0,18(-2,96 \%)$. Explicação provável: a associação das duas explicações anteriormente colocadas. A Figura 6.4 ilustra a variação do tempo perdido total nas cidades analisadas. 


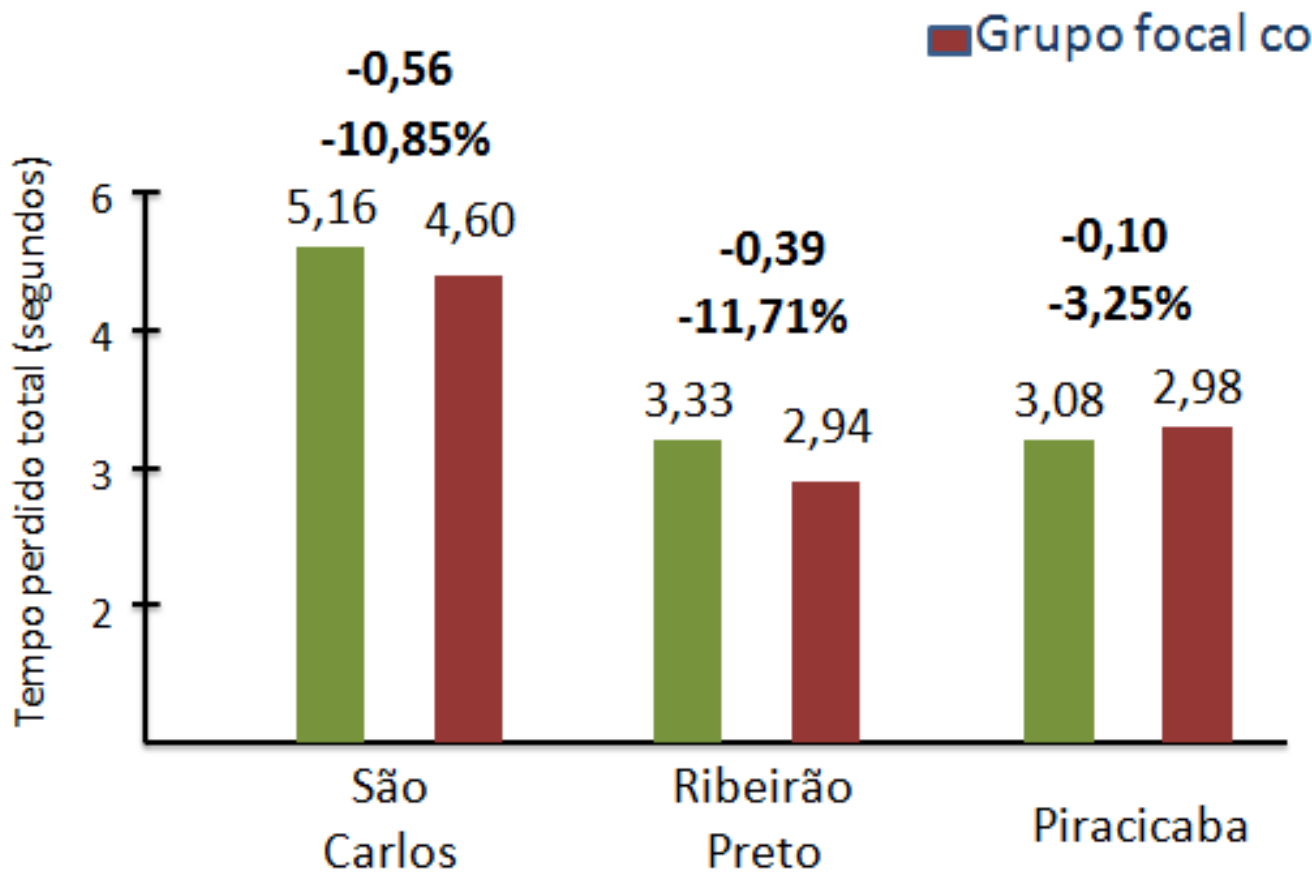

Cidades analisadas

Figura 6. 4 - Variação do tempo perdido total

- Em todas as cidades, o valor da capacidade em grupo focal com informador de tempo é ligeiramente menor do que em grupo focal comum: São Carlos = 9v/h $(-0,63 \%)$, Ribeirão Preto $=-29 v / h(-1,64 \%)$ e Piracicaba $=-36 v / h(-$ 2,39\%). Explicação provável: o pequeno aumento no valor do headway tem maior impacto sobre a capacidade do que a pequena redução no valor do tempo total perdido. 


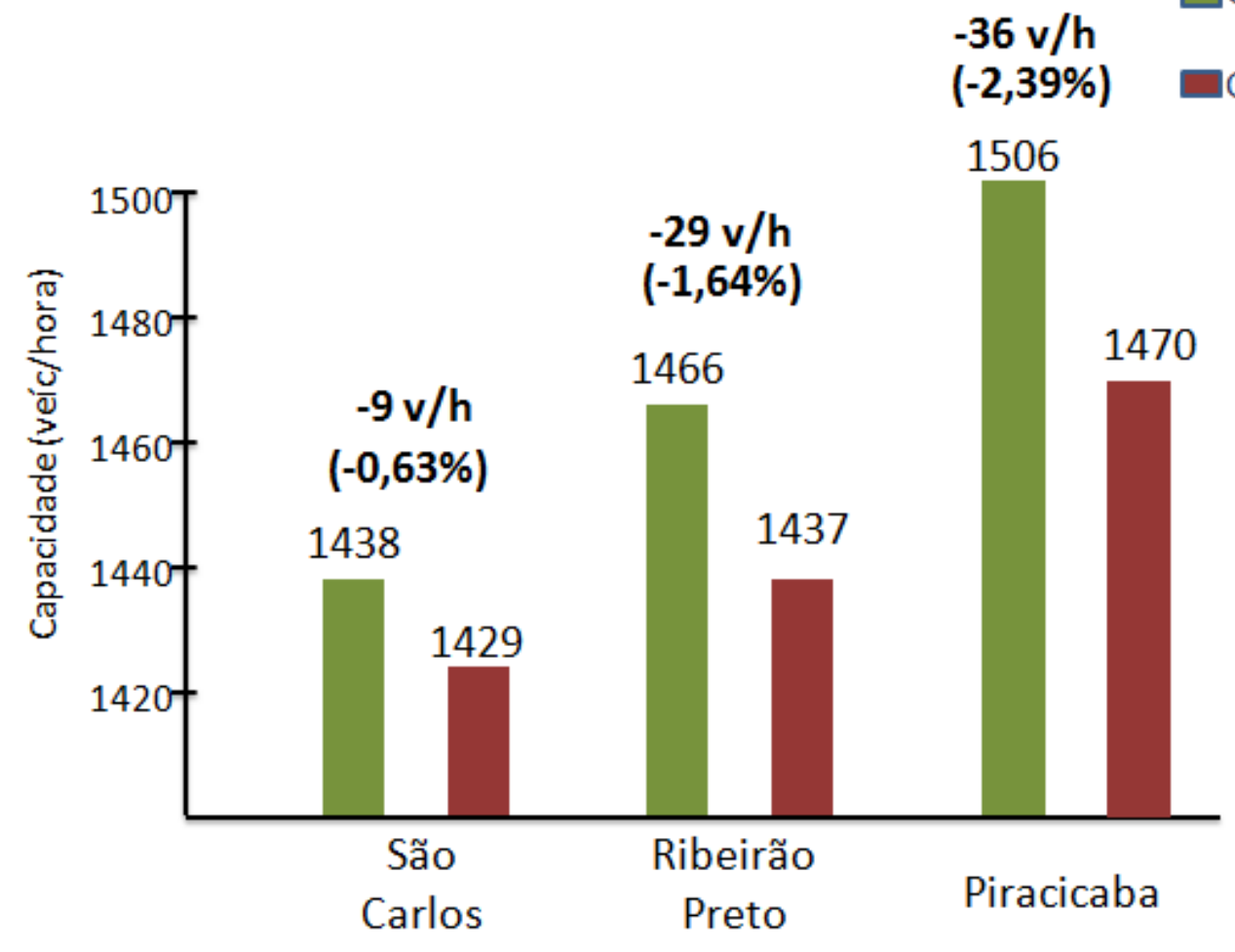

Cidades analisadas

Figura 6. 5 - Variação da Capacidade

- Em todas as cidades, admitindo que não haja alteração no valor do headway relativo ao grupo focal comum, a capacidade em grupo focal com informador de tempo é ligeiramente maior do que em grupo focal comum: São Carlos = 23v/h (1,60\%), Ribeirão Preto $=25 \mathrm{v} / \mathrm{h}(1,71 \%)$ e Piracicaba $=6 \mathrm{v} / \mathrm{h}(0,40 \%) . A$ Figura 6.6 ilustra a variação da capacidade supondo não haver variação do headway. 


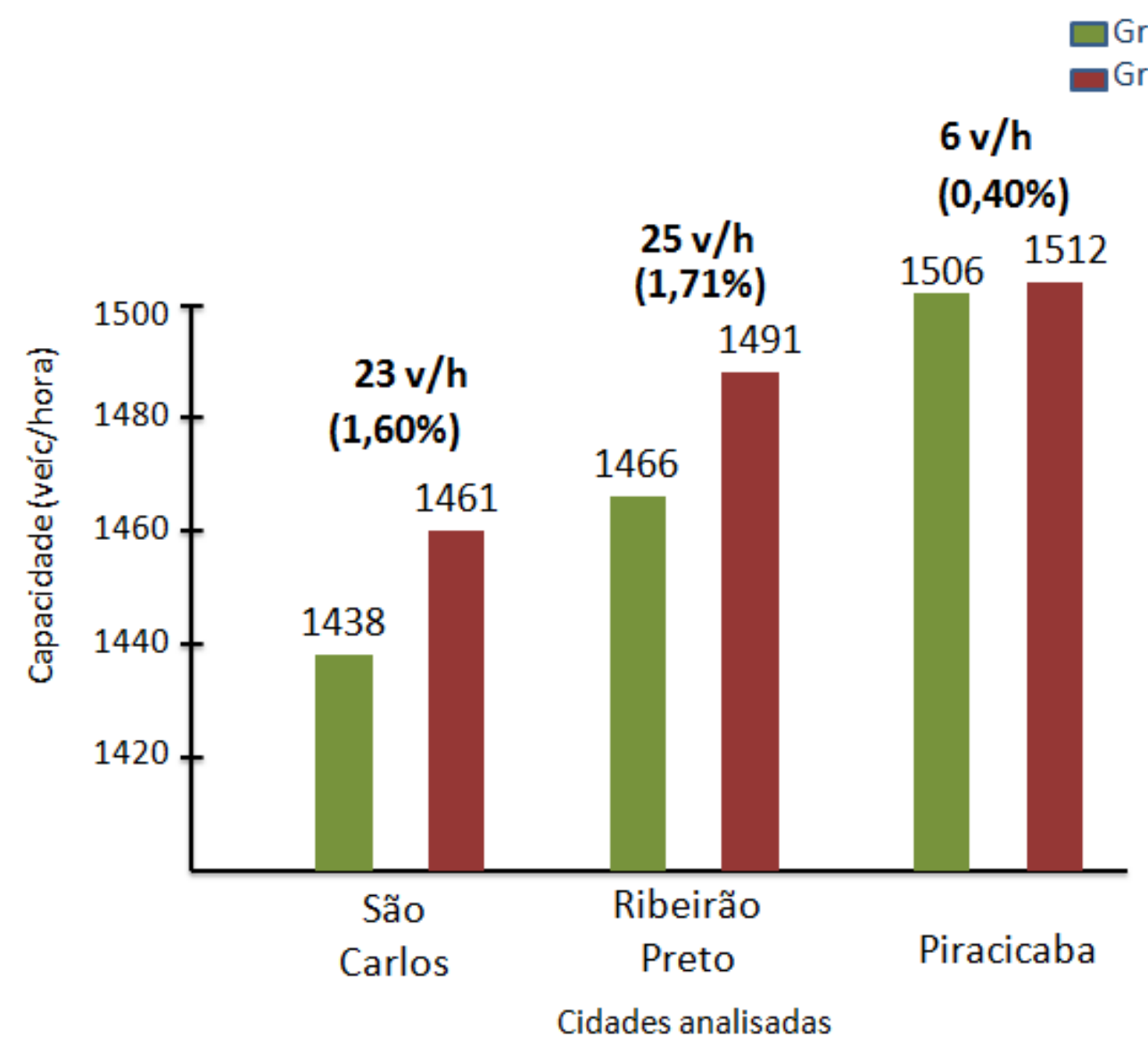

Figura 6. 6 - Variação da Capacidade supondo não haver variação do headway

À luz dos resultados obtidos, pode-se dizer que não há diferença significativa no desempenho operacional de semáforos com grupo focal dotado de informador de tempo (qualquer que seja o modelo) em relação a semáforos com grupo focal comum. Mais explicitamente: não há, praticamente, alteração no valor da capacidade da passagem de veículos pela interseção semaforizada quando se substitui grupo focal comum por grupo focal com informador de tempo. 


\section{AVALIAÇÃ DA SEGURANÇA}

\subsection{Considerações iniciais}

As fontes de dados de acidentes utilizadas foram as seguintes:

- Na cidade de São Carlos: banco de dados da Prefeitura Municipal processado pela Universidade Federal de São Carlos (UFSCAR)

- Na cidade de Ribeirão Preto: banco de dados cedido pela TRANSERP (Empresa de Transporte Urbano de Ribeirão Preto S/A)

- Na cidade de Piracicaba: banco de dados da Prefeitura Municipal

Todos os bancos de dados citados são elaborados com base nos boletins de ocorrência da Policia Militar do Estado de São Paulo.

Foram aplicados dois métodos distintos na análise da segurança viária (acidentalidade no trânsito):

- Método 1 - Comparação do desempenho antes e depois da colocação do grupo focal com informador de tempo na via principal em substituição a grupo focal comum, considerando um grupo de seis semáforos em São Carlos, e sete semáforos em Ribeirão Preto e Piracicaba. 
- Método 2 - Comparação do desempenho dos mesmos grupos de semáforos dotados de grupo focal com informador de tempo considerados no estudo anterior com o desempenho de um grupo de semáforos dotados de grupo focal convencional com características semelhantes, sendo quatro em São Carlos e cinco em Ribeirão Preto. Esse estudo não foi realizado na cidade de Piracicaba por não se ter obtido em tempo hábil as informações necessárias.

Em nenhuma das cidades estudadas, havia semáforos em que tivesse ocorrida a troca de todos os grupos focais comuns por grupos focais com informador de tempo; a mudança foi realizada apenas na via principal, permanecendo a via secundária com grupo focal comum. Dessa forma, os resultados obtidos nas comparações do desempenho com relação à acidentalidade dizem respeito apenas às interseções que operam com grupo focal com informador de tempo na via principal e grupo focal comum na via secundária.

\subsection{Método 1: Estudo antes - depois ingênuo}

\section{São Carlos}

Foram analisadas seis interseções, nas quais os grupos focais comuns da via principal foram substituídos por grupos focais com informador de tempo em outubro de 2006. Por constituir um período de adaptação, os acidentes relativos ao mês de outubro de 2006 não foram considerados no estudo.

Na Tabela 7.1 está relacionado o número de acidentes relativos aos períodos de um ano antes e um ano depois da mudança dos grupos focais. 
Tabela 7. 1- Número de acidentes no ano anterior e posterior à mudança em São Carlos

\begin{tabular}{|c|c|c|c|c|c|}
\hline Interseção (j) & $\begin{array}{c}\text { Número de } \\
\text { acidentes no ano } \\
\text { anterior } \\
\mathrm{K}(\mathrm{j})\end{array}$ & $\begin{array}{c}\text { Número de } \\
\text { acidentes no ano } \\
\text { posterior } \\
\text { L(j) }\end{array}$ & $\begin{array}{l}\text { Período de } \\
\text { tempo em } \\
\text { anos } \\
\text { rd(j) }\end{array}$ & $\begin{array}{c}\text { Fator } \\
\operatorname{rd}(\mathrm{j}) \mathrm{K}(\mathrm{j})\end{array}$ & $\begin{array}{c}\text { Fator } \\
r^{2}(j) K(j)\end{array}$ \\
\hline $\begin{array}{c}1 . \\
\text { São Carlos X } \\
\text { Major José } \\
\text { Inácio }\end{array}$ & 6 & 2 & 1 & 6 & 6 \\
\hline $\begin{array}{c}2 . \\
\text { São Carlos X } \\
\text { Geminiano } \\
\text { Costa }\end{array}$ & 5 & 8 & 1 & 5 & 5 \\
\hline $\begin{array}{c}3 . \\
\text { São Carlos X } \\
\text { Conde do } \\
\text { Pinhal }\end{array}$ & 8 & 9 & 1 & 8 & 8 \\
\hline $\begin{array}{c}4 . \\
\text { São Carlos X } 7 \\
\text { de Setembro }\end{array}$ & 8 & 2 & 1 & 8 & 8 \\
\hline $\begin{array}{c}5 . \\
\text { São Carlos X } \\
15 \text { de } \\
\text { Novembro }\end{array}$ & 16 & 5 & 1 & 16 & 16 \\
\hline $\begin{array}{c}6 . \\
\text { São Carlos X } \\
\text { Carlos Botelho }\end{array}$ & 12 & 11 & 1 & 12 & 12 \\
\hline Total & 55 & 37 & - & 55 & 55 \\
\hline
\end{tabular}


A Tabela 7.2 mostra os resultados obtidos na aplicação do método de análise descrito no capítulo 5.

\begin{tabular}{|c|c|}
\hline$\hat{\lambda}$ & 37 \\
\hline$\hat{\pi}$ & 55 \\
\hline VÂR $\{\hat{\lambda}\}$ & 37 \\
\hline $\mathrm{VÂ} R\{\hat{\pi}\}$ & 55 \\
\hline$\hat{\delta}$ & 18 \\
\hline $\mathrm{VÂ} R\{\hat{\delta}\}$ & 92 \\
\hline$\hat{\theta}$ & 0,66 \\
\hline VÂR $\{\hat{\theta}\}$ & 0,019 \\
\hline$\hat{\sigma}\{\hat{\lambda}\}$ & 6,08 \\
\hline$\hat{\sigma}\{\hat{\pi}\}$ & 7,42 \\
\hline$\hat{\sigma}\{\hat{\delta}\}$ & 9,59 \\
\hline$\hat{\sigma}\{\hat{\theta}\}$ & 0,14 \\
\hline
\end{tabular}

A estimativa, portanto, é que houve uma redução do número total de acidentes nas seis interseções em que houve mudança do grupo focal da via principal de 18 acidentes, com desvio padrão de $\pm 9,59$, ou seja, $34 \%$ na redução de acidentes , com desvio padrão de $\pm 14 \%$.

\section{Ribeirão Preto}

Foram analisadas sete interseções, nas quais os grupos focais comuns da via principal foram substituídos por grupos focais com informador de tempo em 
setembro de 2006. Por constituir um período de adaptação, os acidentes relativos ao mês de setembro de 2006 não foram considerados no estudo.

Na Tabela 7.3 estão relacionados o número de acidentes relativos aos períodos de um 1 ano antes e depois da mudança dos grupos focais.

Tabela 7. 3- Número de acidentes no ano anterior e posterior à mudança em Ribeirão Preto

\begin{tabular}{|c|c|c|c|c|c|}
\hline $\begin{array}{c}\text { Interseção } \\
\text { (j) }\end{array}$ & $\begin{array}{c}\text { Número de } \\
\text { acidentes no } \\
\text { ano anterior } \\
\text { K(j) }\end{array}$ & $\begin{array}{c}\text { Número de } \\
\text { acidentes no } \\
\text { ano posterior } \\
\text { L(j) }\end{array}$ & $\begin{array}{l}\text { Período de } \\
\text { tempo em } \\
\text { anos rd(j) }\end{array}$ & $\begin{array}{c}\text { Fator } \\
\text { rd(j)K(j) }\end{array}$ & $\begin{array}{c}\text { Fator } \\
r^{2}(j) K(j)\end{array}$ \\
\hline $\begin{array}{c}1 . \\
\text { Cerqueira César x } \\
\text { General Osório }\end{array}$ & 0 & 5 & 1 & 0 & 0 \\
\hline $\begin{array}{c}2 . \\
\text { Cerqueira Cesar x } \\
\text { Américo Brasiliense }\end{array}$ & 5 & 1 & 1 & 5 & 5 \\
\hline $\begin{array}{c}3 . \\
\text { Cerqueira Cesar x } \\
\text { Campos Sales }\end{array}$ & 4 & 1 & 1 & 4 & 4 \\
\hline $\begin{array}{c}4 . \\
\text { Saldanha Marinho x } \\
\text { Campos Sales }\end{array}$ & 6 & 4 & 1 & 6 & 6 \\
\hline $\begin{array}{c}5 . \\
\text { Saldanha Marinho x } \\
\text { Florêncio Abreu }\end{array}$ & 3 & 9 & 1 & 3 & 3 \\
\hline $\begin{array}{c}6 . \\
\text { Saldanha Marinho x } \\
\text { Lafaiete }\end{array}$ & 12 & 2 & 1 & 12 & 12 \\
\hline $\begin{array}{c}7 . \\
\text { Amador Bueno x Rui } \\
\text { Barbosa }\end{array}$ & 7 & 14 & 1 & 7 & 7 \\
\hline Total & 37 & 36 & & 37 & 37 \\
\hline
\end{tabular}


A Tabela 7.4 mostra os resultados obtidos na aplicação do método de análise descrito no capítulo 5 .

Tabela 7. 4- Resultados obtidos em Ribeirão
\begin{tabular}{c|c}
$\hat{\lambda}$ & 36 \\
\hline$\hat{\pi}$ & 37 \\
\hline $\operatorname{VÂR}\{\hat{\lambda}\}$ & 36 \\
\hline $\operatorname{VÂ} R\{\hat{\pi}\}$ & 37 \\
\hline$\hat{\delta}$ & 1 \\
\hline $\operatorname{VÂR}\{\hat{\delta}\}$ & 73 \\
\hline$\hat{\theta}$ & 0,95 \\
\hline $\operatorname{VÂ} R\{\hat{\theta}\}$ & 0,047 \\
\hline$\hat{\sigma}\{\hat{\lambda}\}$ & 6 \\
\hline$\hat{\sigma}\{\hat{\pi}\}$ & 6,1 \\
\hline$\hat{\sigma}\{\hat{\delta}\}$ & 8,54 \\
\hline$\hat{\sigma}\{\hat{\theta}\}$ & 0,22 \\
\hline
\end{tabular}

A estimativa, portanto, é que houve uma redução do número total de acidentes nas sete interseções em que houve mudança do grupo focal da via principal de 1 acidente, com desvio padrão de $\pm 8,50$, ou seja, uma redução no nemero de acidentes de $5 \%$ com desvio padrão de $\pm 22 \%$.

\section{Piracicaba}

Foram analisadas seis interseções, nas quais os grupos focais comuns da via principal foram substituídos por grupos focais com informador de tempo na via principal entre janeiro e setembro de 2008. 
Na Tabela 7.5 estão relacionados o número de acidentes relativos aos períodos de um ano antes e um ano depois da mudança dos grupos focais, não considerando o mês da substituição.

Tabela 7. 5- Número de acidentes no ano anterior e posterior à mudança em Piracicaba

\begin{tabular}{|c|c|c|c|c|c|}
\hline $\begin{array}{c}\text { Interseção } \\
\text { (j) }\end{array}$ & $\begin{array}{c}\text { Número de } \\
\text { acidentes no ano } \\
\text { anterior } \\
\mathrm{K}(\mathrm{j})\end{array}$ & $\begin{array}{l}\text { Número de } \\
\text { acidentes no } \\
\text { ano posterior } \\
\text { L(j) }\end{array}$ & $\begin{array}{l}\text { Período de } \\
\text { tempo em } \\
\text { anos rd(j) }\end{array}$ & $\begin{array}{l}\text { Fator } \\
\text { rd(j)K(j) }\end{array}$ & $\begin{array}{c}\text { Fator } \\
r^{2}(j) K(j)\end{array}$ \\
\hline $\begin{array}{c}1 . \\
\text { Av.Armando Salles X } \\
\text { Rua Rangel Pestana }\end{array}$ & 1 & 0 & 1 & 1 & 1 \\
\hline $\begin{array}{c}2 . \\
\text { Av.Jaime Pereira X } \\
\text { Av.Dr.Paulo de } \\
\text { Moraes }\end{array}$ & 6 & 2 & 1 & 6 & 6 \\
\hline $\begin{array}{c}3 . \\
\text { Av.Limeira X } \\
\text { Av.Martinho Salgot }\end{array}$ & 7 & 4 & 1 & 7 & 7 \\
\hline $\begin{array}{c}4 . \\
\text { Av.Padua Dias X } \\
\text { Av.Independência }\end{array}$ & 13 & 18 & 1 & 13 & 13 \\
\hline $\begin{array}{c}5 . \\
\text { Av.Rui Barbosa x } \\
\text { Av.Juscelino Kubchet }\end{array}$ & 6 & 2 & 1 & 6 & 6 \\
\hline $\begin{array}{c}6 . \\
\text { Rua do Rosario x } \\
\text { Rua XV de Novembro }\end{array}$ & 6 & 3 & 1 & 6 & 6 \\
\hline $\begin{array}{c}7 . \\
\text { Av.Dr Paulo de } \\
\text { Moraes x Rua do } \\
\text { Rosario }\end{array}$ & 17 & 8 & 1 & 17 & 17 \\
\hline Total & 56 & 37 & & 56 & 56 \\
\hline
\end{tabular}


A Tabela 7.6 mostra os resultados obtidos na aplicação do método de análise descrito no capítulo 5.

Tabela 7. 6- Resultados obtidos em Piracicaba

\begin{tabular}{c|c}
\hline$\hat{\lambda}$ & 37 \\
\hline$\hat{\pi}$ & 56 \\
\hline $\operatorname{VÂR}\{\hat{\lambda}\}$ & 37 \\
\hline $\operatorname{VÂR}\{\hat{\pi}\}$ & 56 \\
\hline$\hat{\delta}$ & 19 \\
\hline $\operatorname{VÂR}\{\hat{\delta}\}$ & 93 \\
\hline$\hat{\theta}$ & 0,65 \\
\hline $\operatorname{VÂR}\{\hat{\theta}\}$ & 0,018 \\
\hline$\hat{\sigma}\{\hat{\lambda}\}$ & 6,08 \\
\hline$\hat{\sigma}\{\hat{\pi}\}$ & 7,48 \\
\hline$\hat{\sigma}\{\hat{\delta}\}$ & 9,64 \\
\hline$\hat{\sigma}\{\hat{\theta}\}$ & 0,14 \\
\hline
\end{tabular}

A estimativa, portanto, é que houve uma redução do número total de acidentes nas sete interseções em que houve mudança do grupo focal da via principal de 19 acidentes com desvio padrão de $\pm 9,64$, ou seja, redução de $35 \%$ no numero de acidentes com desvio padrão de $\pm 14 \%$. 


\subsection{Método 2: Estudo antes - depois utilizando grupo de comparação}

\section{São Carlos}

No estudo observacional antes-depois usando grupo de comparação para a cidade de São Carlos foram selecionadas seis interseções que receberam tratamento (as mesmas utilizadas no estudo antes-depois ingênuo) e quatro interseções com carcterísticas similares que não receberam tratamento (interseções de comparação).

As seis interseções que constituem o grupo tratado - aquelas onde o grupo focal comum foi substituido pelo grupo focal com informador de tempo na via principal estão relacionadas na Tabela 7.7 juntamente com o número de acidentes um ano antes e um ano depois da mudança.

Tabela 7. 7- Número de acidentes em interseções tratadas na cidade de São Carlos

\begin{tabular}{c|c|c}
\hline Grupo de interseções tratadas & $\begin{array}{c}\mathbf{1} \text { ano } \\
\text { antes }\end{array}$ & $\begin{array}{c}\mathbf{1} \text { ano } \\
\text { depois }\end{array}$ \\
\hline São Carlos x Major José Inácio & 6 & 2 \\
\hline São Carlos x Geminiano Costa & 5 & 8 \\
\hline São Carlos x Conde do Pinhal & 8 & 9 \\
\hline São Carlos x 7 de Setembro & 8 & 2 \\
\hline São Carlos x 15 de Novembro & 16 & 5 \\
\hline São Carlos x Carlos Botelho & 12 & 11 \\
\hline Total de acidentes & 55 & 37 \\
\hline
\end{tabular}

As quatro interseções que constituem o grupo não tratado - aquelas que continuam operando com grupo focal comum nas duas vias - estão relacionadas na Tabela 7.8 juntamente com o número de acidentes um ano antes um ano depois. 
Tabela 7. 8- Número de acidentes em Interseções não tratadas na cidade de São Carlos

\begin{tabular}{c|c|c}
\hline Grupo de interseções não tratadas & $\begin{array}{c}\text { 1 ano } \\
\text { antes }\end{array}$ & $\begin{array}{c}\text { 1 ano } \\
\text { depois }\end{array}$ \\
\hline Episcopal $\times$ Carlos Botelho & 8 & 13 \\
\hline Episcopal $\times 15$ de Novembro & 9 & 12 \\
\hline 15 de Novembro $\times 9$ de julho & 4 & 2 \\
\hline Carlos Botelho $\times 9$ de julho & 3 & 1 \\
\hline Total de acidentes & 24 & 28 \\
\hline
\end{tabular}

A Tabela 7.9 mostra os resultados obtidos na aplicação do método de análise descrito no capítulo 5.

Tabela 7. 9- Resultados obtidos em São Carlos

\begin{tabular}{c|c}
\hline$\hat{\lambda}$ & 37 \\
\hline$\hat{r}_{T}=\hat{r}_{C}$ & 1,12 \\
\hline$\hat{\pi}$ & 61,60 \\
\hline$V \hat{A} R\{\hat{\lambda}\}$ & 37 \\
\hline$V \hat{A} R\left\{\hat{r}_{-}\right\} / r_{T}{ }^{2}$ & 0,08 \\
\hline$V \hat{A} R\{\hat{\pi}\}$ & 362,62 \\
\hline$\hat{\delta}$ & 24,60 \\
\hline$\hat{\theta}$ & 0,55 \\
\hline$\hat{\sigma}\{\hat{\delta}\}$ & 20,00 \\
\hline$\hat{\sigma}\{\hat{\theta}\}$ & 0,18 \\
\hline
\end{tabular}


A estimativa, portanto, é que houve uma redução do número total de acidentes nas seis interseções em que houve mudança do grupo focal da via principal de 24,60 acidentes com desvio padrão de \pm 20 , ou seja, uma redução de $45 \%$ acidentes com desvio padrão de $\pm 18 \%$.

\section{$\underline{\text { Ribeirão Preto }}$}

No estudo observacional antes-depois usando grupo de comparação para a cidade de Ribeirão Preto foram selecionadas sete interseções que receberam tratamento (as mesmas utilizadas no estudo antes-depois ingênuo) e quatro interseções com carcterísticas similares que não receberam tratamento (interseções de comparação).

As sete interseções que constituem o grupo tratado - aquelas onde o grupo focal comum foi substituido pelo grupo focal com informador de tempo na via principal estão relacionadas na Tabela 7.10 juntamente com o número de acidentes um ano antes e um ano depois da mudança.

Tabela 7. 10- Número de acidentes em interseções tratadas na cidade de Ribeirão Preto

\begin{tabular}{c|c|c}
\hline Grupo de interseções tratadas & $\begin{array}{c}\text { 1 ano } \\
\text { antes }\end{array}$ & $\begin{array}{c}\text { 1 ano } \\
\text { depois }\end{array}$ \\
\hline Cerqueira César x General Osório & 5 & 1 \\
\hline Cerqueira Cesar x Américo Brasiliense & 4 & 1 \\
\hline Cerqueira Cesar x Campos Sales & 6 & 4 \\
\hline Saldanha Marinho x Campos Sales & 3 & 9 \\
\hline Saldanha Marinho x Florêncio Abreu & 12 & 2 \\
\hline Saldanha Marinho x Lafaiete & 7 & 14 \\
\hline Amador Bueno x Rui Barbosa & 0 & 5 \\
\hline Total de acidentes & 37 & 36
\end{tabular}


As cinco interseções que constituem o grupo não tratado - aquelas que continuam operando com grupo focal comum nas duas vias - estão relacionadas na Tabela 7.11 juntamente com o número de acidentes um ano antes e um ano depois.

Tabela 7. 11- Interseções não tratadas na cidade de Ribeirão Preto

\begin{tabular}{l|c|c}
\hline \multicolumn{1}{c|}{ Grupo de interseções não tratadas } & $\begin{array}{c}\mathbf{1} \text { ano } \\
\text { antes }\end{array}$ & $\begin{array}{c}\mathbf{1} \text { ano } \\
\text { depois }\end{array}$ \\
\hline Amador Bueno x Lafaiete & 8 & 7 \\
\hline Amador Bueno x Campos Sales & 7 & 6 \\
\hline Amador Bueno x São Sebastião & 2 & 5 \\
\hline Amador Bueno x Américo Brasiliense & 4 & 9 \\
\hline Álvares Cabral x Lafaiete & 9 & 6 \\
\hline Total de acidentes & 30 & 33 \\
\hline
\end{tabular}


A Tabela 7.12 mostra os resultados obtidos na aplicação do método de análise descrito no Capítulo 5.

Tabela 7. 12- Resultados obtidos em Ribeirão Preto

\begin{tabular}{|c|c|}
\hline$\hat{\lambda}$ & 36 \\
\hline$\hat{r}_{T}=\hat{r}_{C}$ & 1,06 \\
\hline$\hat{\pi}$ & 39,39 \\
\hline$V \hat{\mathrm{A}} R\{\hat{\lambda}\}$ & 36 \\
\hline$V \hat{A} R\left\{\hat{r}_{-}\right\} / r_{T}^{2}$ & 0,06 \\
\hline$V \hat{\mathrm{A}} R\{\hat{\pi}\}$ & 140,65 \\
\hline$\hat{\delta}$ & 3,39 \\
\hline$\hat{\theta}$ & 0,84 \\
\hline$\hat{\sigma}\{\hat{\delta}\}$ & 13,29 \\
\hline$\hat{\sigma}\{\hat{\theta}\}$ & 0,26 \\
\hline
\end{tabular}

A estimativa, portanto, é que houve uma redução do número total de acidentes nas seis interseções em que houve mudança do grupo focal da via principal de 3,39 acidentes com desvio padrão de $\pm 13,29$ acidentes, ou seja, redução de $16 \%$ acidentes com desvio padrão de $\pm 26 \%$. 


\section{Piracicaba}

O estudo antes-depois utilizando grupo de comparação não foi realizado na cidade de Piracicaba por não se ter obtido em tempo hábil as informações necessárias.

\subsection{Análise dos resultados obtidos}

$\mathrm{Na}$ Tabela 7.13 estão relacionados os resultados obtidos nos dois estudos realizados para as três cidades analisadas. A Figura 7.13 ilustra a variação desses resultados

Tabela 7. 13- Resultados obtidos nos dois estudos realizados.

\begin{tabular}{|c|c|c|c|c|}
\hline \multirow[b]{2}{*}{ Método } & \multirow{2}{*}{ Parâmetro } & \multicolumn{3}{|c|}{ Cidade } \\
\hline & & São Carlos & Ribeirão Preto & Piracicaba \\
\hline \multirow{2}{*}{$\begin{array}{c}1 \\
\text { Antes - depois } \\
\text { ingênuo }\end{array}$} & $\begin{array}{c}\text { Valor estimado } \\
\text { da redução dos } \\
\text { acidentes }\end{array}$ & $\begin{array}{c}18 \\
(34 \%)\end{array}$ & $\begin{array}{c}1 \\
(5 \%)\end{array}$ & $\begin{array}{c}19 \\
(35 \%)\end{array}$ \\
\hline & $\begin{array}{l}\text { Desvio } \\
\text { padrão }\end{array}$ & $\begin{array}{c}9,59 \\
(14 \%)\end{array}$ & $\begin{array}{c}8,50 \\
(22 \%)\end{array}$ & $\begin{array}{c}9,64 \\
(14 \%)\end{array}$ \\
\hline \multirow{2}{*}{$\begin{array}{c}2 \\
\text { Antes - depois } \\
\text { comparação }\end{array}$} & $\begin{array}{c}\text { Valor estimado } \\
\text { da redução dos } \\
\text { acidentes }\end{array}$ & $\begin{array}{l}24,60 \\
(45 \%)\end{array}$ & $\begin{array}{c}3,39 \\
(16 \%)\end{array}$ & - \\
\hline & $\begin{array}{l}\text { Desvio } \\
\text { padrão }\end{array}$ & $\begin{array}{l}19,99 \\
(18 \%)\end{array}$ & $\begin{array}{l}13,29 \\
(26 \%)\end{array}$ & - \\
\hline
\end{tabular}




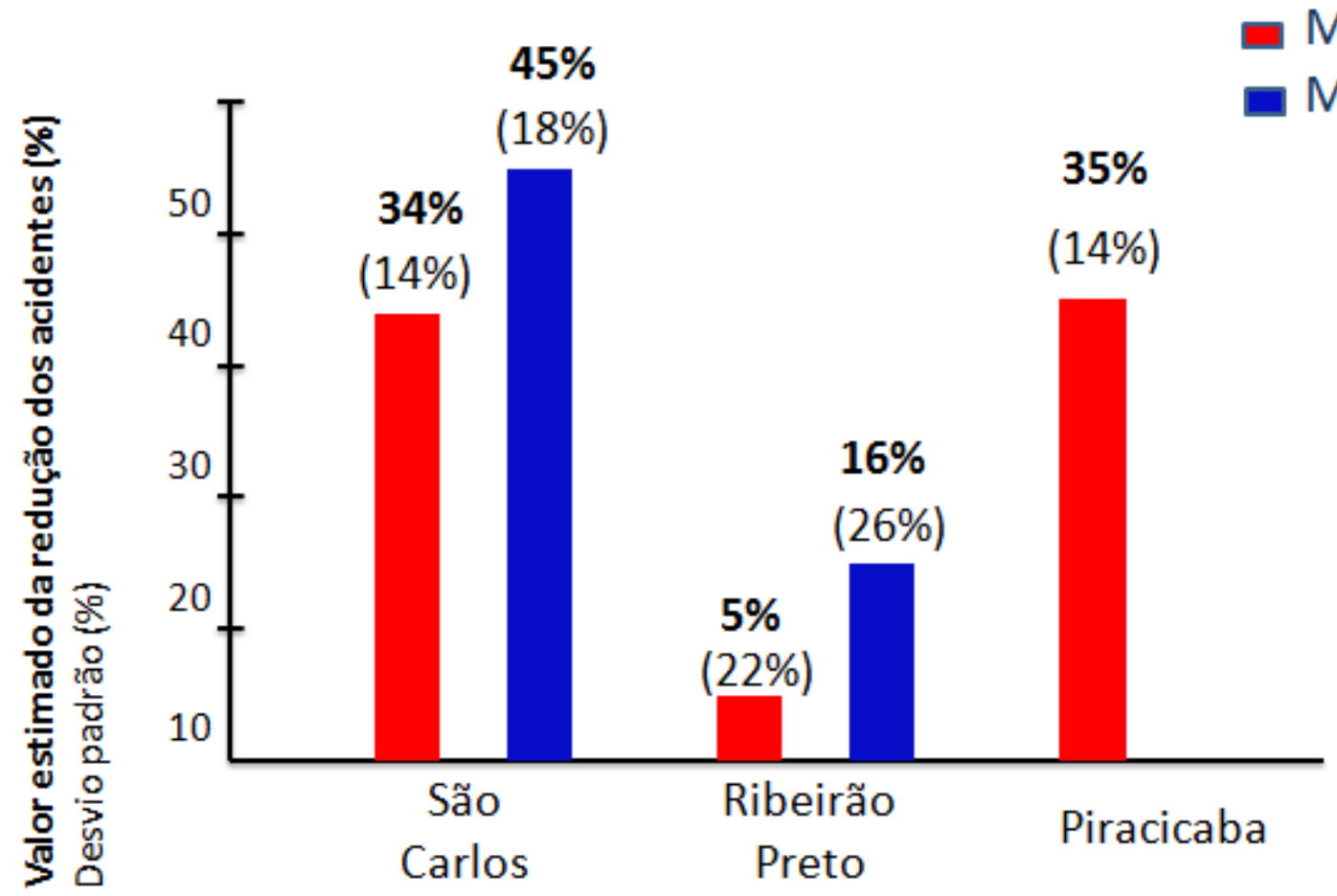

Cidades Analisadas

Figura 7. 1 - Valores estimados da redução dos acidentes

Do ponto de vista estatístico, cabem as seguintes observações com relação aos valores obtidos:

- Os valores estimados para a redução dos acidentes em São Carlos e Ribeirão Preto nos dois métodos mostram-se coerentes, pois estão situados no mesmo patamar: São Carlos (34\% e 45\%), Ribeirão Preto (5\% e 16\%). O estudo 2 não foi realizado em Piracicaba.

- Também nas duas cidades citadas, os valores dos desvios padrão são menores no caso do método 1 em relação ao método 2 .

- O alto valor do desvio padrão no caso do método 1 e 2 para Ribeirão Preto relativiza (minimiza a importância do resultado) o valor obtido para a redução dos acidentes. 
Em todas as cidades, observa-se uma redução do número de acidentes nos semáforos após a colocação de grupo focal com informador de tempo na via principal: São Carlos: método $1=18$ (34\%) e método $2=24,60$ (45\%); Ribeirão Preto: método $1=1(5 \%)$ e método 2 = 3,39 (16\%); Piracicaba: método $1=19$ (35\%).

Dessa forma, pode-se dizer que a mudança de grupo focal com informador de tempo na via principal trouxe significativo benefício para a segurança no trânsito nas

interseções. Á luz dos resultados do método 1 infere-se que o grupo focal modelo 3 empregado em Piracicaba (redução de 35\%) e o modelo 1 empregado em São Carlos (redução de 34\%) estão num patamar de eficiência maior em relação ao modelo 2 empregado em Ribeirão Preto (redução de 5\%).

\subsection{Observações importantes}

A quantidade de acidentes numa interseção semaforizada é influenciada, sobretudo, pelas características da interseção e do semáforo.

Com relação ás características da interseção, os aspectos mais relevantes são: geometria, localização, fluxo de veículos, etc.

No tocante às características do semáforo, podem ser destacados os seguintes aspectos principais:

- Visibilidade do grupo focal: que sofre influência da posição do grupo focal (na lateral da via ou projetado sobre a mesma), do emprego ou não de anteparo e das características do mesmo (quanto maior o tamanho do anteparo, mais vísivel, principalmente a noite, se dotado de orla refletiva; etc.), do tamanho 
dos focos (se de $300 \mathrm{~mm}$ ou de $200 \mathrm{~mm}$ ), da luminosidade das luzes dos focos (se lâmpadas comuns ou LED - Light Emission Diod), da existência de sinais luminosos adicionais, como acontece nos grupos focais com indicação do tempo restante, etc.

- Emprego, ou não, de vermelho total e duração do mesmo.

- Duração do amarelo.

- Existência ou não de aviso prévio da mudança da luz vermelha para a luz verde (que não é feito nos grupos focais convencionais, mas é feito nos grupos focais com informação de tempo), também do verde para o vermelho (que nos grupos focais convencionais é feito por intermédio da luz amarela).

- Padrão do grupo focal: os usuários reagem de maneira automática e com maior eficência à sinalização a que estão acostumados, ou seja, ao padrão legal, que corresponde ao grupo focal convencional.

Esses fatos são aqui colocados pelas seguintes razões:

- Há uma grande diferença entre os resultados da estimativa da redução do número de acidentes nas cidades de São Carlos (34\%) e Piracicaba (35\%) em relação à cidade de Ribeirão Preto (5\%) com a substituição de grupos focais convencionais por grupos focais com indicação de tempo na via principal.

- Nos modelos de grupos focais com informador de tempo empregados nas cidades de Ribeirão Preto e Piracicaba, a estrutura básica dos grupos focais convencionais é mantida (conjunto de luzes normais acesas ou apagadas), 
sendo o tempo restante fornecido por intermédio de informação situada ao lado dos focos convencionais; o que faz com que esses modelos se aproximem mais do padrão convencional. No modelo empregado em São Carlos, isso não acontece, pois o tempo restante é sinalizado diretamente pelo conjunto de luzes que constituem os focos e que vão se apagando, ainda que o foco verde/vermelho situado no extremo inferior seja mantido aceso; isso significa que esse modelo se afasta mais do padrão convencional.

A luz dessas observações, ainda que tenham sido verificados ganhos significativos com a mudança de grupo focal com informador de tempo na via principal em todas as cidades e, portanto, modelos de grupo focal, cabe colocar se isso não se deve ao aumento do tamanho do grupo focal, o que poderia ser obtido com o simples emprego de anteparos maiores nos grupos focais convencionais.

Também o emprego de orla refletiva poderia, a princípio, compensar o aumento da área luminosa, sobretudo à noite, promovido pelo informador de tempo dos grupos focais dotados dessa característica.

Mais, no caso da cidade de São Carlos, a maioria dos grupos focais convencionais se situavam originariamente nas laterais da via principal e, quando foram substituídos por grupos focais com informação de tempo, passaram a ser projetados sobre a via.

Em vista do exposto, a dúvida que fica é se o ganho de segurança, e também de estética, dos grupos focais com indicação de tempo, não poderia ser obtido a custos 
muito menores com o emprego de focos maiores (quando for o caso), com focos dotados de LED, com anteparos grandes dotados de orla refletiva e com grupos focais posicionados sobre a via (quando for o caso). 


\section{CONSIDERAÇŨES FINAIS}

Nos últimos tempos, tem crescido bastante o emprego de semáforos dotados de grupos focais com informação do tempo de verde/vermelho restante - e são vários os modelos utilizados. As empresas fabricantes afirmam que esses equipamentos aumentam a capacidade e reduzem a acidentalidade nas interseções semaforizadas, além de apresentarem uma estética mais adequada.

Não resta dúvida que alguns modelos de grupo focal com informador de tempo tem aparência mais moderna e esteticamente mais adequada do que os modelos convencionais de grupos focais.

Há três questões, no entanto, sobre o emprego desses novos modelos de grupos focais:

- Não há autorização legal por parte do DENATRAN (Departamento Nacional de Trânsito) para o emprego de grupo focal semafórico com indicação de tempo; dessa forma, a responsabilidade jurídica no caso de acidentes é de alçada das Prefeituras, pois o equipamento não se enquadra no padrão nacional previsto pelo DENATRAN.

- Não se sabe se, efetivamente, há um aumento da capacidade de passagem dos veículos pela interseção semaforizada quando se utiliza grupo focal com informação de tempo. 
- Da mesma forma, não se sabe se, efetivamente, há melhoria da segurança viária na interseção, ou seja, redução da acidentalidade no trânsito; algumas cidades noticiam que a segurança melhorou; outras que piorou.

Neste trabalho foi comparado o desempenho, em termos de capacidade e segurança, de interseções semaforizadas dotadas de grupos focais convencionais com outras dotadas de grupos focais com informação do tempo de verde/vermelho restante na via principal (a via secundária continuava com grupo focal comum).

Foram analisados três modelos distintos quanto à maneira em que é realizada a informação do tempo de verde/vermelho restante: por intermédio de focos com tamanho normal com luzes que vão se apagando acima do foco usual que se mantém aceso (como empregado em São Carlos), com focos de tamanho pequeno com luzes que vão se apagando situadas ao lado de focos padrões (como empregado em Ribeirão Preto) e com visor contendo informação digital ao lado de focos padrões (como empregado em Piracicaba).

No tocante à eficiência operacional da interseção semaforizada, os resultados obtidos no estudo mostram que não há, praticamente, alteração no valor da capacidade da passagem de veículos pela interseção semaforizada quando se substitui grupo focal comum por grupo focal com informador de tempo. Nas hipóteses consideradas no estudo, as diferenças de capacidade situam-se no intervalo: $-2,39 \% \mathrm{a}+1,71 \%$.

Quanto à segurança, a substituição de grupo focal convencional por grupo focal com informador de tempo na via principal trouxe significativa redução do número de 
acidentes. Os valores de redução do número de acidentes obtidos no estudo foram os seguintes: modelo de grupo focal 1 (empregado em São Carlos) $=35 \%$, modelo de grupo focal 2 (empregado em Ribeirão Preto) $=5 \%$, modelo de grupo focal 3 $($ empregado em Piracicaba $)=34 \%$,

No entanto, a dúvida que fica é se o ganho de segurança - e, em grande medida, também de estética - dos grupos focais com indicação de tempo não poderia ser obtido a custos muito menores com o emprego de focos maiores (quando for o caso), com focos dotados de LED (Light Emission Diod), com anteparos grandes dotados de orla refletiva e com grupos focais posicionados sobre a via (quando for o caso).

As limitações deste trabalho, sobretudo quanto à análise da segurança, remetem a necessidade de estudos mais adequados e mais aprofundados no futuro sobre a questão. Recomenda-se, no entanto, tomar como referência os valores obtidos nesta pesquisa, bem como as observações feitas. 


\section{REFERÊNCIAS BIBLITGRÁFICAS}

ABETRANS - Associação Brasileira de Empresa do Setor de Trânsito Prefeitura retira semáforos com temporizador das ruas da capital. Disponível em: http://www.abetrans.org.br/noticias/index.php?C=4317\&PHPSESSID=f91d47fcba8bb f. Acesso em: 21/09/2009

AKÇELIK, R. (1981). Traffic Signals - Capacity and Timing Analysis. Australian Road Research Board Ltd. Research Report no 123. 109 p.

BARBUTO. L.S. (1994). Desrespeito aos Semáforos. NOTAS TÉCNICAS 164/94. CET /SP.

BECK, R.V.; JACQUES, M.A.; ANDRADE N.P. (1996). Avaliação do impacto do semáforo com informador auxiliar de tempo sobre a capacidade das interseções. In: X CONGRESSO DE PESQUISA E ENSINO EM TRANSPORTE, 
1996, Brasília. X CONGRESSO DE PESQUISA E ENSINO EM TRANSPORTE, 1996. P. 623-631.

BEZERRA, B. S. (2007). Semáforos: Gestão técnica, Percepção do Desempenho, Duração dos Tempos. 235p. Tese (Doutorado) - Escola de Engenharia de São Carlos, Universidade de São Paulo, São Carlos.

BRASIL - Código de Trânsito Brasileiro. (2008). Instituído pela Lei no 9.503, de 23-9-97 - 3를 edição - Brasiléia: DENATRAN. 232 p.:Il.

CUCCI NETO, J. (1999). Projeto Semafórico: legislação, arranjo físico e sinalizações relacionadas.

Disponível em:<HTTP://www.meusite.mackenzie.com.br/professor_cucci/texto2.pdf. Acesso em: $06 / 08 / 2009$

DNER, (1971). Manual inter-americano de sinalização rodoviária e urbana Dispositivos para controle de trânsito. Rio de Janeiro.

DENATRAN - Departamento Nacional de Trânsito. Disponível em: <http://www.denatran.gov.br/frota.htm>. Acesso em: 10/09/2010 
EIZENBERG, S. Segurança na Temporização. Instituto Nacional de Segurança no Transito, São Paulo. (apostila).

ELVIK, R.; VAA, T. (2004). The handbook of road safety measures. Editora ELSEVIER

FEERAL HIGHWAY ADMINISTRATION - Manual on Uniform Traffic Control Devices (MUTCD) - for streets and Highways, (2003). Washington, D.C., E.U.A., 2003

FERRAZ, A. C. P. (2005). Tráfego Rodoviário. Escola de Engenharia de São Carlos, Universidade de São Paulo, São Carlos,. (apostila)

FERRAZ, A. C. P.; RAIA JUNIOR, A. A.; BEZERRA, B. S. (2008). Segurança no trânsito. São Carlos: NEST.

FORNACIARI, I. A. (2010). Investigação no campo da programação semafórica. Dissertação (Mestrado em Engenharia de Transportes) - Escola de Engenharia de São Carlos, Universidade de São Paulo, São Carlos, 
GONÇALVES. J. E. L. (1980). As Funções da Sinalização de Trânsito. NOTAS TÉCNICAS - 60. CET / SP.

GONÇALVES, J. E. L. (1980). A Importância da Sinalização Uniforme. NOTAS TÉCNICAS - 062 / 80. CET / SP.

HAUER, E. (1997). Observation Before - After studies in road safety Estimating the effect of highway and traffic engineering measures on road safety. Departament of Civil Engineering University of Toronto.

HCM, Highway Capacity Manual, 4 ed., Transportation Research Board, Washington D.C., 2000.

IBGE - Instituto Braliseiro de Geografia e Estatística. Disponível em: <http://www.ibge.gov.br/cidadesat/topwindow.htm?1>. Acesso em 10/09/2010

JORNAL DO FORUM. (2006). Semáforo com informador de tempo. Publicação do Fórum Mineiro Gerenciadores de Transportes e Trânsito. №37.Disponível em: <http://servicosbhtrans.pbh.gov.br/bhtrans/figuras/jornal\%20do\%20forum\%20agosto \%202006.pdf> Acesso em: 06/08/2009 
Manual de Semáforos. 2ª Ed., Brasília, DENATRAN. (1984). 172 p., II. (Col. Serviços de Engenharia).

Disponível

em:

http://meusite.mackenzie.com.br/professor_cucci/ManualSemáforos.pdf. Acesso em $13 / 08 / 2009$

Manual de Sinalização Semafórica - Critérios de Programação. (2002). Companhia de Engenharia de Tráfego - Departamento de Desenvolvimento de Recursos Humanos - DDR.

ROESS, R.P.; PRASSAS, E.S.; MCSHANE, W.R. (2004). Traffic Engineering. Third Edition Prentice Hall. New Jersey, (2004).

SETTI, J.R.A. (2002). Tecnologia de Transportes. Material didático para uso exclusivo dos alunos da EESC-USP. Versão preliminar, de divulgação restrita. Universidade de São Paulo - Escola de Engenharia de São Carlos. São Carlos.

VASCONCELOS, Eduardo Alcântara. (1952). Pesquisas e levantamentos de tráfego. São Paulo, Companhia de Engenharia de Tráfego. (Boletim Técnico CET, 31). Disponível em: <http://meusite.mackenzie.com.br/professor_cucci/aulas.htm>. Acesso em 13/08/2009 